Illinois State University

ISU ReD: Research and eData

Theses and Dissertations

$4-19-2015$

\title{
Effects of Physical Characteristics of Urban Storm Sewersheds on Water Quality in Bloomington, IL
}

Alicia Terese O'Hare

Illinois State University, aliciatohare@gmail.com

Follow this and additional works at: https://ir.library.illinoisstate.edu/etd

Part of the Geochemistry Commons, and the Geographic Information Sciences Commons

\section{Recommended Citation}

O'Hare, Alicia Terese, "Effects of Physical Characteristics of Urban Storm Sewersheds on Water Quality in Bloomington, IL" (2015). Theses and Dissertations. 399.

https://ir.library.illinoisstate.edu/etd/399

This Thesis is brought to you for free and open access by ISU ReD: Research and eData. It has been accepted for inclusion in Theses and Dissertations by an authorized administrator of ISU ReD: Research and eData. For more information, please contact ISUReD@ilstu.edu. 


\title{
EFFECTS OF PHYSICAL CHARACTERISTICS OF URBAN STORM SEWERSHEDS ON WATER QUALITY IN BLOOMINGTON, IL
}

\author{
Alicia T. O’Hare \\ 111 Pages \\ August 2015 \\ Increasing urbanization has consequences for surface water quality. Stormwater is \\ a large component of urban water degradation that is poorly understood. Precipitation is \\ quickly transported via underground pipes, from the land to the stream without \\ necessarily following water's natural flow path. Studies have correlated ponds with \\ improved water quality and impervious surface cover with degraded water quality. \\ However, other physical characteristics within a storm sewershed including the presence \\ of sump pumps, area and pipe miles may also affect the stormwater quality. We chose 18 \\ storm sewer systems in Bloomington, Illinois. Using geographic information systems \\ techniques, we delineated the area of these storm sewersheds and determined the physical \\ characteristics of each. In addition, we measured $\mathrm{pH}$, temperature, conductivity, \\ dissolved oxygen, chloride, nitrate, phosphate, and total suspended solids. Relationships \\ and differences among the physical characteristics and water quality were determined \\ using correlation and ANOVA analyses. We found that the presence of a pond \\ significantly lowered total suspended solids and the greater the length of pipe the lower \\ the concentration of nitrate. This research could contribute to how storm sewers are built \\ and retrofitted in the future to decrease the water quality degradation from storm events.
}



EFFECTS OF PHYSICAL CHARACTERISTICS OF URBAN STORM SEWERSHEDS

ON THE WATER QUALITY IN BLOOMINGTON, IL

ALICIA T. O'HARE

A Thesis Submitted in Partial

Fulfillment of the Requirements

for the Degree of

MASTER OF SCIENCE

Department of Geography-Geology

ILLINOIS STATE UNIVERSITY

2015 
ProQuest Number: 1599426

All rights reserved

INFORMATION TO ALL USERS

The quality of this reproduction is dependent upon the quality of the copy submitted.

In the unlikely event that the author did not send a complete manuscript and there are missing pages, these will be noted. Also, if material had to be removed, a note will indicate the deletion.

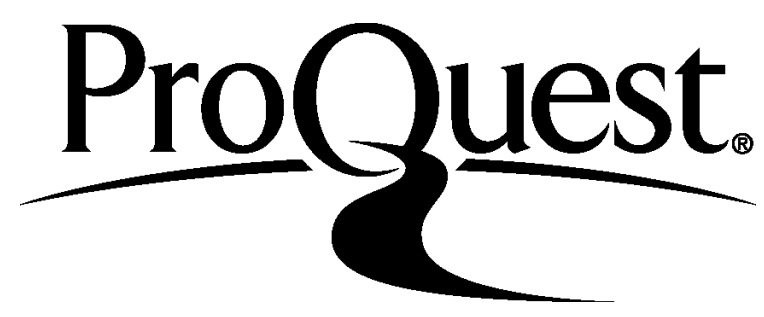

ProQuest 1599426

Published by ProQuest LLC (2015). Copyright of the Dissertation is held by the Author.

All rights reserved.

This work is protected against unauthorized copying under Title 17, United States Code Microform Edition (C) ProQuest LLC.

ProQuest LLC.

789 East Eisenhower Parkway

P.O. Box 1346

Ann Arbor, MI 48106 - 1346 
(C) 2015 Alicia T. O’Hare 
EFFECTS OF PHYSICAL CHARACTERISTICS OF URBAN STORM SEWERSHEDS ON THE WATER QUALITY IN BLOOMINGTON, IL

\author{
ALICIA T. O'HARE
}

COMMITTEE MEMBERS:

Catherine M. O’Reilly, Chair

Rex J. Rowley

John C. Kostelnick 


\section{ACKNOWLEDGMENTS}

I first want to thank my committee members for all of their support. Catherine O’Reilly was wonderfully supportive in her mentorship and guidance. Rex J Rowley and John Kostelnick offered their technical expertise freely and willingly. Especially, thanks to Kevin Kothe for taking time out of his busy schedule at the City of Bloomington to support this project by supplying insight and advice. Additionally, I would like to thank Troy Olson from the City of Bloomington and Bill Jackson from McGIS for supplying data and advice.

I would also like to thank the Illinois Groundwater Association for funding this project financially. Thank you to the Hedgewood Park Homeowners Association for granting me access to sample sites.

Generous thanks also go to those that came out into the rain and mud to collect and process samples: Paula Pryor, Gwen Gates, David Cord, and Kelly Sanks. Also thank you to Brian Grebliunas, Dr. Bill Perry and Victoria Bertolami for their assistance with laboratory analysis.

Finally, I would like to thank my husband, Sean O'Hare, for his unyielding support, confidence and wonderful graphic design insight.

A.T.O. 


\section{CONTENTS}

\section{Page}

ACKNOWLEDGMENTS

CONTENTS

TABLES

FIGURES

CHAPTER

I. INTRODUCTION 1

Literature Review 1

Hypotheses $\quad 5$

$\begin{array}{ll}\text { Study Area and Project Overview } & 6\end{array}$

II. DETERMINING THE PHYSICAL CHARACTERISTICS OF STORM SEWERSHEDS WITH GIS 9

$\begin{array}{lr}\text { Introduction } & 9\end{array}$

Study Area $\quad 11$

$\begin{array}{ll}\text { Methodology } & 13\end{array}$

Results and Discussion $\quad 20$

Conclusions and Future Work 33

Possible Applications $\quad 35$

III. EFFECTS OF PHYSICAL CHARACTERISTICS OF URBAN STORM SEWERSHEDS ON WATER QUALITY

Introduction $\quad 36$

Study Region and Study Period Overview $\quad 38$

$\begin{array}{ll}\text { Methods } & 40\end{array}$

Storm Sewershed Characterization $\quad 40$

Precipitation and Discharge $\quad 42$

Stormwater Collection and Analysis $\quad 43$

Statistical Analysis $\quad 44$ 
Results 45

Concentrations $\quad 45$

Mass Flux $\quad 51$

Discussion $\quad 52$

Conclusions and Implications $\quad 56$

$\begin{array}{ll}\text { REFERENCES } & 58\end{array}$

APPENDIX A: Storm Sewershed Maps, Locations and Descriptions 62

APPENDIX B: Storm Sewershed Characteristics 101

APPENDIX C: Raw Chemistry Data 104 


\section{TABLES}

Table $\quad$ Page

1. Sources and Details of GIS Data Used in this Project 14

2. Various Snap Distances Used to Determine Pour Points 16

3. Zoning Classification Groupings 19

4. A Summary of Physical Characteristics of the Storm Sewersheds in this Study

5. Precipitation Magnitude When Samples Were Taken 43

6. Mean Concentrations by Precipitation Magnitude 46

7. Mean Concentrations by Season 47

8. Results of Our a priori Hypotheses 57 


\section{FIGURES}

Figure $\quad$ Page

$\begin{array}{ll}\text { 1. Site Locations } & 7\end{array}$

2. GIS Workflow 18

3. Storm Sewersheds may be Non-Continuous 21

4. A Long and Skinny Storm Sewershed 22

5. A Square Storm Sewershed 23

6. A Storm Sewershed with a Flood Route 25

7. A Storm Sewershed with an Underestimated Area 26

8. Flow Accumulation Lines Along Road Curbs 29

9. Flow Accumulation Lines Through a Building 30

10. Correlations of Physical Characteristics 32

11. Sump Pumps may be Outside Storm Sewershed Boundaries 33

12. An Example of a Storm Sewer System 37

13. Storm Sewersheds with Ponds had Better Stormwater Quality 48

14. Chloride Concentrations were Positively Correlated with Impervious $\begin{array}{ll}\text { Surface Cover } & 49\end{array}$

15. Total Suspended Solid Concentrations were Positively Correlated with Percent Road Area $\quad 50$

16. Storm Sewersheds with Sump Pumps had Better Stormwater Quality 51 


\section{CHAPTER I \\ INTRODUCTION}

\section{Literature Review}

Increasing urbanization has consequences for surface water quality. The world's urban population continues to rise at a projected annual rate of $1.8 \%$ for the next 20 years (Cohen, 2003). In comparison, the global population growth rate is only $1.22 \%$ (Cohen, 2003). There are predictable responses of streams to urban development (Walsh et al., 2005a) including increased nutrient and contaminant concentrations (Meyer et al., 2005; Walsh, 2005a).

The majority of contaminants enter streams and rivers as a result of stormwater runoff (Walsh et al., 2005a; EPA, 1999). Rain is relatively pure (Shertzer, et al, 1998) so most contaminants likely come from the surface. The water flows across the surface, enters a storm drain and travels through a pipe to the river. As a result, hydrological processes that take years in a natural watershed may only take hours in cities (Bloschl \& Sivapalan, 1995). Hydrographs are most often used during storm events to observe peak flow by plotting stream discharge versus time. In such a hydrography, typically there is a delay between when the storm begins and when increased stream flow is observed. In urban environments this delay is decreased and the peak flow is higher (Walsh et al., 2012). 
Run-off occurs when the rate of precipitation exceeds the rate of infiltration. In urban settings there are many surfaces where infiltration possibility is zero (parking lots, roads, sidewalks etc.) making runoff occur immediately (Walsh et al., 2012). Thus, urban environments experience runoff levels eight times more often than undeveloped watersheds (Gallo et al, 2013). This means even small storms that would not normally create runoff will send polluted water to receiving waters (Walsh et al., 2012). In addition, an impervious surface will produce up to sixteen times more runoff than a pervious area (CWP and MDDEWMA, 2000).

Impervious surface cover is strongly correlated with the degradation of urban streams. Additionally, the percentage of impervious surface cover (\%ISC) is indirectly related to the time it takes for stormwater runoff to reach the stream (Walsh et al., 2005b; Cantone \& Schmidt, 2011). Rivers in watersheds with impervious surface cover greater that $5 \%$ have a significantly greater concentration of nitrate and chloride than reference streams (Cunningham et al., 2009). Essentially, higher \% ISC increases the efficiency of runoff transportation of contaminants (Hatt et al. 2004). Questions remain about the relationship between water quality and increasing \% ISC.

Nitrogen is now more abundant in urban areas than undeveloped ecosystems (Grimm et al., 2005). Increased nutrients are a result of the increased supply and decreased retention (Grimm et al., 2005). In one recent study, watersheds with storm drains had higher concentrations of nutrients than forested watersheds (Kaushal and Belt, 2012).

It is reasonable to expect that a detention or retention pond will improve water quality (Herrmann, 2012). Detention ponds are basins that dry out in between storm 
events, while a retention pond continuously holds water. Detention ponds and retention ponds, whether intentionally designed to or not, will provide some water quality control measures (Marsalek, 2002). Originally designed to reduce the peak flows during a storm event, ponds will provide treatment through the settling of sediment (Tixier, 2001; Marsalek, 2002). A 2.5-year study by Herrmann (2012) showed nutrient reductions of $43 \%$ for nitrogen and $35 \%$ for phosphorous.

Infrastructure itself can contribute to changes in water quality in urban stream systems. Concrete ditches and PVC pipes that transport stormwater to rivers may raise $\mathrm{pH}$ and contribute calcium and bicarbonate to the stream (Davies et al, 2010). Rainwater collected from a roof that had a $\mathrm{pH}$ of 4.8 was raised to 7.9 and bicarbonate went from $0.5 \mathrm{mg} / \mathrm{L}$ to $17.3 \mathrm{mg} / \mathrm{L}$ after only 100 minutes of concrete contact; all other major ions showed an increase in concentration as well (Davies et al, 2010). If concrete lined pipes and ditches are used to transport stormwater to a stream one might expect changes in some components of the water chemistry.

Storm events are variable and unpredictable. Prior to a storm's occurrence there is no way to determine its exact behavior (Sheng et al., 2008). The frequency and magnitude of previous storms can, of course, affect the available contaminants for later storms. Brodie (2007), for example, found that the load of non-coarse particles during a storm was related to the characteristics of previous storm events. It is often assumed that the highest concentrations will occur in the beginning of the storm in a period called first flush. However, Ren et al. (2008) found that in light rain concentrations varied throughout the event and runoff from road did not always show peak concentrations at the beginning of an event. 
One challenge in determining the effect of storm sewersheds is the actual process of delineating the contributing area. Storm sewersheds are a small-scale feature that high resolution elevation data is required. However, fine scale light detection and ranging data (LiDAR) can have a great deal of noise as a result of vegetation and other surface features, which can ultimately result in incorrect drainage paths (Goulden et al., 2014). In addition, most drainage paths are designed to flow along the sides of roads. In an effort to correctly model this in digital elevation models (DEMs), road burning has been used in past. This process lowers the elevation of the road to ensure run-off travels to it (Elgy et al, 1993). Another method used routed determination based on physical characteristics of blocks within the urban landscape and directed flow to the nearest down slope inlet (Green and Cruise, 1995).

Storm sewersheds are different than watersheds. Watersheds are defined as the area in which water drains to a single point. Storm sewersheds have many pour points that are connected by underground outlet. In addition the outlet of the storm sewer system is not necessarily considered a pour point. Given such ambiguities, for this project, we developed a working definition of storm sewershed. A storm sewershed is the land area from which stormwater drains before traveling through a sewer system and discharging to a surface water body.

The purpose of this thesis was to determine what characteristics of storm sewershed affect water quality. The characteristics we expected to change water quality; presence of a retention pond, sewer miles, sewer density, percent impervious surface cover (\%ISC) storm sewershed area, presence of sump pumps, and zoning. 


\section{Hypotheses}

We hypothesized that the presence of a retention or detention pond in a storm sewershed will improve water quality. Ponds increase the amount of time it takes for water to reach receiving waters (Walsh et al., 2005b; Tixier, 2001). The delay allows for settling of solids and nutrient uptake (Herrmann, 2012). Primary indicators used to verify this hypothesis were nutrients and total suspended solids.

We hypothesized that as sewer miles increase, water quality will be more degraded. Almost all stormwater pipes in Bloomington, Illinois, are Portland cement concrete pipe (PCCP) (pers. comm., Kevin Kothe). The more time stormwater is in contact with concrete piping the more ions, such as calcium and bicarbonate, the water will pick up. (Davies et al., 2010). Pipes also connect impervious surfaces leading to greater water quality degradation (Walsh et al., 2005b). Primary indicators used to verify this hypothesis were $\mathrm{pH}$ and total suspended solids.

We hypothesized that as sewer density increases water quality will be less degraded. Water picks up pollutants as it travels over the surface (Walsh et al., 2005b). If sewer systems are denser then water will spend less time on the surface. Primary indicators used to verify this hypothesis were nitrate, phosphate, ammonium and total suspended solids.

We hypothesized that as \%ISC increases water quality will be more degraded. Percent ISC has been correlated with increased nutrients (Walsh et al, 2005a; Cunningham et al., 2009). Primary indicators used to verify this hypothesis were nitrate, phosphate and chloride concentrations. 


\section{Study Area and Project Overview}

This study was conducted in Bloomington, Illinois. The City of Bloomington is located approximately 125 miles southwest of Chicago. Immediately north of Bloomington is the Town of Normal. The two municipalities are so close they are locally known as the "Twin Cities." The combined area of the cities is over 90 square kilometers. The combined population of the two cities is approximately 125,000 (US Census, 2010).

A stream, Sugar Creek, flows along the border of Bloomington and Normal (Figure 1). All of the sites in this study drain into Sugar Creek. The storm sewer systems included in this study were primarily owned and maintained by the City of Bloomington (pers. comm., Kevin Kothe). Three systems also had connections with private owners and one system was entirely private. It should also be noted here that some storm sewer lines, whether public or private, may not appear on maps as underground features can be easily overlooked or forgotten.

Geologically, the city of Bloomington is located on an end moraine of the Wisconsin Glaciation. The geology of the area is primarily glacial till of the Wedron Formation composed of pebbly clay till (Weibel and Nelson, 2009). There is also a thin alluvial deposit (Stiff, 2000) along Sugar Creek.

The majority of the storm sewer system in Bloomington was built between 1950 and 1980, making the system, at least in part, slightly older than the national average of 45 years (Chang \& Hernandez, 2008). Much of this system requires replacement and expansion. The Municipal Separate Storm Sewer System (MS4) regulates the city of Bloomington with a permit administered by the Illinois Environmental Protection 


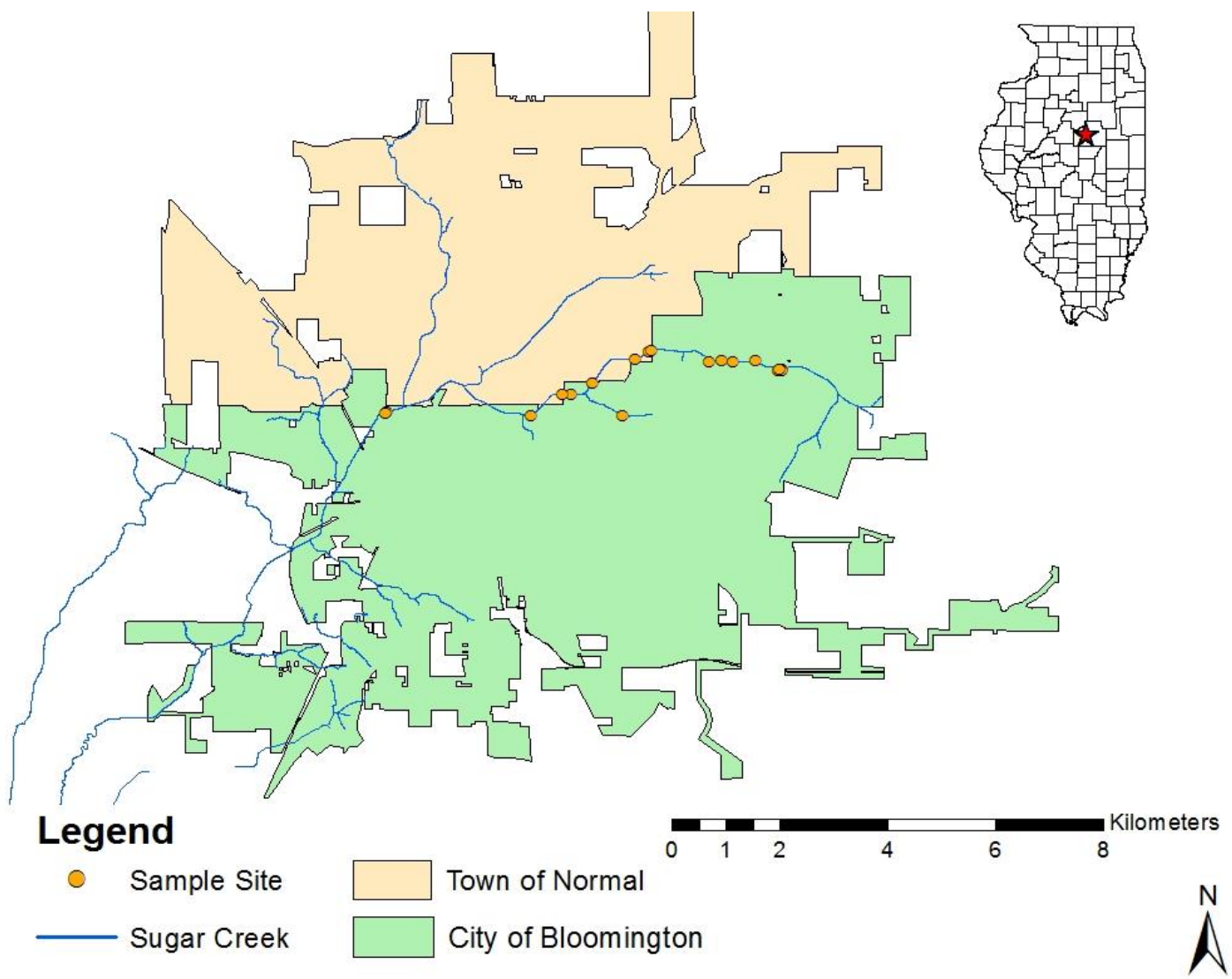

Figure 1. Site Locations. Locations at which storm water sampling took place. Samples were taken at a storm sewer outlet prior to the water reaching the stream

Agency. The city of Bloomington has committed to make efforts over twenty years to improve stormwater quality (City of Bloomington, 2013). The pipes were made of PCC, clay brick or polyvinyl chloride (PVC) (pers. comm., Kevin Kothe) and vary in size at their outlets from $30 \mathrm{~cm}$ to $364 \mathrm{~cm}$. The storm sewer system studied is primarily gravity fed; except for sump pumps.

Between the months of May 2014 and February 2015 we sampled eighteen storm sewer systems for water quality during flow events. This study was limited in that only one sample was collected from the outflow of each storm sewershed during each event. We aimed to take a sample near the beginning of each storm event, but it was not possible to know exactly at what point in the hydrograph a sample was taken. However, 
we assumed that the physical characteristics of each storm sewershed would affect the water quality in a similar manner throughout the entire hydrograph. 


\section{CHAPTER II}

\section{DETERMINING THE PHYSICAL CHARATERISTICS \\ OF STORM SEWERSHEDS WITH GIS}

\section{Introduction}

Storm sewer systems are an important aspect of city design; they prevent flooding by quickly transporting runoff to a waterway (City of Bloomington, 2013). Growing concern about the health of urban streams has led scientists to consider the chemical composition of storm runoff (Gallo et al., 2013; Meyer et al., 2005; Walsh et al, 2005a). Runoff water chemistry is dependent on the surfaces over which that water travels (Choe et al, 2002; Chow and Yusop, 2014). If the area that contributes runoff can be categorized then we can understand more about patterns in runoff chemistry and potentially improve water quality as we build new and retrofit existing storm sewers. The purpose of this portion of the project is to explain and critique a method of delineating storm sewersheds using simplified methods and readily available data. This of course, will then allow us to determine the characteristics of those sewersheds.

The path of stormwater through a storm sewer system is different than in an undisturbed watershed (Bloschl \& Sivapalan, 1995). Watersheds are defined as the land area over which water flows before draining to a single point. A storm sewershed is the land area over which stormwater drains before traveling through a sewer system and discharging to asurface water body or stream. A storm sewershed is therefore different in 
that it has multiple pour points that are separate on the land surface but connected via underground pipes. As a result precipitation that lands in one watershed may be transported to another watershed via the underground network (Crimmens, 2006). Natural watersheds have channels that are in constant flux due to erosion and deposition, whereas the channels in urban environments are designed and held constant by city engineers. Undisturbed stream channels and watersheds are connected to the groundwater, but impervious surface cover (ISC) in urban systems reduces the opportunity for storm water to enter the groundwater system (Arden et al., 2014). Once stormwater reaches an impervious surface it is unlikely that it will have another opportunity to infiltrate prior to being discharged to the stream.

In urban environments some land features such as buildings and roads direct stormwater flow. Past studies have manipulated their digital elevation model (DEM) in an effort to obtain the best delineation of the contributing area. One technique called burning forces flow away from buildings and towards roads (Elgy, 1993). Another technique uses breaklines to prevent flow from crossing barriers (Graham, 2012). The downside of using such techniques is that alteration of the DEM for an entire city could take a great deal of an analyst's time and effort. As technology for generating DEMs advances their sensitivity increases and achieving success with delineating sewersheds with less manipulation becomes more possible. Light detection and ranging (LiDAR)derived elevation sets have finer resolution that other DEMs. LiDAR data often has cell sizes less than 1 meter while common DEMs may have cells of 5 meters or 10 meters. We chose the finest scale resolution ( $0.76 \mathrm{~m}$ cell size) LiDAR available for our area. However, LiDAR is not without its limitations, it can have a great deal of noise due to the 
presence of vegetation and other surface features (Goulden et al, 2014). The LiDAR then goes through a filtering process to remove this noise and smooth the landscape. The resulting dataset, called a "bare earth model," has far less error; it represents the topography as if there was no vegetation or structures on the land surface. The small scale of storm sewershed (less than $2 \mathrm{~km}^{2}$ in most cases) requires fine enough resolution on the DEM to detect subtle changes in topography within a small area.

The primary objective of this portion of the project was to create a model to delineate the boundaries of storm sewersheds using geographic information systems (GIS) and to do so with minimal manipulation of the initial datasets. With such a delineation completed, we then determined for each sewershed the percent impervious surface cover (\%ISC), primary zoning, and inlet density. We also observed the presence or absence of ponds and sump pumps in storm sewersheds. We completed this analysis for eighteen storm sewer systems in Bloomington, Illinois, sampled for this study. We used statistical analysis to determine any correlations between physical characteristics.

\section{Study Area}

This study was conducted in Bloomington, Illinois. The City of Bloomington is located approximately 125 miles southwest of Chicago. Immediately north of Bloomington is the Town of Normal. The two municipalities are so close they are locally known as the "Twin Cities." The combined area of the cities is over 90 square kilometers. The combined population of the two cities is approximately 125,000 (US Census, 2010).

A stream, Sugar Creek, flows along the border of Bloomington and Normal (Figure 1). All of the sites in this study drain into Sugar Creek. The storm sewer systems included in this study were primarily owned and maintained by the City of Bloomington. 
Three systems also had connections with private owners and one system was entirely private. It should also be noted here that some storm sewer lines, whether public or private, may not appear on maps as underground features can be easily overlooked or forgotten.

Geologically, the city of Bloomington is located on an end moraine of the Wisconsin Glaciation. The geology of the area is primarily glacial till of the Wedron Formation composed of pebbly clay till (Weibel and Nelson, 2009). There is also a thin alluvial deposit (Stiff, 2000) along Sugar Creek.

The majority of the storm sewer system in Bloomington was built between 1950 and 1980, making the system, at least in part, slightly older than the national average of 45 years (Chang \& Hernandez, 2008). Much of this system requires replacement and expansion. The Municipal Separate Storm Sewer System (MS4) regulates the city of Bloomington with a permit administered by the Illinois Environmental Protection Agency. The city of Bloomington has committed to make efforts over twenty years to improve stormwater quality (City of Bloomington, 2013). The pipes were made of PCC, clay brick or polyvinyl chloride (PVC) (pers. comm., Kevin Kothe) and vary in size at their outlets from $30 \mathrm{~cm}$ to $364 \mathrm{~cm}$. The storm sewer system studied is primarily gravity fed; except for sump pumps.

The eighteen storm sewersheds we analyzed were chosen in an effort to maximize the variability of their characteristics. We used a combination of aerial imagery and initial data sets to select storm sewer systems to study. Size and shape were the primary criteria utilized in this selection process. We wanted to analyze a range of size of systems and so, we judged the area on the length the pipe in a storm sewer system. Our choices based on 
shape narrowed down the possible storm sewer systems, we attempted to choose some that were long and skinny and others that were more square-shaped. Our final criteria for selection was a visual determination of zoning, we tried to include several storm sewer systems that drained different zoning classifications. In other words, we chose certain storm sewer systems because they drain residential areas and others because they draining parking lots and commercial areas.

\section{Methodology}

Characterization of storms sewersheds is, of course, dependent upon knowing the land area that contributes water to the storm sewer system through a system of inlet drains to underground pipes. It required detailed large scale vector datasets describing the area (e.g. zoning and ISC) in addition to the DEM. Examples of such characteristics include percent ISC and inlet density. The procedure we created to determine and characterize the area contributing to storm sewers was implemented in a GIS environment. Initial data layers included elevation, storm sewer networks, inlets, impervious surface cover, zoning, ponds and aerial imagery (Table 1).

The elevation dataset used was a LiDAR-derived raster dataset with a cell size of $0.76 \mathrm{~m}$. The horizontal accuracy was 1 meter and the vertical accuracy was 0.4 meters. The sewer system and provided inlets had horizontal accuracy of approximately $1.5 \mathrm{~m}$. Additional inlets were generated manually in parts of the city that were built since the inlet layer was created. This was accomplished via interpretation of aerial imagery, which was flown in 2014 with a spatial resolution of $7.5 \mathrm{~cm}$. The LiDAR data set covers 


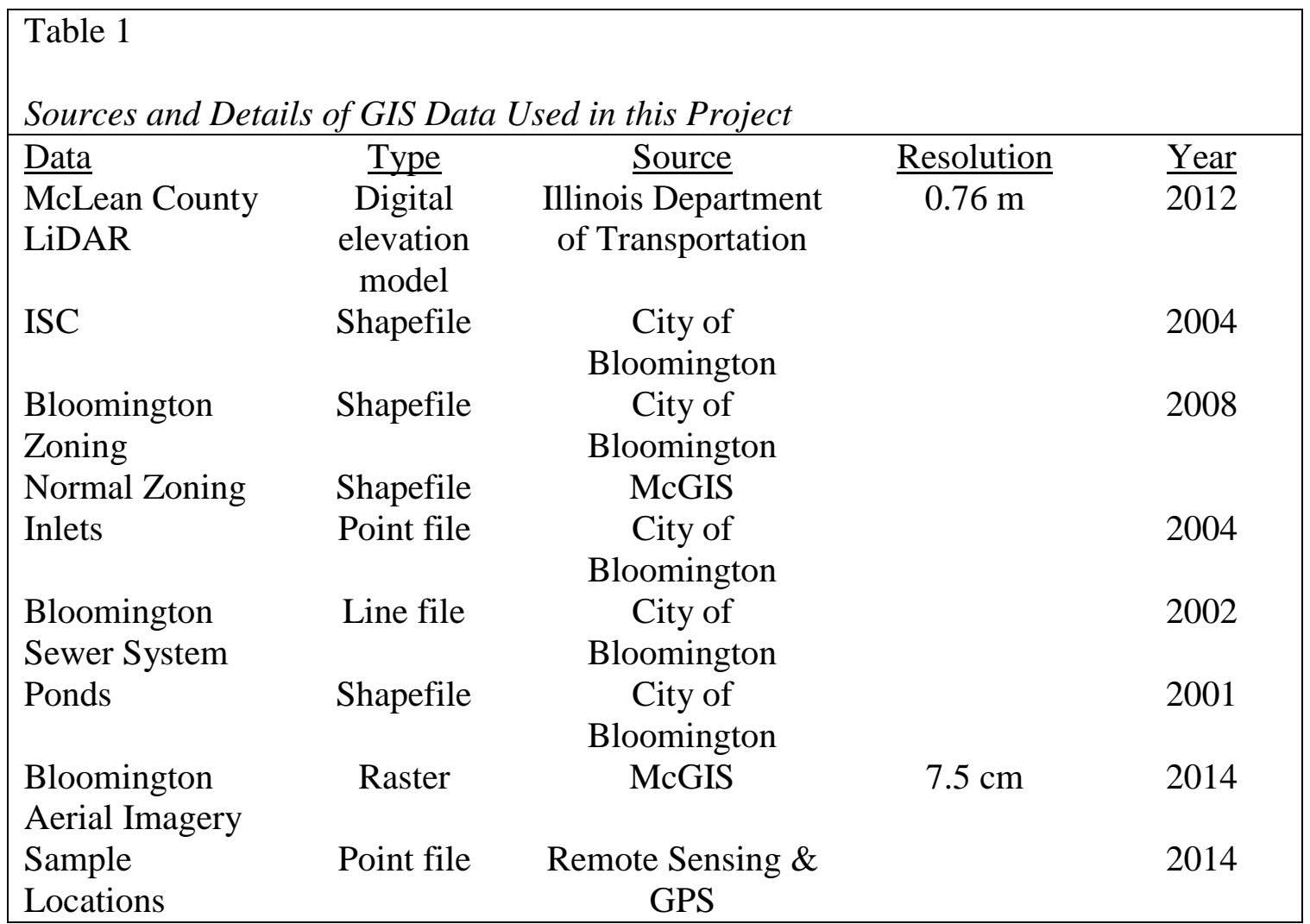

Bloomington and the surrounding areas, divided up into 0.76 meter squares, which makes the file size very large. In an effort to reduce the amount of time to process data, we restricted the processing extent to the area surrounding the storm sewer network. The reduced geographic extent for each storm sewershed improved GIS processing time of each attempt from several hours to under a minute in most cases. In cases where we underestimated the contributing area we expanded the processing extent and ran the processes again. We generated a model of the entire process so that it was easily repeatable; we simply changed the input files in order to run it for each storm sewer system.

We used the $\mathrm{d} 8$ method (Tribe, 1992) to delineate our storm sewersheds. It used topography and the location of a pour point. The key difference between our 
methodology and the standard watershed methodology was the location of the pour points. Instead of being located at the mouth or junction of stream, our pour points were located at the inlets to storm sewers. Storm sewer systems in this study included as few as 2 inlets and as many as 463 . The first step in the $\mathrm{d} 8$ method was to remove any sinks (typically erroneous cells that are completely surrounded by higher cells), and fill those sinks to smooth the topography. Then we determined flow direction for each cell. This process assumes that a cell will contribute water to one of its 8 surrounding cells, specifically the one with the greatest slope downhill. The watershed function was then used to determine which uphill cells contributed water to a selected point called the pour point. The watershed function delineated a contributing area for each inlet, we reclassified the area to be represented as a whole for classification of the physical characteristics.

There is inherent horizontal error in both the DEM and the pour point layer, meaning that the location of the pour point in its layer may not line up with its location on the DEM. To ensure the optimal pour point is chosen another file was created called the flow accumulation. This file is a representation of the number of cells that contribute to each cell. The pour points were then snapped to the highest point of water accumulation (i.e. the cell that has the most cells contributing water to it) within a specified map distance (Figure 2). Snapping the pour points varied among the different storm sewer systems. The original distance threshold allowed for a pour point to snap was $1.5 \mathrm{~m}$, allowing for the same amount of horizontal error that is documented for the inlet layers. Even still, delineating watersheds became an iterative process as some inlet locations produced areas of only a few pixels. Such inaccurate delineations were likely due to the 
combination of inherent error between the DEM and inlet layers. We extended the snap radius by intervals of $0.76 \mathrm{~m}$ until all inlets produced a reasonable area. The furthest snap radius used was $4.5 \mathrm{~m}$ (Table 2). Some inlets were compared to the flow accumulation layer and determined they would not create an area.

Once the area of each storm sewershed was delineated, we used a variety of spatial analysis methods to determine the physical characteristics of each sewershed. Originally the watershed function determines the area that contributed to each inlet. The total watershed area was merged through a reclassification so that the total sewershed for each sample point had a value of 1 (Figure 2). Since the impervious surface layer was published in 2004 and construction had taken place, we used the aerial imagery to digitize the new roads and structures manually. The impervious surface layer for the entire city was then converted to a raster and reclassified so that the impervious

\begin{tabular}{|lc|}
\hline Table 2 \\
\begin{tabular}{|l} 
Various Snap Distances \\
Snap Distance (m)
\end{tabular} & $\frac{\text { Number of Storm Sewersheds }}{4}$ \\
2.5 & 5 \\
3 & 4 \\
3.8 & 3 \\
4.5 & 2 \\
\hline
\end{tabular}

area was also given a value of 1 and the pervious area was given a value of 0 . We multiplied the impervious surface layer and the total sewershed area in raster calculator 
and where the two coincide in the resulting layer yielded a value of 1 sewershed. We then computed the percentage of ISC by dividing the number of cells that were considered impervious by the total number of cells in the storm sewershed. This was then converted to back to a polygon file, and, the resulting shapefile was converted back to raster in order to get the area.

The zoning layer was clipped to the area of the storm sewershed first and then converted to raster. The zoning layer was classified by zoning type, and then the area of each was calculated by multiplying the number of cells by the area of each cell $\left(0.6 \mathrm{~m}^{2}\right)$. We aggregated different zoning classifications into 4 groups (Table 3): commercial, residential, open space and roads. Roads were not an official zoning classification; rather, roads were the only area of the city that was unzoned. They are considered important in this study because stormwater was directed to roadways to be efficiently transported to the storm sewer. Therefore, the zoning percentage of each storm sewershed was compared to its total area and any cells not assigned a zoning classification were assumed to be a roadway and a percentage of road was calculated as the remaining percentage. Inlet density was calculated by simply dividing the number of inlets in the storm sewer system by the area of the storm sewershed. 


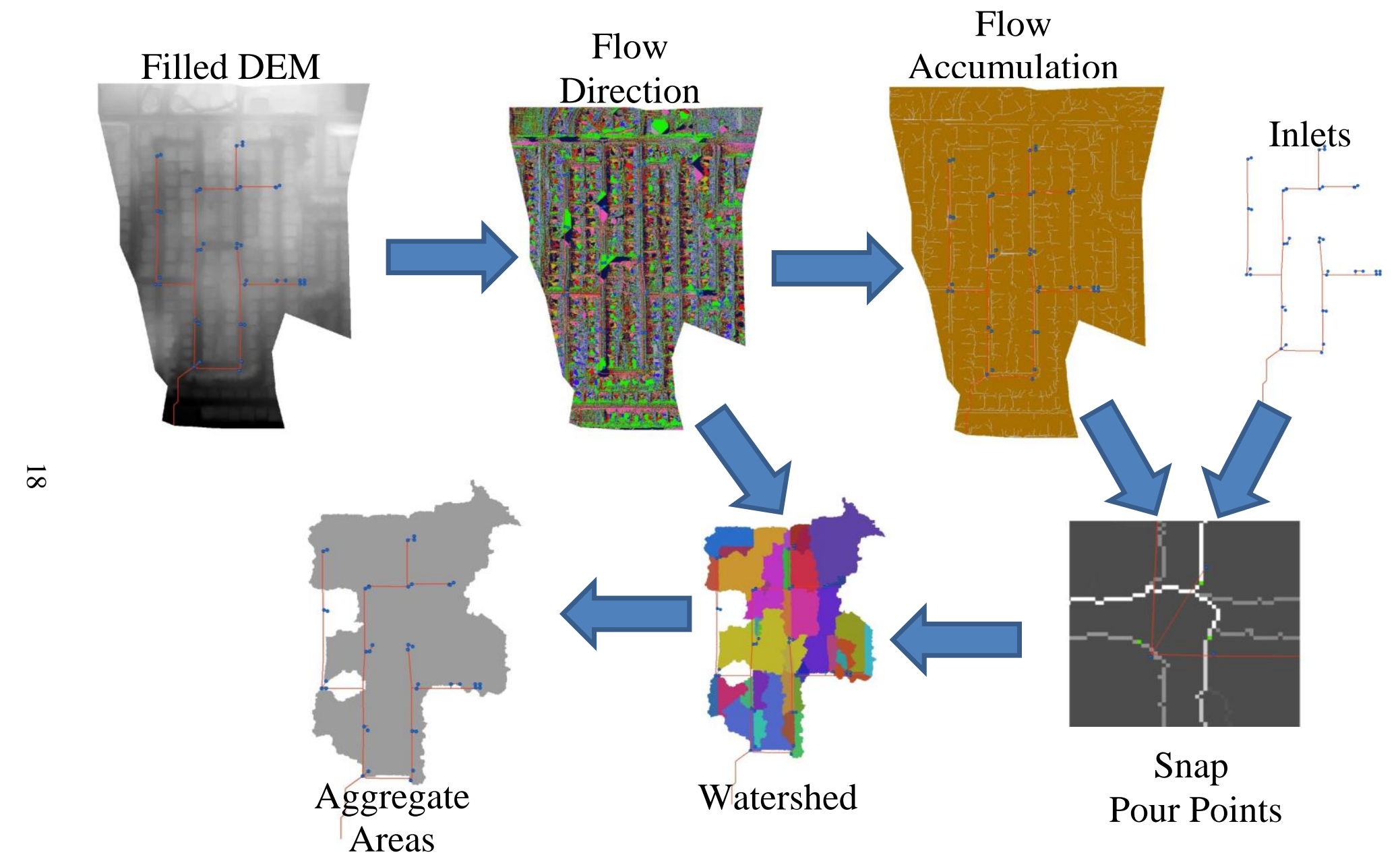

Figure 2. GIS Workflow. The GIS processes used to delineate storm sewersheds starting with a filled DEM and inlet data layers. 


\begin{tabular}{|lc|}
\hline Table 3 & \\
Zoning Classification Groupings & \\
\hline Zoning Classification & Grouping \\
M-1, C-1, C-2, C-3, B-1, B-2 & Commercial \\
R-1A, R-1B, R-1C, R-2, R-3A, R-3B & Residential \\
A, S-5, S-2 & Open Space \\
Unzoned & Road \\
\hline
\end{tabular}

We considered some features in storm sewer systems based simply on presence or absence. These features did not require the delineation of the storm sewershed; rather they are part the storm sewer system. The most obvious of such features are ponds. There are two types of ponds that may be included in storm sewer system: detention ponds and retention ponds. Detention ponds are designed to be dry between storm events; some are used parks or playing fields. Retention ponds always have water present; they may also have aerators or circulators. Although both pond types will have plant life, they may be clay lined and do not offer an opportunity for infiltration. The City of Bloomington supplied a data layer of the detention and retention ponds (hereafter referred to as ponds), and which allowed us to note those storm sewer systems with a pond present and those that did not. The other common features in our study area are sump pumps. Due to the poor drainage of glacial soils, sump pumps are installed near buildings to draw water away from the foundation to prevent damage. These pumps feed directly into the storm sewer system. The presence or absence of sump pumps was determined from the sewer system layer where they were classified as "tile drainage" (pers. comm., Kevin Kothe). 
Statistical analyses were performed in JMP 10.0 software (SAS, 2012). We compared the physical characteristics to determine patterns using linear regression and Tukey-Kramer means test. Data were log transformed to normalize data as necessary to meet assumptions of homogeneity of variance.

\section{Results and Discussion}

Delineation of storm sewersheds yields some interesting results, especially when comparing it to the more common task of delineating natural watersheds. Storm sewersheds, of course, differ from natural watersheds in that the latter is delineated in GIS software typically using only one pour point. Storm sewersheds here were generated from multiple pour points, which are connected via an underground pipe network leading to an outlet into a stream. Unlike natural water catchments, storm sewersheds were not always continuous (Figure 3), in that the areas contributing to adjacent pour points may not be adjacent to one another. This was because storm sewersheds occur within natural watersheds and are constructed according to the designs of civil engineers and city officials. Some areas within an urban setting drained directly into the stream rather than through a storm sewer system. In some cases there were instances of this occurring within a storm sewershed between inlets. This also may be a result of the pipe crossing a topographical border (Crimmens, 2006). Figure 3 shows as storm sewershed with three inlets. The two inlets to the north have contributing areas adjoining borders. The third inlet had a separate area that does not join with the others. It is assumed based on the flow accumulation layer that the area between the inlets either flowed contributes to a different storm sewer system. 


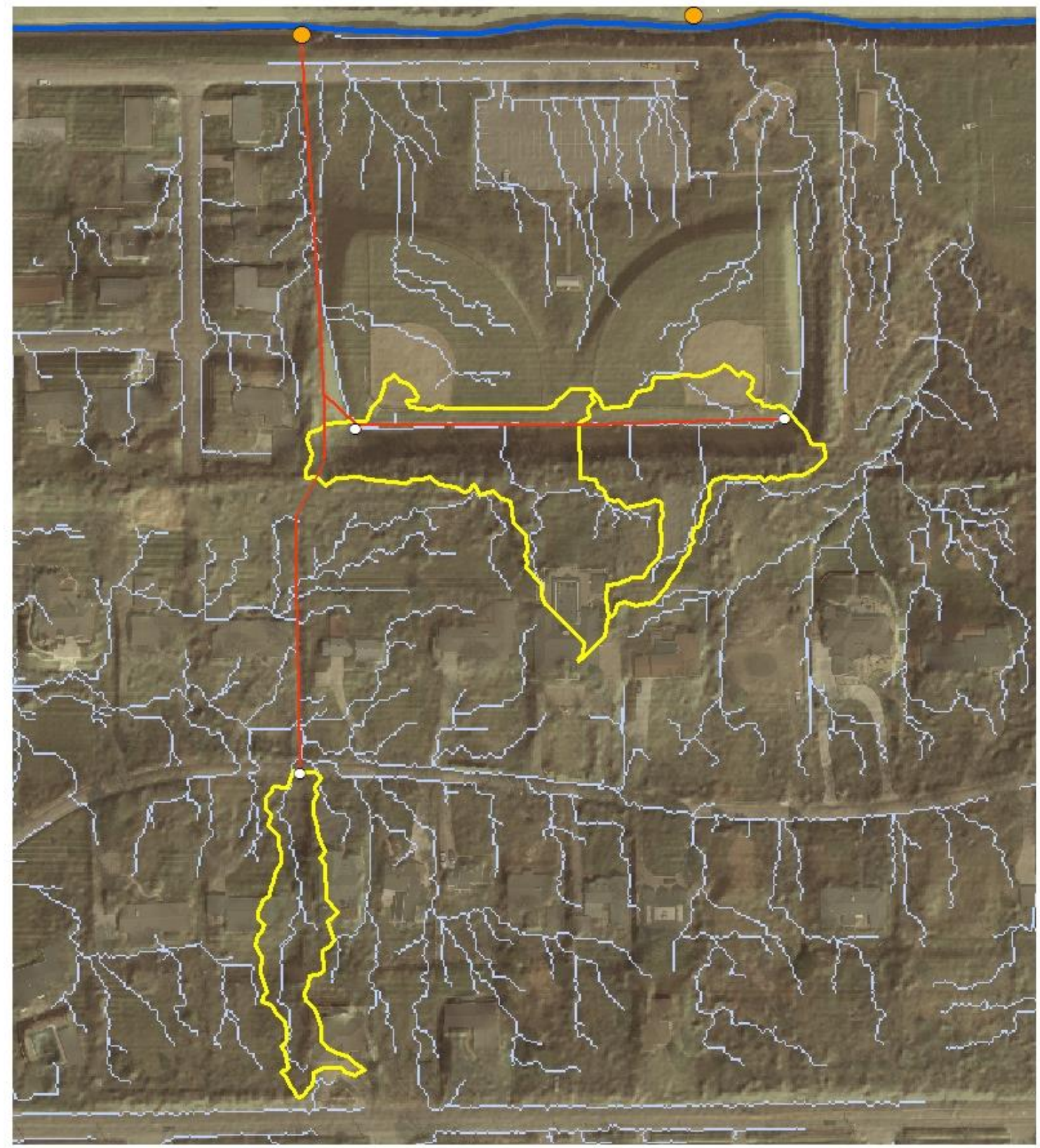

Legend

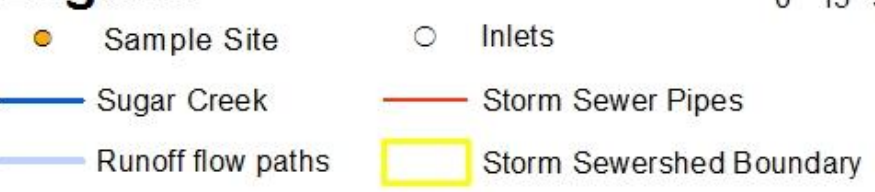

Meters

120

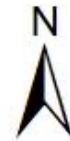

Figure 3. Storm Sewersheds may be Non-Continuous. This storm sewershed demonstrates how it is different than natural watersheds. It is non-continuous (creates more than one polygon) and has multiple pour points. Notice too how the two pour points in the north share a boundary and how the flow lines between the north and south inlets flows to the west. 
The shape of the storm sewershed was primarily dictated by two features: the location of the storm sewer inlets and the roads. Storm sewer system networks that were long and skinny had storm sewersheds that were long and skinny (Figure 4). Square-

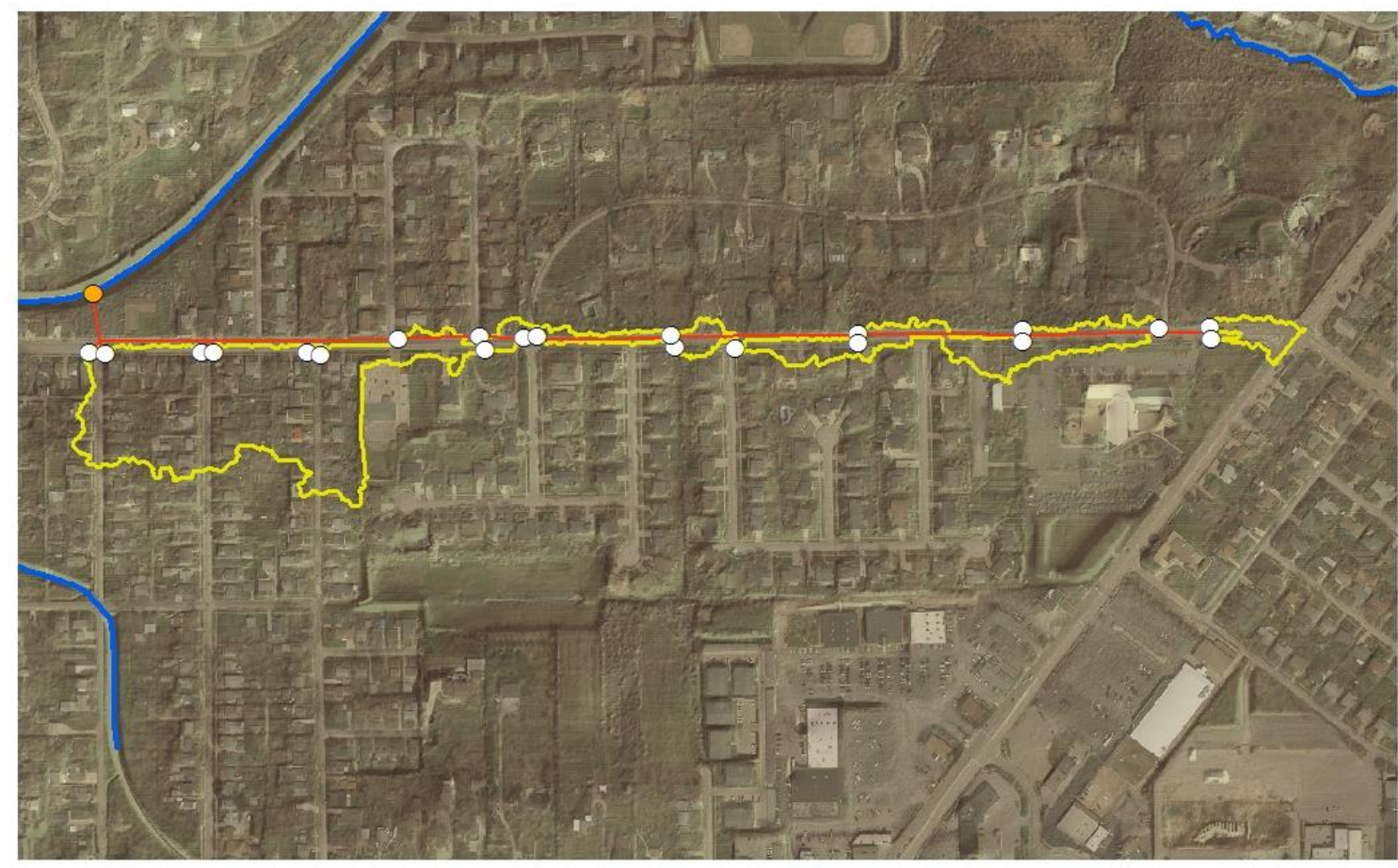

\section{Legend}
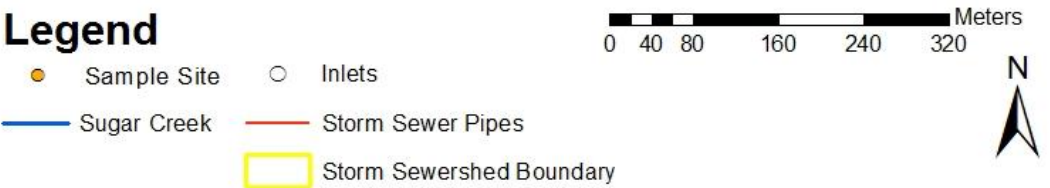

Figure 4. A Long and Skinny Storm Sewershed. This storm sewer system follows a single road, the storm sewershed reflects this shape.

shaped storm sewer system networks had storm sewersheds more square like (Figure 5). Maps, descriptions and photos for all eighteen storm sewersheds are in Appendix A.

Roads are raised in the center (also called the crown) so that storm water will be directed to the curb where it will flow to the storm sewer inlets. This is intended to create a boundary for stormwater so that it is directed to the sides of the road, but the difference in 


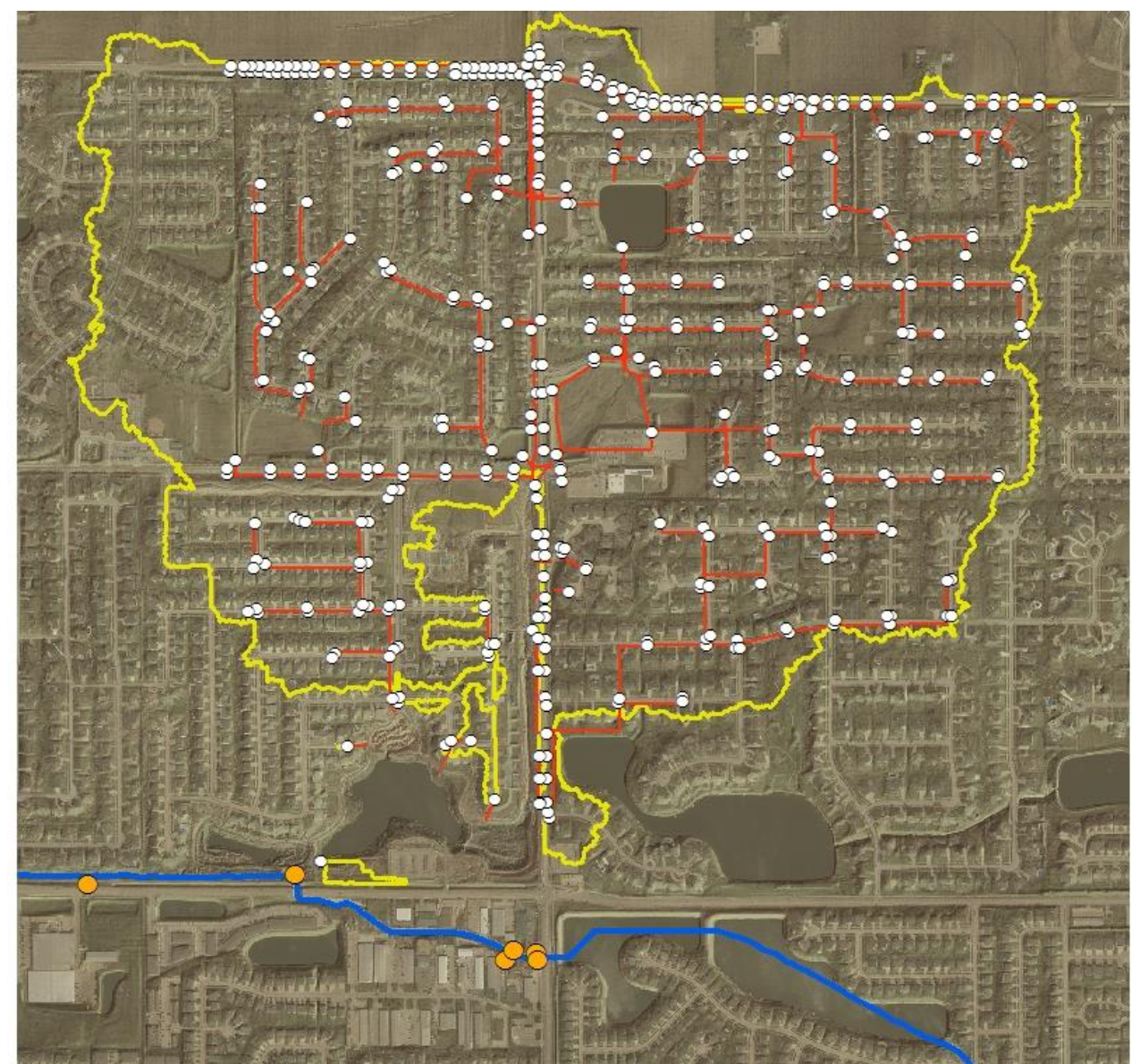

\section{Legend}

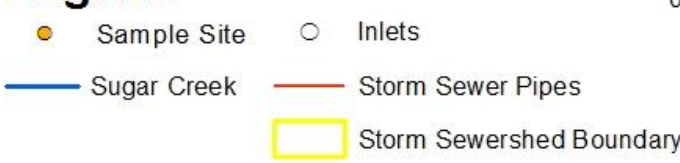

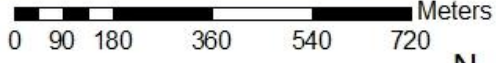

$N$

Figure 5. A Square Storm Sewershed. This storm sewer system has many branches. The contributing area generally creates a square-like polygon around it.

elevation was a matter of centimeters, much smaller than the vertical accuracy of the LiDAR which was 0.4 meters. This may be why Figure 6 extended beyond a road to the south making the storm sewershed much larger in area than we expected. At the same time, this may not entirely be due to data error, but rather due to the presence of flood routes. Flow paths such as these are often created intentionally by city engineers to keep water flowing during a large event when inlets may be overburdened. Flood routes allow 
water to continue moving past such inlets until they reach an available inlet. However, during the average rainfall event it is unlikely that the entire area actually contributes to the storm sewer system in Figure 6. This problem could potentially be fixed by introducing breaklines to prevent flow from extending past a road. Such a fix would lead to a loss of insight into possible flood routes by restricting the flow of water. In fact, we verified with the City of Bloomington that there is a flood route present in this location (pers. comm., Kevin Kothe). It is also worth mentioning that the western boarder of the storm sewershed in Figure 6 does follow the center of a road. However in this case the road in question is large and includes a raised median in the center. This difference creates not only a larger different in the elevation between the center of the road and the curb but also a more abrupt boundary. The larger change in elevation makes the difference closer to the horizontal accuracy of the DEM and the abrupt boundary is significant because the direction of flow is determined by the direction of the steepest slope. 


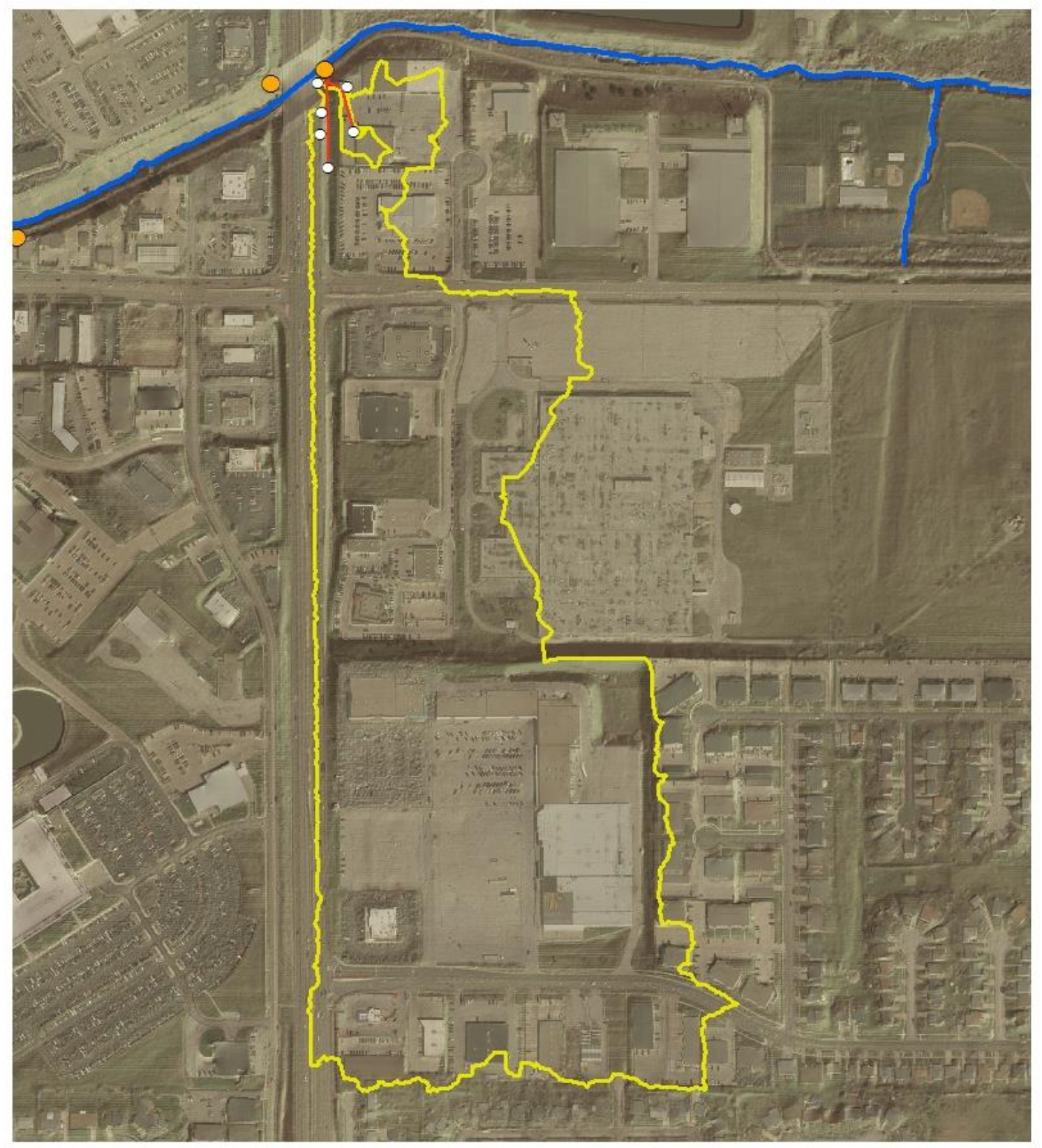

\section{Legend}
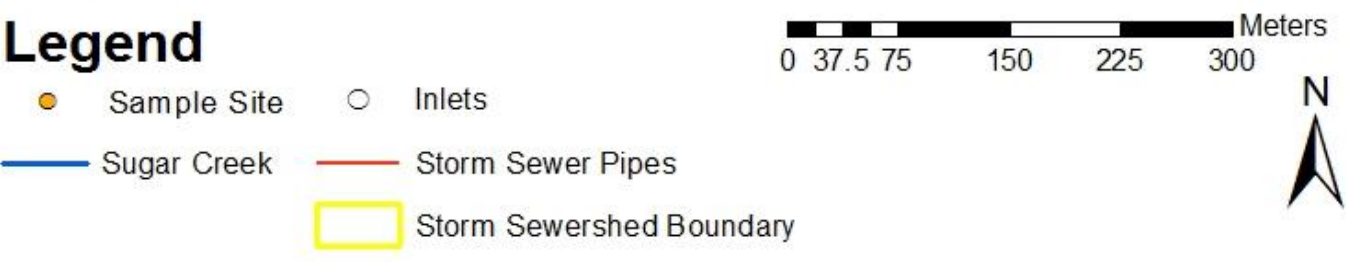

Figure 6. A Storm Sewershed with a Flood Route. This storm sewershed was expected to end along the first east-west road, but it far exceeds it. Its western border also follows the center of a road. 
While the area of the storm sewersheds tends to follow the general shape of the storm sewer system we note a few exceptions. The first is illustrated in Figure 7, this storm sewer system presumably drains a parking lot but did not delineate as such. This may be because of discrepancies in the combined horizontal error between the inlet locations (whether from data provided by the city or generated through the aerial photograph) and the LiDAR data. It should be noted that the storm sewer system in Figure 7 was not in the original dataset provided by the City of Bloomington. However, the City of Bloomington was able to provide plans of the property and the storm sewer line was delineated manually based on those plans and aerial imagery. The manual delineation may have caused a greater horizontal error than the other storm sewersheds.

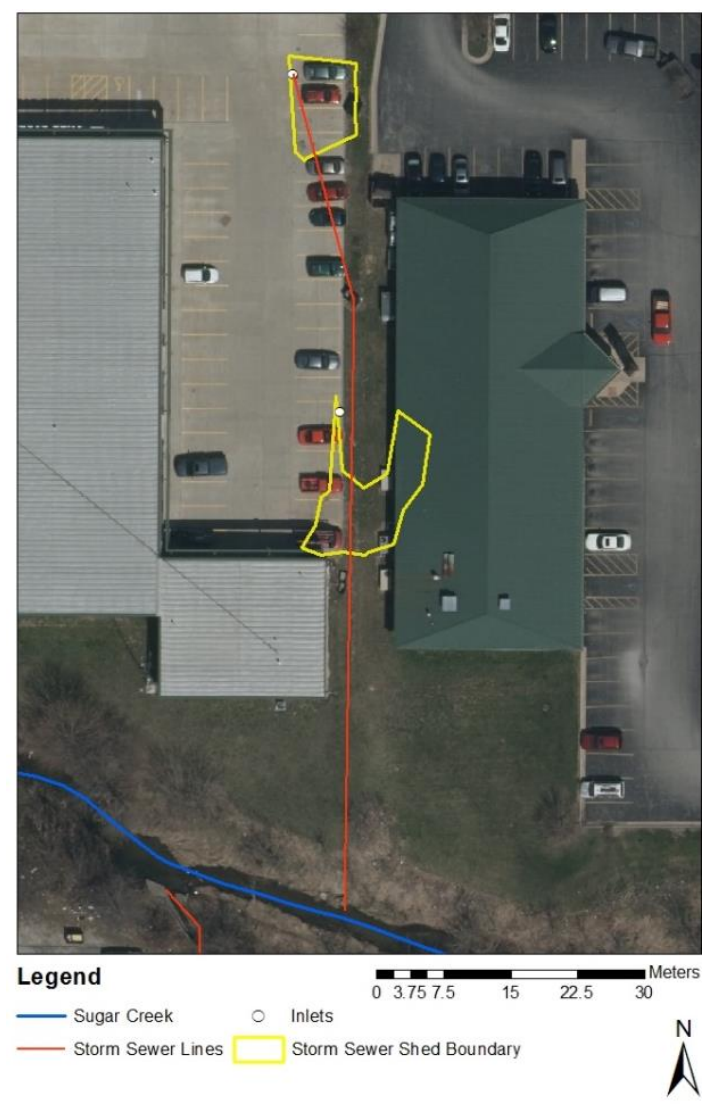

Figure 7. A Storm Sewershed with an Underestimated Area. We expected this storm sewershed (generated by our GIS model) to include the entire parking lot to the west. 
A combination of the flow accumulation layer and aerial imagery gave insight to accuracies and errors of this project. Flow accumulation is a data layer that denotes where channels are likely to form based on how many cells contributed water to a single cell. As previously mentioned, storm water was intended to flow along the curb of the road, therefore we should have seen flow accumulation lines align with the curb of the road. Figure 8 shows an example of how this was portrayed as we would expect by our model; indicating that an unaltered LiDAR derived DEM was capable of producing a qualitatively accurate flow model in an urban environment. An example of an error in our model was the flow travelling through a building (Figure 9). This was a limitation of our model as in actuality the storm water would flow around the building. The model allows this type of error because, as mentioned in the introduction, the structures are removed from LiDAR to provide a "bare-earth" model of terrain. The other inaccuracy in Figure 9 is that the flow crosses the road. As previously mentioned the road should act as a boundary. Instead of crossing the road we would have expected the flow path to continue east along the curb up the road until it reached the inlets. In this case the difference in the flow path was outside of our maximum snap pour point distance and these flow paths were excluded from storm sewershed.

There are two possibilities to fix this error. The first would be to use the unfiltered LiDAR although this data set would include a great deal of noise due to the presence of vegetation and would certainly lead to other errors. The other possibility to correct the inaccuracy of the flow path could be fixed with the use of burning. This method would alter the DEM to raise buildings and lower roads (Elgy et al. 1993). In theory flow would then be forced away from buildings and towards roads. This would be a time consuming 
process as it requires a data layer of just the buildings and another with just roads. If we consider the delineation of the flood routes not to be a limitation, but an indication of the available routes then only one storm sewershed was delineated in serious error and it was generated manually. 

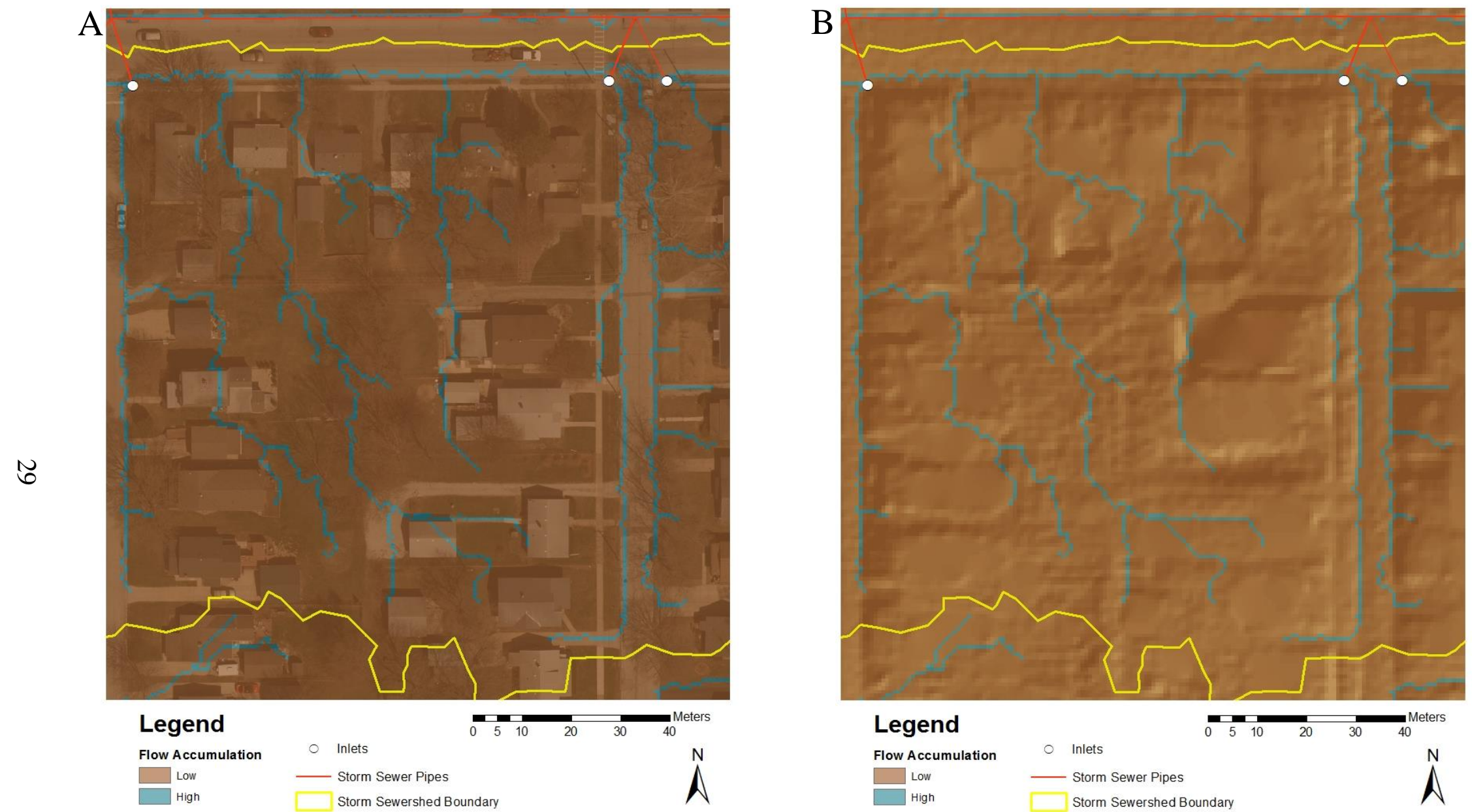

Figure 8. Flow Accumulation Lines Along Road Curbs. An example of how our model represented what is expected based on engieering design. The aerial imagery on the left (A) shows how the flow accumulation is near the curb on the road. The right image (B) is the same area shown in hillshade to express topography 


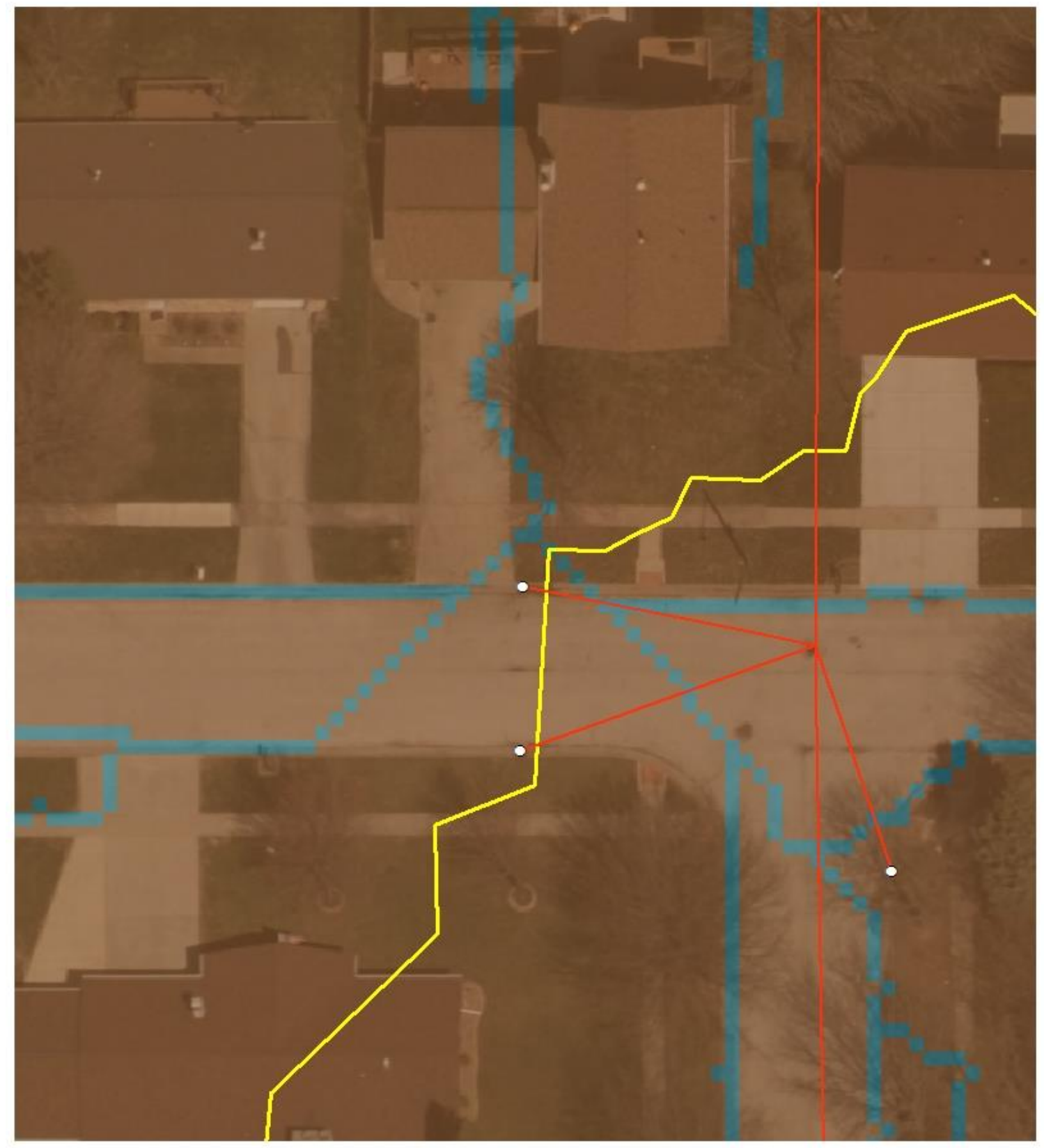

Legend

Flow Accumulation

Low

High

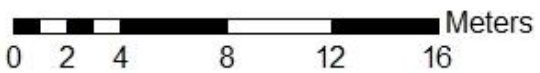

Inlets

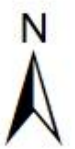

Figure 9. Flow Accumulation Lines Through a Building. The flow line runs north through a building, an error in our model. Additionally, the flow crosses the road and avoids the two pours points and limiting the boundary of our storm sewershed. 
The characteristics of the storm sewersheds showed great variation. The \%ISC varied from $10-70 \%$ among the storm sewersheds. The median \%ISC was $30.7 \%$. Of the four zoning classifications we considered, three were the primary classification for at least one storm sewershed: eleven storm sewersheds were dominated by residential zoning, six storm sewersheds had commercial as their primary zoning, and one storm sewershed was dominated by open land. None of the storm sewersheds were dominated by nonresidential or noncommercial roads. Storm sewersheds that had a higher percentage of commercial zoning correlated with those that also had a greater \%ISC $(\mathrm{p}<0.01)$.

The density of inlets ranged from 25 inlets per $\mathrm{km}^{2}$ to 10,000 inlets per $\mathrm{km}^{2}$. Although note that the lowest inlet density is likely due to the inclusion of a flood route (Figure 6) and the storm sewershed and the largest inlet density is due to do manual creation of the storm sewer system (Figure 7). Nine of the storm sewersheds had an inlet density between 100-200 inlets per $\mathrm{km}^{2}$, four had 200-300 inlets per $\mathrm{km}^{2}$ and two had 400-600 inlets per $\mathrm{km}^{2}$.

Our analysis showed there are some apparent relationships between physical characteristics. We found that the number of inlets, the length of storm sewer pipe, and amount of impervious surface area were all correlated with the overall area of the storm sewershed $\left(\mathrm{p}<0.0001, \mathrm{r}^{2}=0.912, \mathrm{p}<0.0001, \mathrm{r}^{2}=0.854, \mathrm{p}<0.0001, \mathrm{r}^{2}=0.943\right.$ respectively $)$ (Figure 10). 


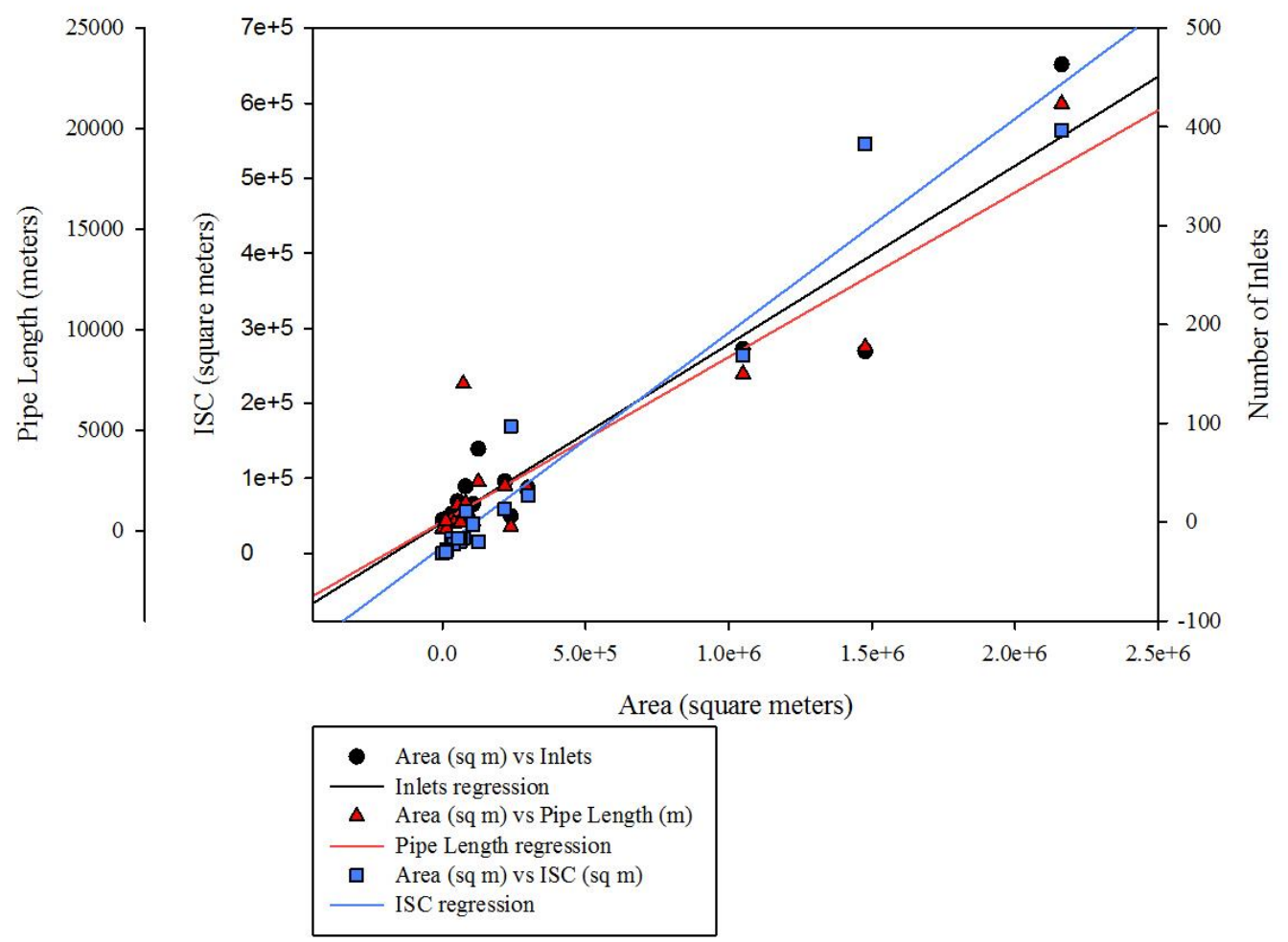

Figure 10. Correlations of Physical Characteristics. Chart with correlations of area to inlet count, pipe length and ISC area. $\left(\mathrm{p}<0.0001, \mathrm{r}^{2}=0.912, \mathrm{p}<0.0001, \mathrm{r}^{2}=0.854\right.$, $\mathrm{p}<0.0001, \mathrm{r}^{2}=0.943$ respectively)

Determining the presence or absence of ponds and sump pumps did not require spatial analysis, because they were a feature within of the storm sewer system. Six storm sewersheds had ponds present, 12 storm sewersheds did not have a pond. Ponds were present in significantly larger storm sewersheds $(\mathrm{p}<0.0001)$. There are 9 storm sewersheds with sump pumps and 9 without sump pumps. They were identified as a category within the sewer layer. Sump pumps were present in storm sewersheds with significantly greater area than storm sewersheds without sump pumps $(\mathrm{p}<0.0001)$. In addition all 6 of the storm sewersheds with ponds also had sump pumps. Sump pumps are primarily located in the newer (eastern) portion on the city. On occasion sump pumps that 
are connected to the storm sewer system are not within the boundaries of the storm sewershed (Figure 11). We recognize this but do not consider it a limitation of the study. Sump pumps draw shallow groundwater to keep building foundations dry so they do not act in the same manner as an inlet. However, that water would have infiltrated from the surface. The details of each storm sewershed's characteristics are in Appendix B.

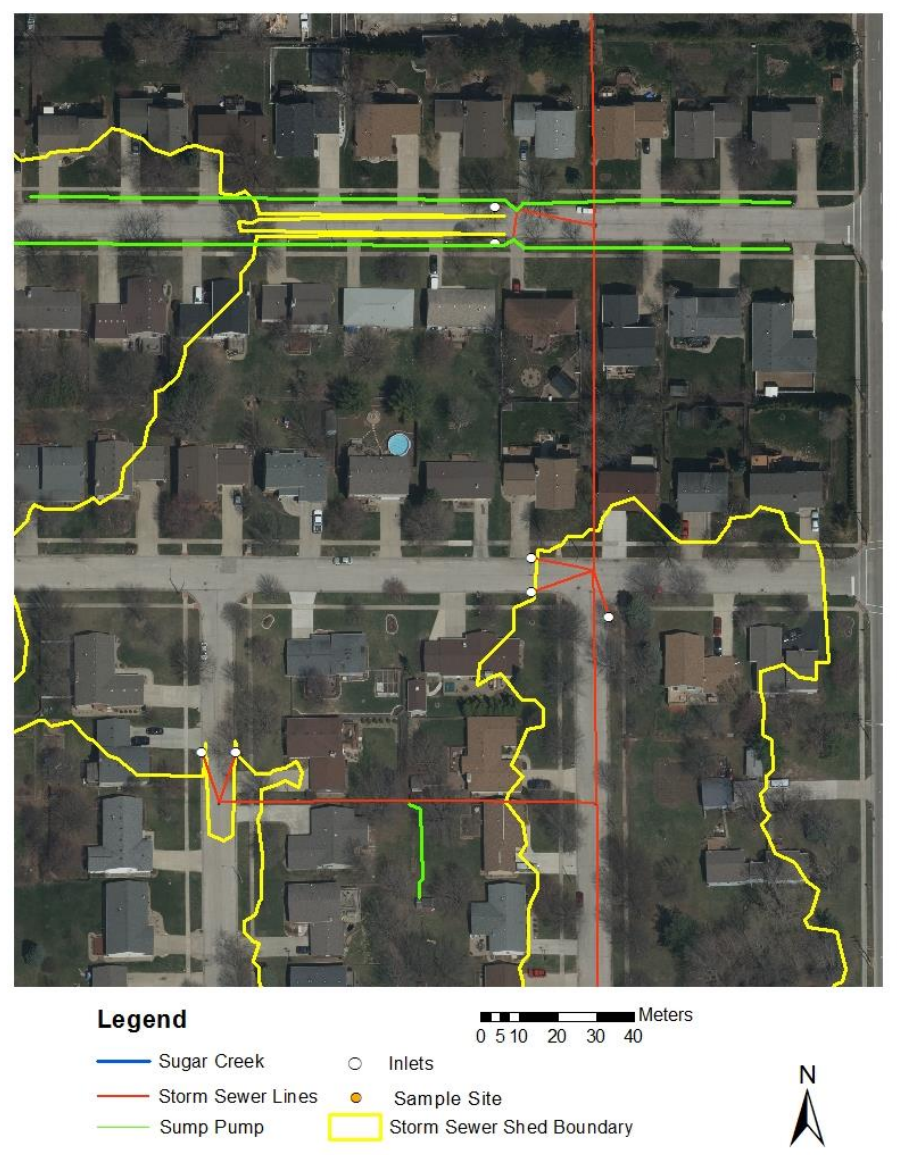

Figure 11. Sump Pumps may be Outside Storm Sewershed Boundaries. An example of how sump pump connection (green) may be located outside of the storm sewershed area (yellow)

\section{Conclusions and Future Work}

The main goal of this part of the study was to delineate storm sewersheds using GIS with readily available data. In many ways our model yielded results we expected 
based on engineering principals but there were some factors that remain limited. The small cell size of LiDAR helped detect some the subtle topographical changes in an urban area in central Illinois. The limiting factor however is the vertical resolution of the DEM. It is possible that when the storm sewershed boundaries exceeded a road it was because the LiDAR did not detect the crown of the road. Another possibility is a flood route is being detected and only a portion of the storm sewershed would contribute water depending on the magnitude of the storm. There was only once instance in our study in which a storm sewershed was obviously grossly underestimated and it was likely due to human error in manual delineation.

We acknowledge there are some limitations of this study but we would also argue that our methodology provides insight into urban stormwater drainage areas. Future work could involve field verification of a specific storm sewershed or sampling of significant locations. For example, locations in which inlets do not produce a contributing area or where a flow path flows through a house. Field verifications could give insight into how often the methodology is accurate.

Storm sewershed were found to have variation in their characteristics. Some characteristics are related to another characteristic, others are indicative of the use within the storm sewershed. These variations may become important as we continue to analyze their effects on water quality.

Future studies could manipulate the DEM to force flow away from buildings and towards roads in an effort to reduce error. Other manipulation that could be used would be introducing breaklines at known boundaries such as roads. However, it is important to 
consider the time and effort that may be put into creating the necessary layers and if the manipulations will bias the results.

\section{Possible Applications}

There are several possibilities to use this methodology in practice. The first would be a simple verification of drainage patterns in an urban area. Essentially, the model could be used to confirm if the drainage paths and areas the engineers design continue to hold. As time passes, flow paths may be disturbed or altered within the addition of new infrastructure. This methodology could allow verification of drainage old drainage paths with minimal field work.

This methodology could be used to model drainage patterns for storm sewer systems that haven't been installed yet. Analyst could create several different layouts of storm sewer pipes, inlets to optimize drainage. It could also be used as cost analysis tool, to determine what layout will drain the intended area for the least amount of money. In addition, the methodology could be used to determine optimal placement of a feature such as a detention pond in a proposed or existing system. As storm sewer systems are updated and retrofitted the drainage patterns will be affected, and this methodology could be used to determine what those changes might be.

One of the key differences between storm sewersheds and watershed is the underground component that allows stormwater to cross topographic lines. This methodology could be used to determine where instances of this take place and preventing the occurrence of topographic cross. 


\section{CHAPTER III \\ EFFECTS OF PHYSICAL CHARACTERISTICS OF URBAN STORM \\ SEWERSHEDS ON THE WATER QUALITY}

\section{Introduction}

There are predictable hydraulic responses to urban development (Walsh et al., 2005a). Due to the increase in the percentage of impervious surface cover (\%ISC), runoff occurs eight times more often in urban areas than forested areas (Gallo et al., 2013). Storm sewer systems efficiently transport runoff to the stream in an effort to prevent flooding and damage. Storm water travels over the land surface and eventually drains to a storm drain which discharges to a stream (Figure 12).

Changes in the urban landscape alter the hydraulic response. Decreased retention of storm water increases the peak discharge level (Bloschl \& Sivapalan, 1995; Cantone \& Schmidt, 2011). As a result, the majority of contaminants enter streams and rivers as a result of stormwater runoff (Walsh et al., 2005b; EPA, 1999). Watersheds with storm drains have high concentrations of nutrients (Kaushal and Belt, 2012). And it has been consistently shown that urban settings will have more degraded water resources than forested streams (Walsh et al, 2005a, Cunningham et al., 2009, Kaushal and Belt, 2012).

Features of storm sewer systems affect water quality. Detention ponds, whether intentionally designed to or not, will provide some water quality control (Marsalek, 2002; Herrmann, 2012). Originally designed to reduce the peak flows during a storm, ponds 


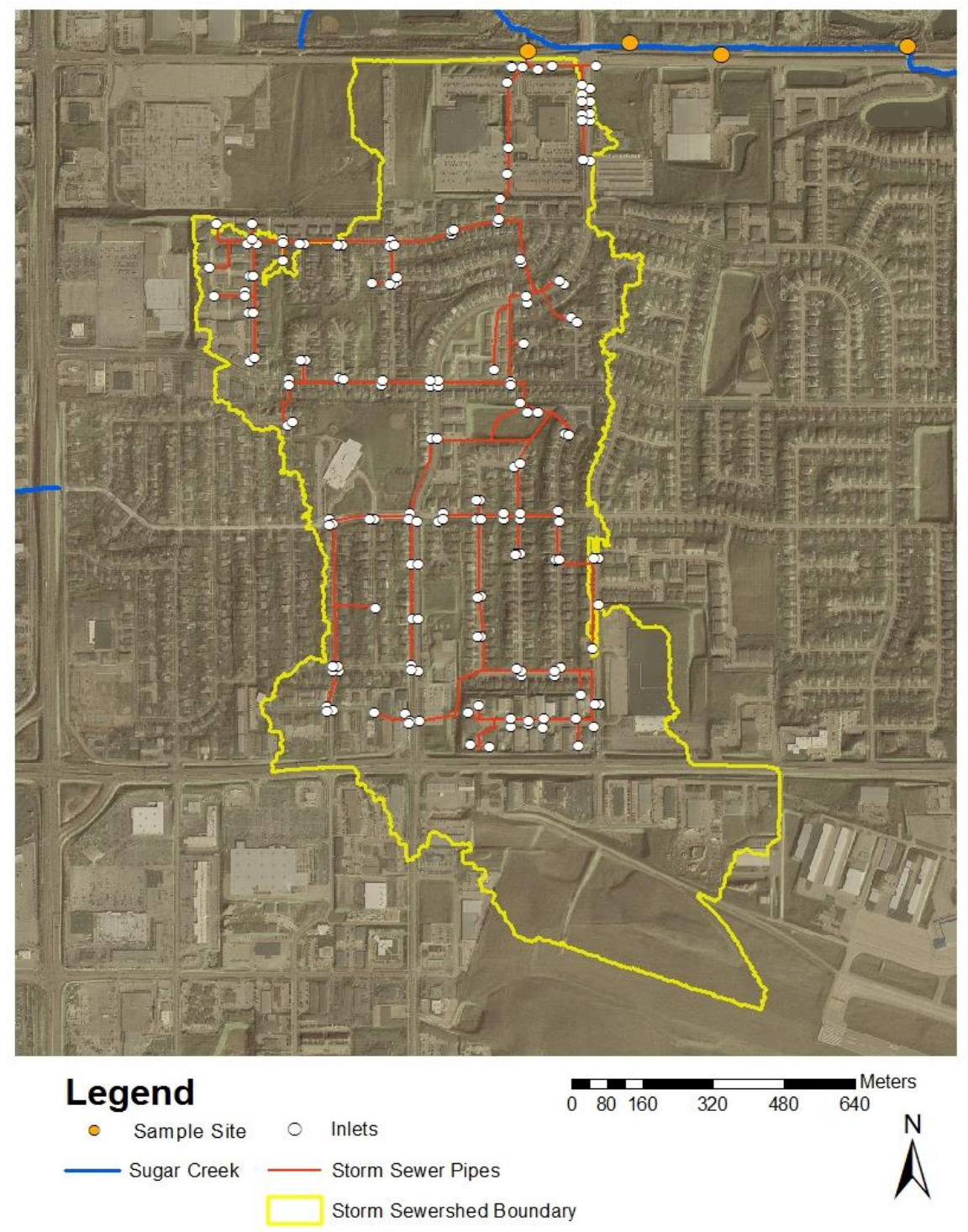

Figure 12. An Example of a Storm Sewer System. The red lines are the storm water pipes the white dots are the inlets. The yellow line outlines the storm sewershed. The blue line is the stream the water it discharges to and the orange dot indicates our sampling site

will provide treatment through the settling of sediment (Tixier et al, 2001; Marsalek, 2002). Ponds can reduce nutrients in stormwater by $43 \%$ for nitrogen and $35 \%$ for phosphorous (Herrmann, 2012). Concrete ditches and pipes that transport stormwater to river also can alter chemistry. In one study it was found that rain water collected from a 
roof had a $\mathrm{pH}$ of 4.8 that increased to 7.9 after 100 minutes of being in contact with concrete (Davies et al, 2010). In short, stormwater quality is dependent on the land surface it travels over (Gallo et al, 2013; Choe et al, 2002; Chow and Yusop, 2014). Questions remain, however, about how the differences in physical characteristics among urban storm sewersheds affect water quality.

In this part of the study we address the question: what physical characteristics of urban storm sewersheds affect storm water quality? The characteristics we predicted would have the greatest impact on water quality were: presence of a retention pond, inlet density, and \%ISC. Other characteristics we considered were storm sewershed area, presence of sump pumps and zoning. We monitored the water quality of storm water at the outlets of eighteen different storm sewer systems in Bloomington, IL during seven storm events between May 2014 and February 2015. We expected that the presence of a retention or detention pond in a stormwater sewershed and high storm inlet density would improve water quality. We predicted that as sewer miles and \%ISC increase, water quality would be more degraded.

\section{Study Region and Study Period Overview}

This study was conducted in Bloomington, Illinois. The City of Bloomington is located approximately 125 miles southwest of Chicago. Immediately north of Bloomington is the Town of Normal. The two municipalities are so close they are locally known as the "Twin Cities." The combined area of the cities is over 90 square kilometers. The combined population of the two cities is approximately 125,000 (US Census, 2010).

A stream, Sugar Creek, flows along the border of Bloomington and Normal (Figure 1). All of the sites in this study drain into Sugar Creek. The storm sewer systems 
included in this study were primarily owned and maintained by the City of Bloomington. Three systems also had connections with private owners and one system was entirely private. It should also be noted here that some storm sewer lines, whether public or private, may not appear on maps as underground features can be easily overlooked or forgotten.

Geologically, the city of Bloomington is located on an end moraine of the Wisconsin Glaciation. The geology of the area is primarily glacial till of the Wedron Formation composed of pebbly clay till (Weibel and Nelson, 2009). There is also a thin alluvial deposit (Stiff, 2000) along Sugar Creek.

The majority of the storm sewer system in Bloomington was built between 1950 and 1980, making the system, at least in part, slightly older than the national average of 45 years (Chang \& Hernandez, 2008). Much of this system requires replacement and expansion. The Municipal Separate Storm Sewer System (MS4) regulates the city of Bloomington with a permit administered by the Illinois Environmental Protection Agency. The city of Bloomington has committed to make efforts over twenty years to improve stormwater quality (City of Bloomington, 2013). The pipes were made of PCC, clay brick or polyvinyl chloride (PVC) (pers. comm., Kevin Kothe) and vary in size at their outlets from $30 \mathrm{~cm}$ to $364 \mathrm{~cm}$. The storm sewer system studied is primarily gravity fed; except for sump pumps.

Between the months of May 2014 and February 2015 eighteen storm sewer systems were sampled for water quality during flow events. This study is limited in that only one sample was collected from the outflow of each storm sewershed during each event. We aimed to take a sample near the beginning of each storm event, but it was not 
possible to know exactly at what point in the hydrograph a sample was taken. However, we assumed that relationships across the storm sewersheds would remain constant no matter what point on the hydrograph sample collection took place.

\section{Methods}

Storm Sewershed Characterization

We measured stormwater quality from eighteen storm sewersheds within the city of Bloomington (Figure 1). For each storm sewershed we considered the following characteristics area, storm sewer density, sewer miles, number of inlets, inlet density and $\%$ ISC, primary zoning classification, presence or absence of a retention or detention pond and presence or absence of sump pumps (Table 4).

The storm sewersheds were delineated in ArcCatalog 10.2 using Model Builder. Storm drain inlets were used as pour points and contributing area was determined by topography. We used a $0.76 \mathrm{~m} \mathrm{LiDAR}$ dataset flown in 2012 as the elevation layer (ILDOT, 2012). Storm sewer miles were calculated for each storm sewershed from the storm sewer system layer provided by the City of Bloomington (City of Bloomington, 2002). Area, storm sewer density, and percent impervious surface cover and primary zoning classification were derived in ArcMap 10.2 from the storm sewershed results in combination with data layers provided by the City of Bloomington (See Chapter 2). 


\begin{tabular}{|c|c|}
\hline \multicolumn{2}{|c|}{$\begin{array}{l}\text { Table } 4 \\
\text { A Summary of Physical Characteristics of the } \\
\text { Storm Sewersheds in this Study }\end{array}$} \\
\hline$\underline{\text { Characteristics }}$ & $\frac{\text { Number of Storm }}{\underline{\text { Sewersheds }}}$ \\
\hline \multicolumn{2}{|c|}{ Ponds $\bar{\square}$} \\
\hline Present & 6 \\
\hline Absent & 12 \\
\hline \multicolumn{2}{|c|}{ Sump Pumps } \\
\hline Present & 9 \\
\hline Absent & 9 \\
\hline \multicolumn{2}{|c|}{ Primary Zoning } \\
\hline Commercial & 6 \\
\hline Residential & 11 \\
\hline Other & 1 \\
\hline \multicolumn{2}{|c|}{ Percent Impervious Surface } \\
\hline$<15 \%$ & 2 \\
\hline $15-30 \%$ & 6 \\
\hline $30-40 \%$ & 6 \\
\hline $40-75 \%$ & 4 \\
\hline \multicolumn{2}{|c|}{ Pipe Diameter (cm) } \\
\hline $30-40$ & 4 \\
\hline $40-70$ & 6 \\
\hline $70-100$ & 2 \\
\hline $100-150$ & 3 \\
\hline $150+$ & 3 \\
\hline
\end{tabular}

Storm sewer density was calculated by dividing the number of storm sewer miles in a storm sewershed by its total area. Percent impervious surface cover was extracted for each storm sewershed from the City of Bloomington's data layer and manual digitization using our delineated area. This result was divided by the storm sewershed's total area.

Each storm sewershed had several zoning classifications (residential, commercial, open space/parkland). Component parts of the watershed for zoning was determined using the same method as \%ISC. Roads in the city of Bloomington were not assigned a zoning classification, however they are considered important in this study because 
stormwater was directed to roadways to be efficiently transported to the storm sewer. Therefore, the zoning percentage of each storm sewershed was compared to its total area and any cells not assigned a zoning classification were assumed to be a roadway and a percentage of road was calculated as the remaining percentage.

\section{Precipitation and Discharge}

Daily precipitation totals were downloaded from the National Climatic Data Center. We assumed even precipitation for all storm sewersheds. For six events, storm sewer flow was driven by rainfall. An average precipitation value was calculated from the five surrounding weather stations: US1ILMCL017, US1ILMCL018, USC0011076, US1ILMCL023, USC00110764. For one event (Feb 2015), flow was derived from snowmelt. The snow depth was recorded for the sampling date as an average from the same five stations. Conditions surrounding snowmelt-driven flow events can be very different than those of rainfall events based on the snow temperature, snow density, heat flux etc. (Garen and Marks, 2005). Therefore, we treated this snowmelt event separately and did not combine it with the rainfall-driven events.

Water depth measurements of the stormwater were taken at the time of sampling. Depth measurements were unavailable for the June $8^{\text {th }}$ and December $15^{\text {th }}$ sampling events. Manning's equation was used to determine instantaneous discharge $\left(\mathrm{Q}_{\mathrm{t}}, \mathrm{Ls}^{-1}\right)$ :

$$
Q_{t}=A \frac{1000}{n} R^{\frac{2}{3}} S^{\frac{1}{2}}
$$

Where $A$ is the cross sectional area based on depth and pipe diameter, $n$ is the hydraulic radius and $s$ is the energy slope. Most study sites are reinforced concrete and an $n$ value of 0.012 was chosen (ACPA, 2012). Slope $(s)$ was determined with a Brunton compass at the pipe outlet. 
Stormwater Collection and Analysis

We collected manual grab samples from the outlets of each storm sewer system. Details of each storm sewershed locations and site description are available in Appendix C. Samples were collected in 1L HPDE Nalgene bottles as well as in situ measurements with an YSI ProPlus for $\mathrm{pH}$, dissolved oxygen, temperature and specific conductivity. Samples were collected during six distinct storm events and one snowmelt event (Table 5). One sample was associated with each storm sewershed during each storm event.

Sampling from all storm sewers was completed within approximately a 3-hour time frame for each event. Samples were placed in a dark chilled cooler $\left(\sim 4^{\circ} \mathrm{C}\right)$ and taken to the laboratory for processing. Storm sewers were not always sampled in the same order. In some cases we worked east to west and in other west to east. The direction primarily depended on the size of the storm. The storm sewer systems in the west are

\begin{tabular}{|cc|}
\hline \multicolumn{2}{|l|}{ Table 5} \\
Precipitation Magnitude & When Samples Were Taken \\
\hline \multicolumn{3}{|c|}{ Sample Date } & Precipitation (mm) \\
$5 / 9 / 14$ & 6.5 \\
$6 / 8 / 14$ & 45.9 \\
$6 / 10 / 14$ & 4.0 \\
$7 / 25 / 14$ & $\mathrm{ND}$ \\
$9 / 15 / 14$ & $\mathrm{ND}$ \\
$12 / 15 / 14$ & 0.7 \\
$2 / 7 / 15^{*}$ & 13.5 \\
\hline $\mathrm{ND}=$ Non-Detection & \\
& \\
*The February 2015 precipitation measurement is & \\
the depth of snow recorded on the sampling date
\end{tabular}


small and carry less water. When storms were large, we would visit the large sites first in case of flooding. For small events, we would visit small locations first before the storm sewers dried up.

We used pre-combusted $1.5 \mu \mathrm{m}$ glass fiber filters (Whatman 934-AH) to filter samples for total suspended solid (TSS) and volatile suspended solids (VSS) analysis using the loss ignition method (ASTM, 2000). A second filtration at $1 \mu \mathrm{m}$ (Pall Corporation $\mathrm{A} / \mathrm{E}$ ) with another glass fiber filter was used prepare samples for nutrient analysis. Chloride concentrations were determined on a Dionex ISC 1100 ion chromatograph. Ammonia, nitrate, and dissolved reactive phosphorous (DRP) were determined by Latchat QuikChem 8500 flow injection analysis. Total phosphorus was determined by digestion followed by Latchat QuikChem 8500 flow injection analysis for dissolved reactive phosphorus.

\section{Statistical Analysis}

Statistical analyses were performed in JMP 10.0 software (SAS, 2012). We compared solute concentrations, solute loads, and specific conductivity across sites, primary zoning, primary land cover, dates, presence or absence of ponds and presence or absence of sump pumps using an ANOVA followed by a post-hoc Tukey-Kramer means test. Data were log transformed to normalize data as necessary to meet assumptions of homogeneity of variance. We used pairwise correlations to identify correlation among solute concentrations, solute loads and specific conductivity against area, percent impervious surface cover, storm sewer pipe miles, storm sewer pipe density, and inlet density. 
Storm sewershed areas ranged from $184.7 \mathrm{~m}^{2}$ to over $2 \mathrm{~km}^{2}$. The derived area was positively correlated with the number of inlets $(\mathrm{p}<0.0001)$ and length of storm sewer pipe $(\mathrm{p}<0.005)$. Unlike natural water catchments, storm sewersheds were not always

continuous (see Figure 3). Sources of error included overestimation based on flood routes and underestimation based on sinks and horizontal error between elevation data and inlet data (see Chapter 2).

\section{Results}

Our samples had a high degree of variability. Factors such as the season (Table 6), precipitation (Table 7) both affected the concentrations of our parameters but we were unable to account for such variation due to limitations in the project.

\section{Concentrations}

Storm sewersheds with a pond present had significantly better water quality than storm sewersheds without ponds. The storm sewersheds with ponds had significantly lower specific conductivity $(\mathrm{p}<0.05)$, TSS $(\mathrm{p}<0.0005)$, VSS $(\mathrm{p}<0.005)$, DRP $(\mathrm{p}<0.05)$, nitrate $(\mathrm{p}<0.05)$ (Figure 13). The percentage of organic matter was higher in the storm sewersheds with a pond $(\mathrm{p}<0.05)$. 


\begin{tabular}{|c|c|c|c|c|}
\hline \multicolumn{5}{|c|}{\begin{tabular}{|l} 
Table 6 \\
Mean Concentrations by Precipitation Magnitude.
\end{tabular}} \\
\hline \multirow[t]{3}{*}{ 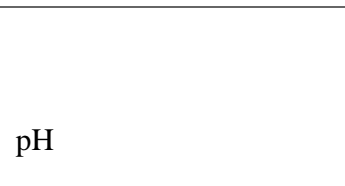 } & \multirow{3}{*}{$\begin{array}{l}\frac{\text { Less than }}{\leq 1 \mathrm{~mm}} \\
\frac{7.96}{(7.75-8.17)}\end{array}$} & \multirow{3}{*}{$\begin{array}{l}\frac{\text { Medium }}{\text { Precipitation }} \\
7.80 \\
(7.72-7.87)\end{array}$} & \multirow{2}{*}{$\frac{\text { High }}{\text { Precipitation }}$} & \multirow[t]{2}{*}{$\underline{\text { Snowmelt }}$} \\
\hline & & & & \\
\hline & & & $\begin{array}{l}\overline{7.64} \\
(7.2-8.02)\end{array}$ & $\begin{array}{l}7.21 \\
(6.79-7.63)\end{array}$ \\
\hline $\begin{array}{l}\text { Specific Conductivity } \\
(\mu \mathrm{S} / \mathrm{cm})\end{array}$ & $\begin{array}{l}398 \\
(311-510)\end{array}$ & $\begin{array}{l}815 \\
(665-1000)\end{array}$ & $\begin{array}{l}1224 \\
(967-1549)\end{array}$ & $\begin{array}{l}3550 \\
(2505-5030)\end{array}$ \\
\hline Dissolved Oxygen (\%) & $\begin{array}{l}102 \\
(97-108)\end{array}$ & $\begin{array}{l}86 \\
(81-91)\end{array}$ & $\begin{array}{l}85 \\
(80-90)\end{array}$ & $\begin{array}{l}85 \\
(80-90)\end{array}$ \\
\hline $\begin{array}{l}\text { Total Suspended Solids } \\
(\mathrm{mg} / \mathrm{L})\end{array}$ & $\begin{array}{l}18.08 \\
(12.95-25.24)\end{array}$ & $\begin{array}{l}10.06 \\
(7.41-13.66)\end{array}$ & $\begin{array}{l}3.57 \\
(2.28-5.58)\end{array}$ & $\begin{array}{l}99.80 \\
(49.84-199.84)\end{array}$ \\
\hline $\begin{array}{l}\text { Total Suspended Solids } \\
(\mathrm{mg} / \mathrm{s})\end{array}$ & $\begin{array}{l}2.28 \\
(0.87-5.96)\end{array}$ & $\begin{array}{l}0.71 \\
(0.16-3.16)\end{array}$ & & $\begin{array}{l}3.5 \\
(0.44-27.71)\end{array}$ \\
\hline $\begin{array}{l}\text { Volatile Suspended } \\
\text { Solids (mg/L) }\end{array}$ & $\begin{array}{l}6.18 \\
(4.70-8.12)\end{array}$ & $3.75(2.87-4.88)$ & $\begin{array}{l}1.23 \\
(0.82-1.85)\end{array}$ & $\begin{array}{l}31.65 \\
(16.73-59.88)\end{array}$ \\
\hline $\begin{array}{l}\text { Volatile Suspended } \\
\text { Solids }(\mathrm{mg} / \mathrm{s})\end{array}$ & $\begin{array}{l}0.79 \\
(0.30-2.11)\end{array}$ & $\begin{array}{l}0.33 \\
(0.08-1.34)\end{array}$ & & $\begin{array}{l}1.17 \\
(0.15-9.36)\end{array}$ \\
\hline Percent Organics & $\begin{array}{l}34.37 \\
(30.67-38.56)\end{array}$ & $\begin{array}{l}39.11 \\
(35.13-43.56)\end{array}$ & $\begin{array}{l}34.47 \\
(25.87-45.93)\end{array}$ & $\begin{array}{l}31.71 \\
(27.67-36-35)\end{array}$ \\
\hline Total Phosphorous $(\mu \mathrm{g} / \mathrm{L})$ & $\begin{array}{l}79.18 \\
(63.46-98.79)\end{array}$ & $\begin{array}{l}42.68 \\
(30.81-59.11)\end{array}$ & $\begin{array}{l}34.83 \\
(23.81-50.95)\end{array}$ & $\begin{array}{l}126.10 \\
(88.57-179.54)\end{array}$ \\
\hline Total Phosphorous $(\mu \mathrm{g} / \mathrm{s})$ & $\begin{array}{l}11.90 \\
(3.99-35.42)\end{array}$ & $\begin{array}{l}6.12 \\
(1.06-35.34)\end{array}$ & & $\begin{array}{l}4.32 \\
(0.51-36.51)\end{array}$ \\
\hline $\begin{array}{l}\text { Dissolved Reactive } \\
\text { Phosphorous }(\mu \mathrm{g} / \mathrm{L})\end{array}$ & $\begin{array}{l}55.09 \\
(39.96-75.94)\end{array}$ & $\begin{array}{l}15.59 \\
(11.30-21.51)\end{array}$ & $\begin{array}{l}8.06 \\
(4.52-14.37)\end{array}$ & $\begin{array}{l}30.81 \\
(20.76-45.72)\end{array}$ \\
\hline $\begin{array}{l}\text { Dissolved Reactive } \\
\text { Phosphorous }(\mu \mathrm{g} / \mathrm{s})\end{array}$ & $\begin{array}{l}8.05 \\
(2.62-24.75)\end{array}$ & $\begin{array}{l}1.31 \\
(0.31-5.61)\end{array}$ & & $\begin{array}{l}0.99 \\
(0.10-9.63)\end{array}$ \\
\hline Ammonia (mg/L) & $\begin{array}{l}0.120 \\
(0.100-0.145)\end{array}$ & $\begin{array}{l}0.054 \\
(0.038-0.077)\end{array}$ & $\begin{array}{l}0.022 \\
(0.015-0.030)\end{array}$ & $\begin{array}{l}0.140 \\
(0.092-0.213)\end{array}$ \\
\hline Ammonia (mg/s) & $\begin{array}{l}0.019 \\
(0.006-0.058)\end{array}$ & $\begin{array}{l}0.004 \\
(0.001-0.018)\end{array}$ & & $\begin{array}{l}0.004 \\
(<0.0001-0.047)\end{array}$ \\
\hline Nitrate (mg/L) & $\begin{array}{l}0.78 \\
(0.65-0.94)\end{array}$ & $\begin{array}{l}0.91 \\
(0.72-1.16)\end{array}$ & $\begin{array}{l}1.40 \\
(0.76-2.58)\end{array}$ & $\begin{array}{l}0.63 \\
(0.5-0.79)\end{array}$ \\
\hline Nitrate (mg/s) & $\begin{array}{l}0.10 \\
(0.03-0.29)\end{array}$ & $\begin{array}{l}0.08 \\
(0.02-0.32)\end{array}$ & & $\begin{array}{l}0.02 \\
(<0.01-0.21)\end{array}$ \\
\hline Chloride (mg/L) & $\begin{array}{l}76.91 \\
(60.23-98.20)\end{array}$ & $\begin{array}{l}145.74 \\
(114.35-185.75)\end{array}$ & $\begin{array}{l}174.62 \\
(124.47-246.98)\end{array}$ & $\begin{array}{l}1356.40 \\
(931.22-1975.74)\end{array}$ \\
\hline Chloride (mg/s) & $\begin{array}{l}10.37 \\
(3.38-31.83) \\
\end{array}$ & $\begin{array}{l}12.45 \\
(3.15-49.18)\end{array}$ & & $\begin{array}{l}46.96 \\
(5.59-394-30)\end{array}$ \\
\hline (95\% Confidence & erval) & & & \\
\hline
\end{tabular}




\begin{tabular}{|c|c|c|c|c|}
\hline \multicolumn{5}{|c|}{$\begin{array}{l}\text { Table } 7 \\
\text { Mean Concentrations by Season }\end{array}$} \\
\hline & Spring & $\underline{\text { Summer }}$ & Fall & Winter \\
\hline $\mathrm{pH}$ & $\begin{array}{l}7.84 \\
(7.73-7.96)\end{array}$ & 7.70(7.50-7.89) & $8.22(7.91-8.54)$ & $\begin{array}{l}\overline{7.41} \\
(7.18-7.64)\end{array}$ \\
\hline Temperature $\left({ }^{\circ} \mathrm{C}\right)$ & $\begin{array}{l}15.4 \\
(14.4-16.4)\end{array}$ & $18.5(17.9-19.0)$ & $16.5(16.2-16.9)$ & $6.2(5.2-7.2)$ \\
\hline Specific Conductivity $(\mu \mathrm{S} / \mathrm{cm})$ & $\begin{array}{l}1014 \\
(795-1296)\end{array}$ & $763(618-942)$ & $294(190-455)$ & $\begin{array}{l}1292 \\
(823-2027)\end{array}$ \\
\hline Dissolved Oxygen (\%) & $85(76-97)$ & $93(88-99)$ & $86(82-89)$ & $\begin{array}{l}114 \\
(109-119)\end{array}$ \\
\hline Total Suspended Solids (mg/L) & $\begin{array}{l}12.11 \\
(8.38-17.50)\end{array}$ & $7.28(5.35-9.90)$ & $\begin{array}{l}13.63 \\
(7.40-25.09)\end{array}$ & $\begin{array}{l}56.56 \\
(34.65-91.33)\end{array}$ \\
\hline Total Suspended Solids (mg/s) & $\begin{array}{l}0.69 \\
(0.06-8.32)\end{array}$ & $\begin{array}{l}0.97 \\
(0.30-3.11)\end{array}$ & $\begin{array}{l}3.48 \\
(0.77-15.69)\end{array}$ & $\begin{array}{l}3.39 \\
(0.57-20.14)\end{array}$ \\
\hline Volatile Suspended Solids (mg/L) & $\begin{array}{l}4.57 \\
(3.27-6.37)\end{array}$ & $\begin{array}{l}2.77 \\
(2.09-3.68)\end{array}$ & $\begin{array}{l}4.02 \\
(2.67-6.05)\end{array}$ & $\begin{array}{l}17.94 \\
(11.58-27.77)\end{array}$ \\
\hline Volatile Suspended Solids (mg/s) & $\begin{array}{l}0.27 \\
(0.02-3.18)\end{array}$ & $\begin{array}{l}0.45 \\
(0.14-1.39)\end{array}$ & $\begin{array}{l}1.04 \\
(0.23-4.76)\end{array}$ & $\begin{array}{l}1.16 \\
(0.19-7.01)\end{array}$ \\
\hline Percent Organics & $38(32-45)$ & $38(34-43)$ & $30(23-38)$ & $33(30-36)$ \\
\hline Total Phosphorous $(\mu \mathrm{g} / \mathrm{L})$ & & $\begin{array}{l}46.75 \\
(36.79-59.41)\end{array}$ & $\begin{array}{l}65.72 \\
(47.72-90.51)\end{array}$ & $\begin{array}{l}109.42 \\
(86.52- \\
138.38)\end{array}$ \\
\hline Total Phosphorous $(\mu \mathrm{g} / \mathrm{s})$ & & $\begin{array}{l}6.82 \\
(1.99-23.40)\end{array}$ & $\begin{array}{l}16.91 \\
(3.28-87.15)\end{array}$ & $\begin{array}{l}4.44 \\
(0.69-28.52)\end{array}$ \\
\hline $\begin{array}{l}\text { Dissolved Reactive Phosphorous } \\
(\mu \mathrm{g} / \mathrm{L})\end{array}$ & $\begin{array}{l}17.23 \\
(10.77-27.58)\end{array}$ & $\begin{array}{l}17.00(11.52- \\
25.10)\end{array}$ & $\begin{array}{l}45.54(25.92- \\
80.00)\end{array}$ & $\begin{array}{l}46.81 \\
(34.50-63.52)\end{array}$ \\
\hline $\begin{array}{l}\text { Dissolved Reactive Phosphorous } \\
(\mu \mathrm{g} / \mathrm{s})\end{array}$ & $\begin{array}{l}0.85 \\
(0.07-9.76)\end{array}$ & $\begin{array}{l}2.73 \\
(0.81-9.24)\end{array}$ & $\begin{array}{l}14.63 \\
(2.48-86.46)\end{array}$ & $\begin{array}{l}1.26 \\
(0.17-9.36)\end{array}$ \\
\hline Ammonia (mg/L) & $\begin{array}{l}0.065 \\
(0.036-0.120)\end{array}$ & $\begin{array}{l}0.049 \\
(0.037-0.065)\end{array}$ & $\begin{array}{l}0.106 \\
(0.076-0.147)\end{array}$ & $\begin{array}{l}0.131 \\
(0.101-0.169)\end{array}$ \\
\hline Ammonia (mg/s) & $\begin{array}{l}0.003 \\
(<0.001-0.003)\end{array}$ & $\begin{array}{l}0.008 \\
(0.002-0.027)\end{array}$ & $\begin{array}{l}0.036 \\
(0.006-0.217)\end{array}$ & $\begin{array}{l}0.005 \\
(0.001-0.037)\end{array}$ \\
\hline Nitrate (mg/L) & $\begin{array}{l}0.99 \\
(0.70-1.40)\end{array}$ & $\begin{array}{l}1.11 \\
(0.85-1.46)\end{array}$ & $\begin{array}{l}0.51 \\
(0.39-0.67)\end{array}$ & $\begin{array}{l}0.71 \\
(0.61-0.82)\end{array}$ \\
\hline Nitrate $(\mathrm{mg} / \mathrm{s})$ & $\begin{array}{l}0.06 \\
(0.01-0.56)\end{array}$ & $\begin{array}{l}0.10 \\
(0.03-0.33)\end{array}$ & $\begin{array}{l}0.13 \\
(0.02-0.64)\end{array}$ & $\begin{array}{l}0.03 \\
(<0.01-0.18)\end{array}$ \\
\hline Chloride (mg/L) & $\begin{array}{l}209.07 \\
(150.39- \\
290.67)\end{array}$ & $\begin{array}{l}131.35 \\
(107.14-161.03)\end{array}$ & $\begin{array}{l}40.63 \\
(29.58-55.81)\end{array}$ & $\begin{array}{l}371.70 \\
(223.45- \\
618.32)\end{array}$ \\
\hline Chloride (mg/s) & $\begin{array}{l}11.81 \\
(1.12-124.57)\end{array}$ & $\begin{array}{l}12.28 \\
(3.66-41.24)\end{array}$ & $\begin{array}{l}11.51 \\
(2.25-59.03)\end{array}$ & $\begin{array}{l}34.03 \\
(4.62-250.66)\end{array}$ \\
\hline
\end{tabular}




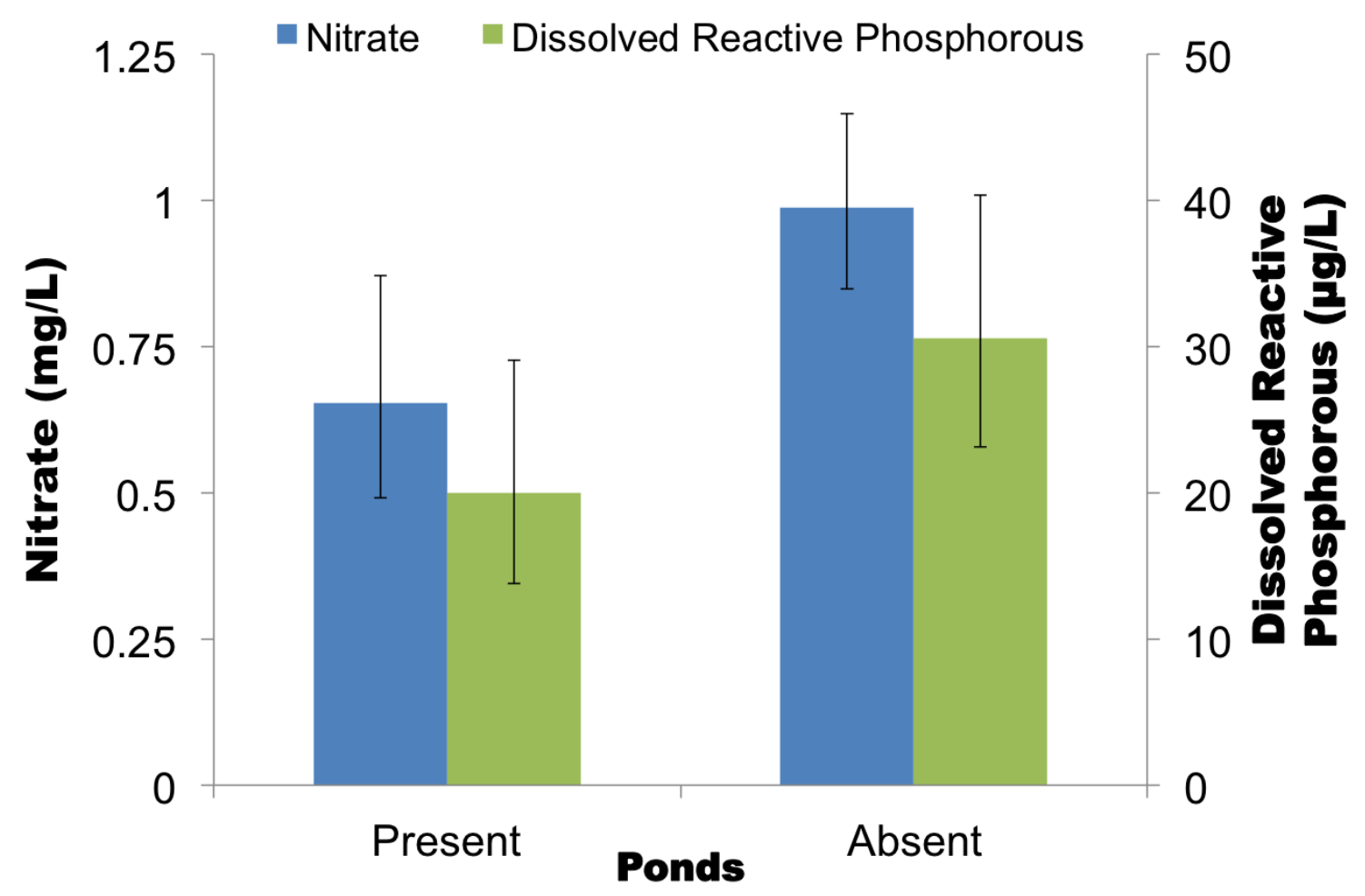

Figure 13. Storm Sewersheds with Ponds had Better Stormwater Quality. The concentration of nitrate (blue) and DRP (green) were lower in storm sewersheds with ponds than storm sewersheds without ponds $(\mathrm{p}<0.01$ and $\mathrm{p}<0.05$ respectively). Error bars are the $95 \%$ confidence interval.

The percent impervious surface cover varied from 10-70\% among the storm sewersheds and as the percentage increased the water quality was more degraded. Chloride concentration increased as \% ISC increased $\left(\mathrm{p}<0.05, \mathrm{r}^{2}=0.03\right)$ (Figure 14).

The nine storm sewersheds with sump pumps had significantly different water quality. The percentage of organic matter was higher in storm sewersheds with sump pumps present $(\mathrm{p}<0.005)$. Storm sewersheds with sump pumps also had significantly lower chloride concentrations $(\mathrm{p}<0.0001)$.

The percentage of some zoning classification had an impact on water quality. As the percentage of commercial area increased within a storm sewershed the water quality became less degraded. The TSS, VSS, and total phosphorous concentrations decreased as 


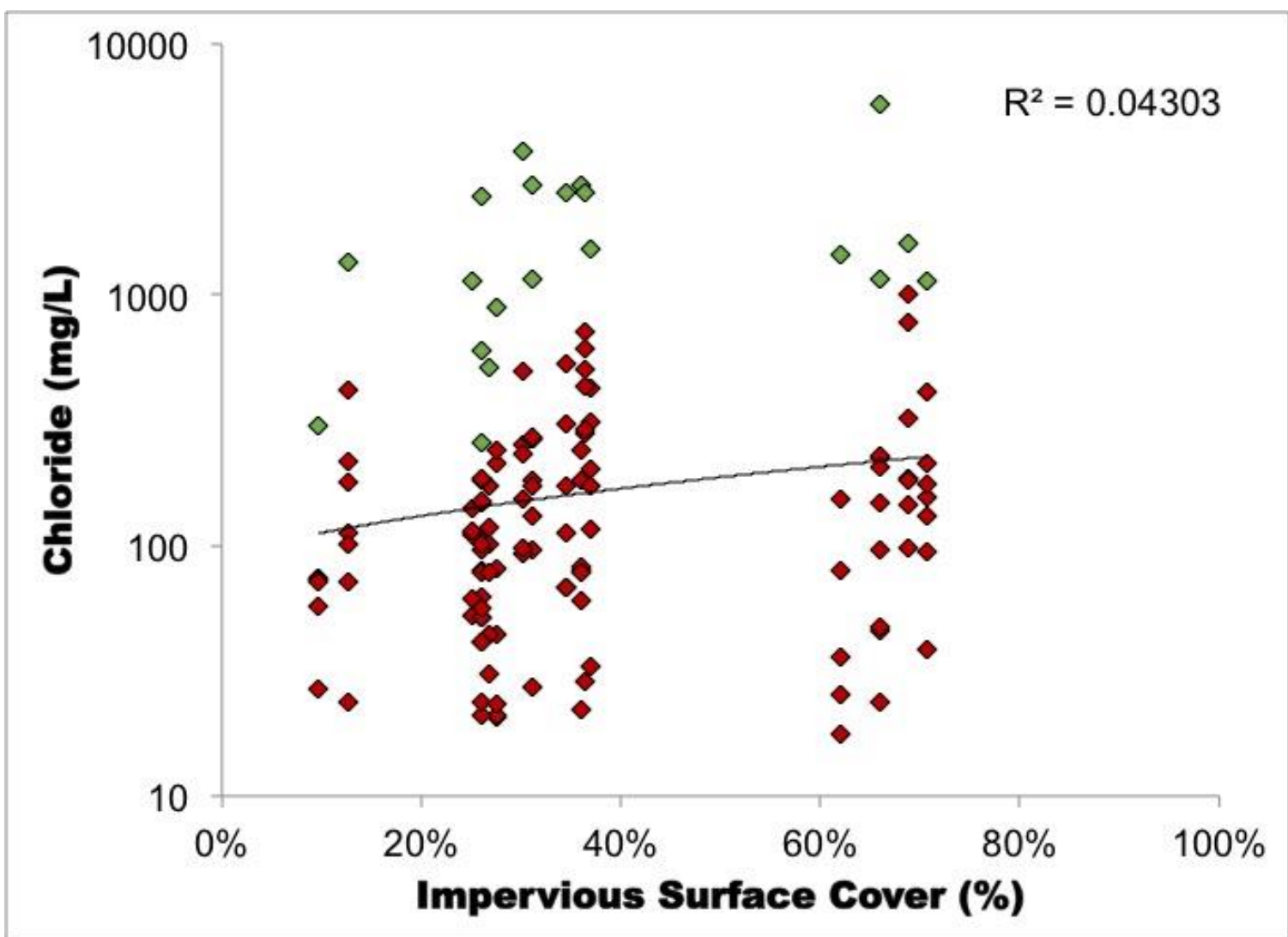

Figure 14. Chloride Concentrations were Positively Correlated with Impervious Surface Cover. When the snowmelt (Feb 2015) was excluded the chloride concentrations decreased as the \%ISC increased $(\mathrm{p}<0.05)$. The green data points are from the excluded snowfall event for reference.

the percentage of commercial area increased $\left(\mathrm{p}<0.05, \mathrm{r}^{2}=0.04 ; \mathrm{p}<0.0005, \mathrm{r}^{2}=0.055\right.$ and $\mathrm{p}<0.05, \mathrm{r}^{2}=0.047$ respectively). The percentage of residential area had a negative impact on water quality. As the percent of residential area increased the VSS increased $(p<0.05$, $\left.r^{2}=0.049\right)$. 


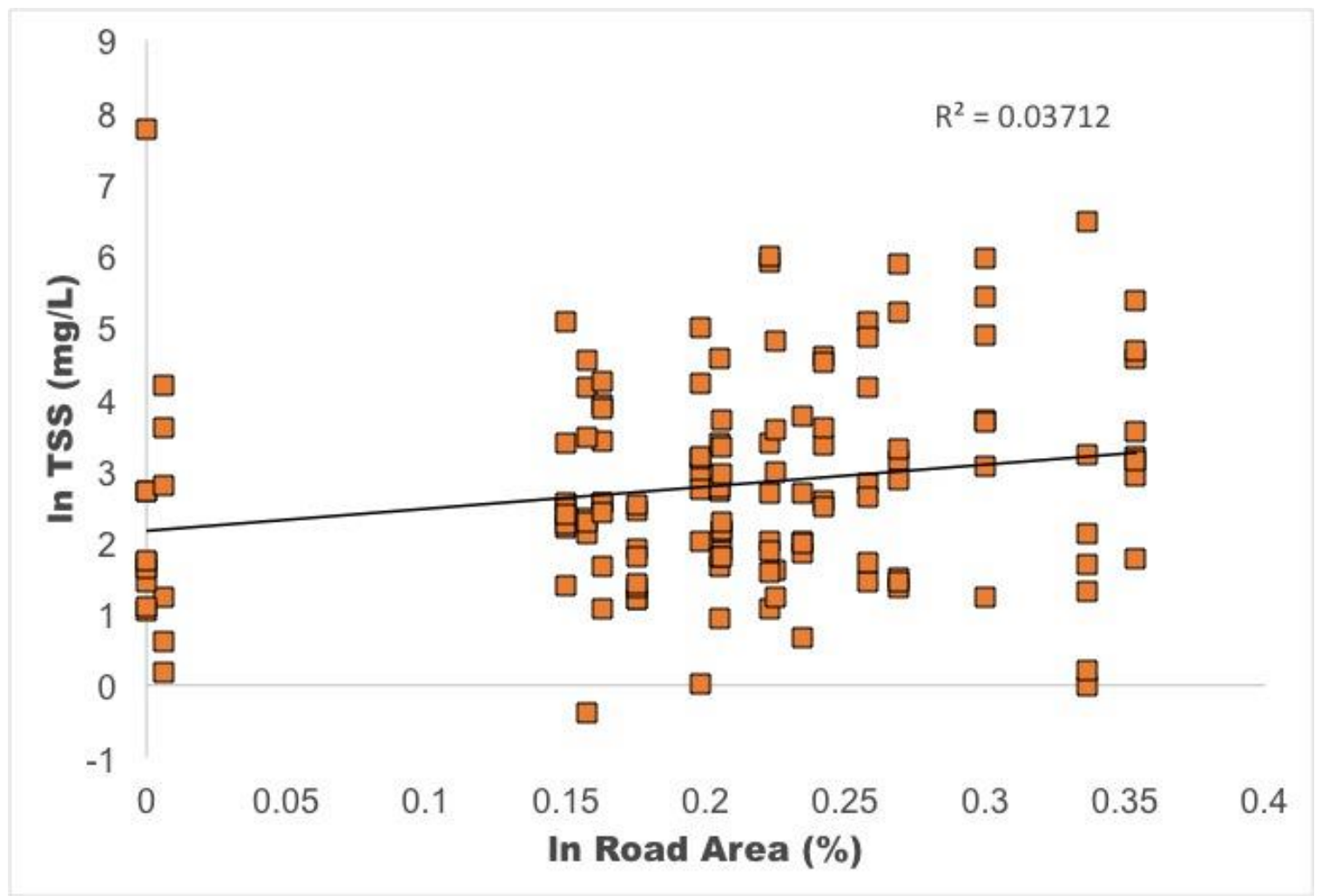

Figure 15. Total Suspended Solid Concentrations were Positively Correlated with Percent Road Area. As the percent of road increased the total suspended solids concentration also increased $(\mathrm{p}<0.05)$

The percentage of road area within a storm sewershed had a significant impact on water quality. Roads are designed to be the surface conduits for storm water until it reaches an inlet. Thus, they are where the flow of runoff is likely to be the strongest, especially along the curb. The percentage of road within the storm sewersheds ranged from $0-42 \%$ with a median of $23 \%$. As the percentage of road area increased within the storm sewershed, TSS and VSS increased $\left(\mathrm{p}<0.05, \mathrm{r}^{2}=0.053\right.$ and $\mathrm{p}<0.0005, \mathrm{r}^{2}=0.030$ respectively) (Figure 15).

The layout of the pipes in a storm sewer system has a significant impact on water quality. The length of the pipe within a storm sewershed showed trends with $\mathrm{pH}$ and dissolved oxygen. As the pipe length increased $\mathrm{pH}$ decreased $\left(\mathrm{p}<0.05, \mathrm{r}^{2}=0.05\right)$, which is 
contrary to findings by Davies et al. (2010). The percentage of dissolved oxygen also decreased $\left(\mathrm{p}<0.05, \mathrm{r}^{2}=0.04\right)$ as the pipe length increased. Increasing pipe density had a beneficial impact on water quality. The greater the density of the pipes, the lower the concentrations of TSS $\left(\mathrm{p}<0.05, \mathrm{r}^{2}=0.039\right)$ and $\operatorname{VSS}\left(\mathrm{p}<0.05, \mathrm{r}^{2}=0.033\right)$.

The nine storm sewer sheds with sump pumps had significantly better water quality than those without sump pump (Figure 16). Concentrations of chloride were significantly lower in storm sewer sheds with chloride, this may be due to dilution by the subsurface water that sump pumps contribute.

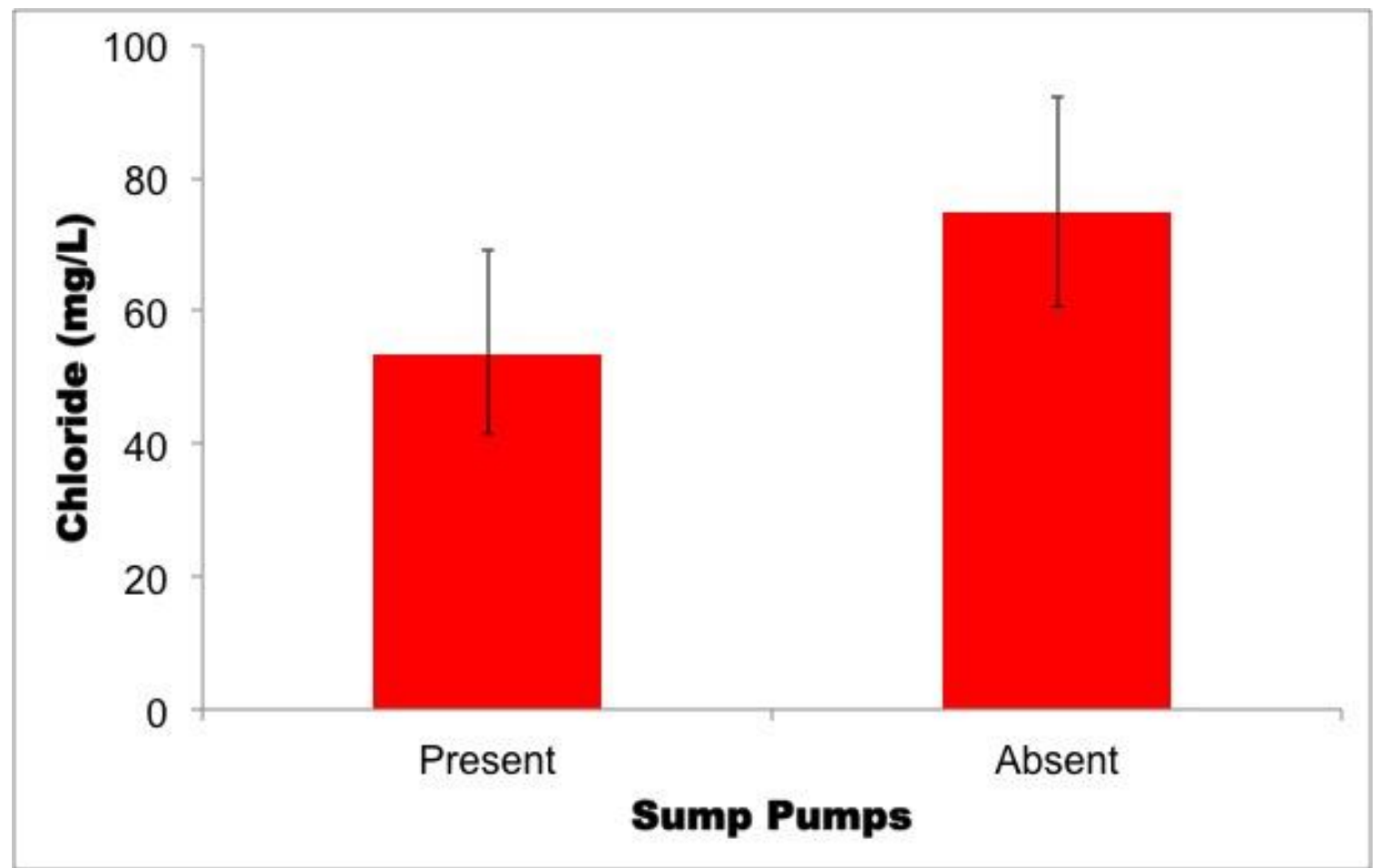

Figure 16. Storm Sewersheds with Sump Pumps had Better Stormwater Quality. The concentration of chloride was significantly lower in storm sewer sheds with sump pumps present. Error bars are 95\% confidence interval.

Mass Flux

The area of the storm sewershed had a significant effect on the chemical mass flux. The greater the area the more mass per time will enter the stream for the following: 
TSS $\left(\mathrm{p}<0.0005, \mathrm{r}^{2}=0.225\right), \operatorname{VSS}\left(\mathrm{p}<0.0005, \mathrm{r}^{2}=0.269\right), \operatorname{DRP}\left(\mathrm{p}<0.005, \mathrm{r}^{2}=0.229\right)$, ammonia $\left(\mathrm{p}<0.005, \mathrm{r}^{2}=0.255\right)$, nitrate $\left(\mathrm{p}<0.05, \mathrm{r}^{2}=0.188\right)$, total phosphorous $(\mathrm{p}<0.0005$, $\left.\mathrm{r}^{2}=0315\right)$ and chloride $\left(\mathrm{p}<0.0005, \mathrm{r}^{2}=0.169\right)$. Other physical characteristics including pipe length and the presence of a pond or sump pumps have similar relationships. The similarities only occurred for mass flux, not concentrations. However, we suspect that these relationships are artifacts of the storm sewershed area. Pipe length was directly related to the area of storm sewershed size $\left(\mathrm{p}<0.0001, \mathrm{r}^{2}=0.854\right.$; Chapter 2$)$. Sump pumps and ponds also occur in larger storm sewersheds.

Increased \%ISC increased the mass flux of some contaminants from storm sewersheds. The greater the \%ISC, the more nitrate $\left(\mathrm{p}<0.05, \mathrm{r}^{2}=0.06\right)$ and chloride $\left(\mathrm{p}<0.05, \mathrm{r}^{2}=0.05\right)$ exited the system per second.

Zoning classifications had an impact on the mass flux of contaminants from storm sewersheds. The greater the percentage of commercial zoning in a storm sewershed the more nitrate leaves the system $\left(\mathrm{p}<0.05, \mathrm{r}^{2}=0.068\right)$. The storm sewersheds with higher residential zoning have a lower mass of nitrate leaving the system per second $(\mathrm{p}<0.05$, $\left.\mathrm{r}^{2}=0.061\right)$. The greater the percentage of road in the storm sewershed, the lower the mass flux of the following: DRP $\left(\mathrm{p}<0.05, \mathrm{r}^{2}=0.066\right)$, nitrate $\left(\mathrm{p}<0.05, \mathrm{r}^{2}=0.081\right)$, total phosphorous $\left(\mathrm{p}<0.0005, \mathrm{r}^{2}=0.072\right)$ and chloride $\left(\mathrm{p}<0.0001, \mathrm{r}^{2}=0.077\right)$.

\section{Discussion}

The size of the storm sewer system does represent the magnitude of the mass flux of solutes. Miller et al. (2014) reported that in a peri-urban catchment the size of the storm sewershed was a determining factor in the scale runoff response and the volume of water does not appear to offer dilution especially since stormwater concentrations are so 
variable. Therefore larger storm sewersheds output a greater mass per time. The large storm sewersheds are also constantly flowing due to a combination of sump pumps and ponds. Only in rare cases do small storm sewersheds have large mass flux (for example chloride) during the snowmelt event.

Our findings suggest that the presence of a pond significantly improves storm water quality. These findings are consistent with literature documenting changes in water quality after flowing through a pond (Herrman, 2012; Marsalek, 2002; Tixier, 2001). The observation of reduced solute concentrations measured in this study demonstrated that some treatment likely occurs within ponds.

Treatment within ponds was likely a factor of their discharge control properties and flora present within each system. The original purpose of pond was to slow storm water flow, this process in turn allows for suspended solids to settle out (Welty, 2009). The increase in $\%$ organic matter was likely also result of this process. Organic matter may have been less likely to settle out even in slower moving waters. It would also be possible that organic matter was picked up in ponds, especially retention ponds where phytoplankton can grow. The reduction of levels in other parameters is likely due in part to the settling of solids on which these parameters were absorbed (Tixier, 2011). Flora in the pond area may also react with the nutrients in the stormwater (Herrman, 2012).

Parking lots appear to contribute large amounts of chloride. If the road salt spread on roads was the primary contributor of chloride, then percentage of road area would also be correlated with chloride. However, businesses may distribute more road salt than is necessary to prevent slippery surfaces in an effort to prevent liability for injury. The frequency of use of an impervious surface could have affected chemistry just as physical 
characteristics did (Gallo et al. 2013). A catchment may have high \% ISC but if it is not used often that may affect the particulates present on the surface and how they move. This is why we may not see significance with all parameters in relation to \% ISC. This is not to say that the water quality is not degraded. Rather it is simply that as impervious surface cover varies throughout an urban area it does not necessarily change the water quality.

Storm sewersheds with high \%ISC have higher mass flux of nitrate and chloride either due to increased supply or increased transportation. In the case of chloride it is most likely an increase in supply since road salt is only placed on impervious surfaces. Nitrate however is primarily spread on pervious surfaces as fertilizer. If runoff over pervious surface is the source then the increase in \%ISC simply aids in the transportation of nitrate to the storm sewer (Hatt et al., 2004, Hale et al., 2014).

Our study suggests that the higher the percentage of road, the more degraded the water quality. Road were important to storm water management because they are the conduits for the storm water. A greater percentage of roads could lead to stronger flow of runoff before it gets to the storm sewer inlet. Like water accumulated at the curb of the road, debris may have accumulated there as well. Higher flows would lead to the possibility of more solids becoming suspended, and increased debris would increase the availability of solids to be picked up.

The decrease in $\mathrm{pH}$ relative to increasing pipe length is contrary to previous literature (Davies et al. 2010). The calcium and bicarbonate in the cement of the pipes should increase the $\mathrm{pH}$ with more contact. However, Davies et al. (2010) did state that this effect is reduced as the pipes age and degrade. Perhaps the age of the Bloomington 
system is such that it does not raise the $\mathrm{pH}$ and some other factor is lowering the $\mathrm{pH}$ with extended contact with the pipes.

We observed better water quality with denser pipe systems, probably because water spent less time on the surface. In other words, the denser the piping system the shorter the distance the water would have to travel on the surface and less opportunity to be pick up solids and with less power to pick up the larger particles. Pipe density did not seem to have significance with nutrients (Hale et al. 2014). Although it is curious that inlet density did not show the same relationships as pipe density. It is possible that there were inlets missing from the data set. There were inlets within a storm sewer system that contribute to other systems when flood routes were present (see Chapter 2). These inlets were not incorporated in our calculations.

The availability of all suspended solids and total phosphorous was less in commercial areas. The decrease in total phosphorous may have been due to its tendency to be attached to solids (Wang et al., 2011), so as the concentrations of solids decreased total phosphorous also decreased. Residential areas had lower VSS suggesting a greater availability of organic matter. Mass flux of nitrate is affected by zoning in the opposite manner than suspended solids were, in that commercial area had higher mass flux of nitrate and residential areas had lower mass flux of nitrate. These mixed relationships may again be dependent on the type and degree of use (Gallo et al. 2013) or dependent on the fact that solids are available throughout the year and at a relatively constant rate (Brodie, 2007) but nitrate was seasonal (Shertzer et al., 1998). Additionally, Kim et al. (2014) suggest that peak concentrations occur at different points in the hydrograph for commercial and residential catchments. If this is the case, our study would be insufficient 
to make conclusions on the differences in water quality among different zoning percentages since we collected only one grab sample.

Sump pumps appeared to have a diluting effect on conservative ions. Sump pumps draw water from the subsurface (primarily around residential houses), which appears to have minimal amounts chloride in it. The likely source of most chloride comes from road salt spread on impervious surfaces (Kelly, 2008) and subsurface water comes from pervious surfaces. Therefore the sump pumps are likely diluting the chloride. This is supported by O'Reilly et al. (2012), who suggested that chloride concentrations in the subsurface are impacted by preferential flow. It could also suggest that other parameters such as nitrate and DRP percolated through the subsurface since sump pumps were not correlated with those solutes.

\section{Conclusions and Implications}

Our findings suggest that characteristics of storm sewersheds do affect water quality (Table 8). Ponds, sump pumps and higher pipe density improved water quality. Water quality was more degraded by higher \%ISC. The presence of each zoning classification had mixed effects on storm water quality.

Urban areas would likely benefit if ponds were built part of storm sewer systems for the purpose of improving water quality in addition to reducing flow. The ponds reduce the peak flow, beautify the area and improve the water quality. Denser storm sewer design could be considered for new and retrofitted storm sewer systems. Other storm sewershed characteristics are unlikely to be easily incorporated in the storm sewershed design. Impervious surface cover and zoning both change over the years as the urban landscape changes and develops. However, whenever any physical characteristics 
can be considered when designing and building a storm sewer system, water quality could be improved.

\begin{tabular}{|c|c|c|}
\hline \multicolumn{3}{|c|}{$\begin{array}{l}\text { Table } 8 \\
\text { Results of Our a priori Hypotheses }\end{array}$} \\
\hline Physical Characteristic & A priori Hypothesis & Conclusion \\
\hline Ponds & $\begin{array}{l}\text { Presence would improve } \\
\text { water quality }\end{array}$ & $\begin{array}{c}\text { Presence improved water } \\
\text { quality }\end{array}$ \\
\hline $\begin{array}{l}\text { Denser Storm Sewer Pipe } \\
\text { Layout }\end{array}$ & $\begin{array}{l}\text { Positive relationship with } \\
\text { water quality }\end{array}$ & $\begin{array}{l}\text { Positive relationship with } \\
\text { water quality }\end{array}$ \\
\hline Storm sewer pipe length & $\begin{array}{l}\text { Negative Relationship with } \\
\text { water quality }\end{array}$ & Inconclusive \\
\hline$\%$ ISC & $\begin{array}{l}\text { Negative relationship with } \\
\text { water quality }\end{array}$ & $\begin{array}{l}\text { Negative relationship } \\
\text { with water quality }\end{array}$ \\
\hline
\end{tabular}




\section{REFERENCES}

ACPA, 2012, Manning's $n$ values history of research, American Concrete Pipe Association.

Arden, S., Ma, X., and Brown, M., 2014, An ecohydrologic model for a shallow groundwater urban environment: Water Science and Technology, v. 70, no. 11, p. 1789-1797.

Bloschl, G., and Sivapalan, M., 1995, Scale issues in hydrological modeling- A review: Hydrological Processes, v. 9, no. 3-4, p. 251-290.

Brodie, I. M., 2007, Prediction of stormwater particle loads from impervious urban surfaces based on a rainfall detachment index: Water Science and Technology, v. 55 , no. 4, p. 49-56.

Cantone, J., and Schmidt, A., 2011, Improved understanding and prediction of the hydrologic response of highly urbanized catchments through development of the Illinois Urban Hydrologic Model: Water Resources Research, v. 47.

Chang, N. B., and Hernandez, E. A., 2008, Optimal expansion strategy for a sewer system under uncertainty: Environmental Modeling \& Assessment, v. 13, no. 1, p. 93-113.

Choe, J. S., Bang, K. W., and Lee, J. H., 2002, Characterization of surface runoff in urban areas: Water Science and Technology, v. 45, no. 9, p. 249-254.

Chow, M. F., and Yusop, Z., 2014, Characterization and source identification of stormwater runoff in tropical urban catchments: Water Science and Technology, v. 69 , no. 2 , p. $244-252$.

City of Bloomington, 2013, Stormwater and sanitary sewer master plans executive summary: City of Bloomington, Public Report $4 p$

Cohen, J. E., 2003, Human population: The next half century: Science, v. 302, no. 5648, p. 1172-1175.

Crimmens, T., 2006, Ecological Restoration and Management Plan: Bronx River Alliance. 
Cunningham, M. A., O'Reilly, C. M., Menking, K. M., Gillikin, D. P., Smith, K. C., Foley, C. M., Belli, S. L., Pregnall, A. M., Schlessman, M. A., and Batur, P., 2009, The suburban stream syndrome: evaluating landuse and stream impairments in the suburbs: Physical Geography, v. 30, no. 3, p. 269-284.

CWP, and MDDEWMA, 2000, 2000 Maryland stormwater design manual volumes I and II, Volume I and II: Baltimore, MD, Maryland Department of the Environment Water Management Administration.

Davies, P. J., Wright, I. A., Jonasson, O. J., and Findlay, S. J., 2010, Impact of concrete and PVC pipes on urban water chemistry: Urban Water Journal, v. 7, no. 4, p. 233-241.

Elgy, J., Maksimovic, C., and Prodanovic, D., 1993, Matching Standard GIS Packages with Urban Storm Drainage Simulation Software: Application of Geographic Information Systems in Hydrology and Water Resources Management, v. 211, p. 151-160.

Gallo, E. L., Brooks, P. D., Lohse, K. A., and McLain, J. E. T., 2013, Land cover controls on summer discharge and runoff solution chemistry of semi-arid urban catchments: Journal of Hydrology, v. 485, p. 37-53.

Garen, D. C., and Marks, D., 2005, Spatially distributed energy balance snowmelt modelling in a mountainous river basin: estimation of meteorological inputs and verification of model results: Journal of Hydrology, v. 315, no. 1-4, p. 126-153.

Goulden, T., Hopkinson, C., Jamieson, R., and Sterling, S., 2014, Sensitivity of watershed attributes to spatial resolution and interpolation method of LiDAR DEMs in three distinct landscapes: Water Resources Research, v. 50, no. 3, p. 1908-1927.

Graham, L., 2012, Breaklines and Lidar Data: Photogrammetric engineering and remote sensing, v. 78, no. 3, p. 189-191.

Greene, R. G., and Cruise, J. F., 1995, Urban watershed modeling using geographic information systems: Journal of Water Resources Planning and ManagementAsce, v. 121, no. 4, p. 318-325.

Grimm, N. B., Sheibley, R. W., Crenshaw, C. L., Dahm, C. N., Roach, W. J., and Zeglin, L. H., 2005, N retention and transformation in urban streams: Journal of the North American Benthological Society, v. 24, no. 3, p. 626-642.

Hale, R. L., Turnbull, L., Earl, S. R., Childers, D. L., and Grimm, N. B., 2015, Stormwater Infrastructure Controls Runoff and Dissolved Material Export from Arid Urban Watersheds: Ecosystems, v. 18, no. 1, p. 62-75. 
Hatt, B. E., Fletcher, T. D., Walsh, C. J., and Taylor, S. L., 2004, The influence of urban density and drainage infrastructure on the concentrations and loads of pollutants in small streams: Environmental Management, v. 34, no. 1, p. 112-124.

Herrmann, J., 2012, Chemical and biological benefits in a stormwater wetland in Kalmar, SE Sweden: Limnologica, v. 42, no. 4, p. 299-309.

Kaushal, S. S., and Belt, K. T., 2012, The urban watershed continuum: evolving spatial and temporal dimensions: Urban Ecosystems, v. 15, no. 2, p. 409-435.

Kelly, W. R., 2008, Long-term trends in chloride concentrations in shallow aquifers near chicago: Ground Water, v. 46, no. 5, p. 772-781.

Kim, S. W., Park, J. S., Kim, D., and Oh, J. M., 2014, Runoff characteristics of nonpoint pollutants caused by different land uses and a spatial overlay analysis with spatial distribution of industrial cluster: a case study of the Lake Sihwa watershed: Environmental Earth Sciences, v. 71, no. 1, p. 483-496.

Marsalek, J., Q, R., L, C., and Brownlee, B., 2002, Assesment of Stormwater Impacts on and Urban Stream with a Detention Pond: Water Science and Technology, v. 45, no. 3, p. 255-263.

Meyer, J. L., Paul, M. J., and Taulbee, W. K., 2005, Stream ecosystem function in urbanizing landscapes: Journal of the North American Benthological Society, v. 24 , no. 3, p. 602-612.

Miller, J. D., Kim, H., Kjeldsen, T. R., Packman, J., Grebby, S., and Dearden, R., 2014, Assessing the impact of urbanization on storm runoff in a pen-urban catchment using historical change in impervious cover: Journal of Hydrology, v. 515, p. 5970.

O'Reilly, A. M., Chang, N. B., and Wanielista, M. P., 2012, Cyclic biogeochemical processes and nitrogen fate beneath a subtropical stormwater infiltration basin: Journal of Contaminant Hydrology, v. 133, p. 53-75.

Ren, Y. F., Wang, X. K., Ouyang, Z. Y., Zheng, H., Duan, X. N., and Miao, H., 2008, Stormwater Runoff Quality from Different Surfaces in an Urban Catchment in Beijing, China: Water Environment Research, v. 80, no. 8, p. 719-724.

Sheng, Y., Ying, G., and Sansalone, J., 2008, Differentiation of transport for particulate and dissolved water chemistry load indices in rainfall-runoff from urban source area watersheds: Journal of Hydrology, v. 361, no. 1-2, p. 144-158.

Shertzer, R. H., Hall, D. W., Steffy, S. A., and Kime, R. A., 1998, Relationships between land uses and rainwater quality in a southcentral Pennsylvania watershed: Journal of the American Water Resources Association, v. 34, no. 1, p. 13-26. 
Stiff, B. J., 2000, Surficial Deposits of Illinois: Department of Natural ResourcesIllinois State Geological Survey ISGS OFS 2000-2007.

Tixier, G., Rochfort, Q., Grapentine, L., Marsalek, J., and Lafont, M., 2012, Spatial and seasonal toxicity in a stormwater management facility: Evidence obtained by adapting an integrated sediment quality assessment approach: Water Research, v. 46, no. 20, p. 6671-6682.

Tribe, A., 1992, Automated recognition of valley lines and drainage networks from grid digital elevation models- a review and a new method: Journal of Hydrology, v. 139 , no. $1-4$, p. 263-293.

U.S. Environmental Protection Agency (1999) Preliminary Data Summary of Urban Storm Water Best Management Practices. U.S. Environmental Protection Agency http://water.epa.gov/scitech/wastetech/guide/stormwater/ Updated: March 2012, Accessed December 2013

U.S Census Bureau (2010) "State \& County Quick Facts" http://quickfacts.census.gov/qfd/states/17/1706613.html_Updated: June 2013. Accessed: December 2013

Walsh, C. J., Fletcher, T. D., and Burns, M. J., 2012, Urban Stormwater Runoff: A New Class of Environmental Flow Problem: Plos One, v. 7, no. 9.

Walsh, C. J., Fletcher, T. D., and Ladson, A. R., 2005a, Stream restoration in urban catchments through redesigning stormwater systems: looking to the catchment to save the stream: Journal of the North American Benthological Society, v. 24, no. 3, p. 690-705.

Walsh, C. J., Roy, A. H., Feminella, J. W., Cottingham, P. D., Groffman, P. M., and Morgan, R. P., 2005b, The urban stream syndrome: current knowledge and the search for a cure: Journal of the North American Benthological Society, v. 24, no. 3, p. 706-723.

Wang, X. J., Zhang, J. Y., Cai, H. J., ElMahdi, A., Ali, M., He, R. M., and Guan, T. S., 2011, Spatio-temporal characteristics and driving forces of annual runoff changes in northwest of China - taking the example of Yulin city: Urban Water Journal, v. 8, no. 5, p. 309-323.

Weibel, C. P., and Nelson, R. S., 2009, Geology of the Mackinaw River Watershed, McLean, Woodford, and Tazewll Counties, Illinois: Champaign, IL, Institute of Natural Resource SustainabilityIllinois State Geological Survey

Welty, C., 2009, The Water Environment of Cities, Baltimore, MD, Springer Science + Business LLC. 
APPENDIX A

STORM SEWERSHED MAPS, LOCATIONS

AND DESCRIPTONS 


\section{Parking Lot at Airport Street}

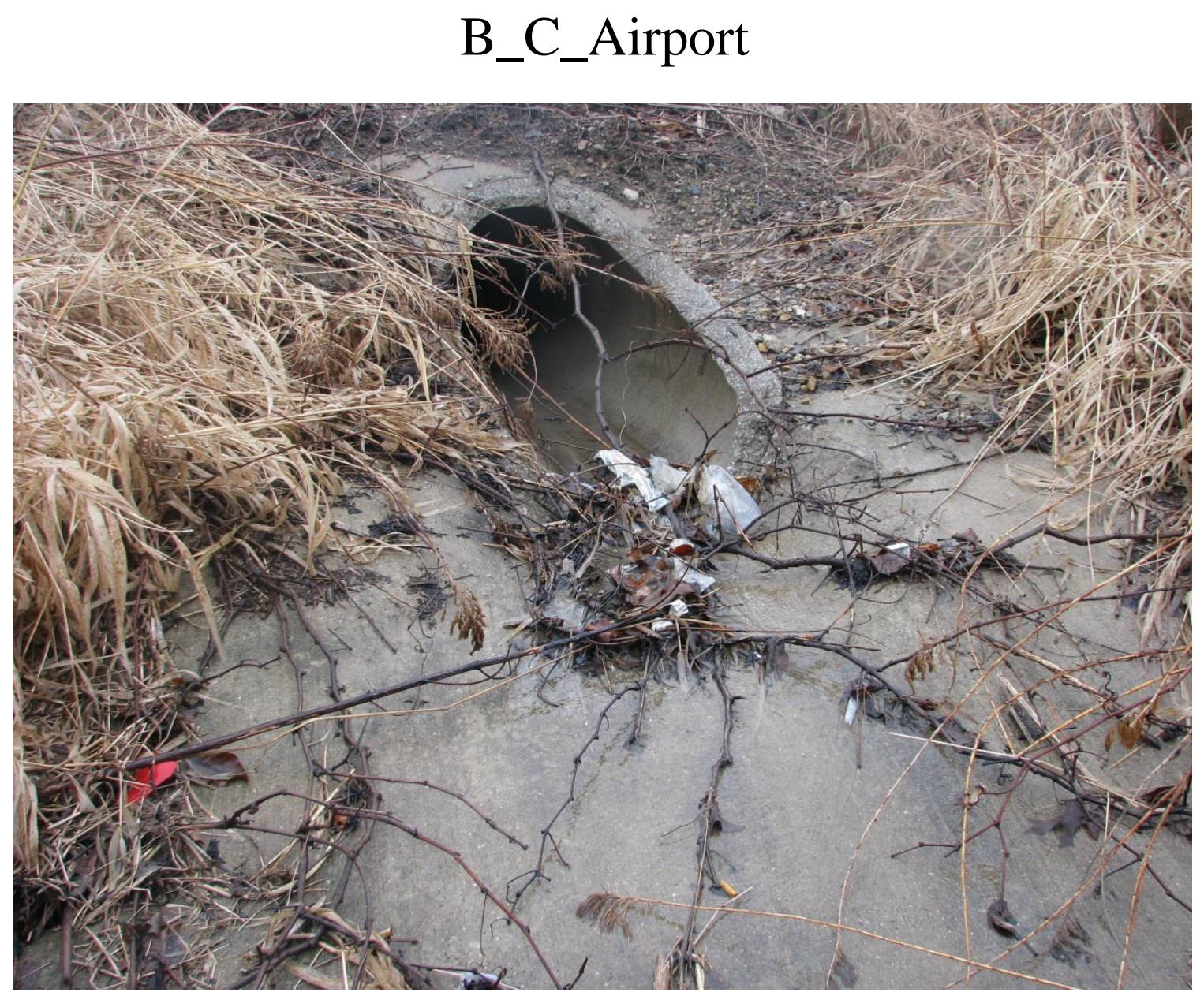

This is a private sewer system. It drains a parking lot on the corner or General Electric Road and Airport Road. It has a 12 inch diameter pipe at its outlet. The outlet is located on the north side of the stream. There are broken slabs of concrete in front of the outlet 


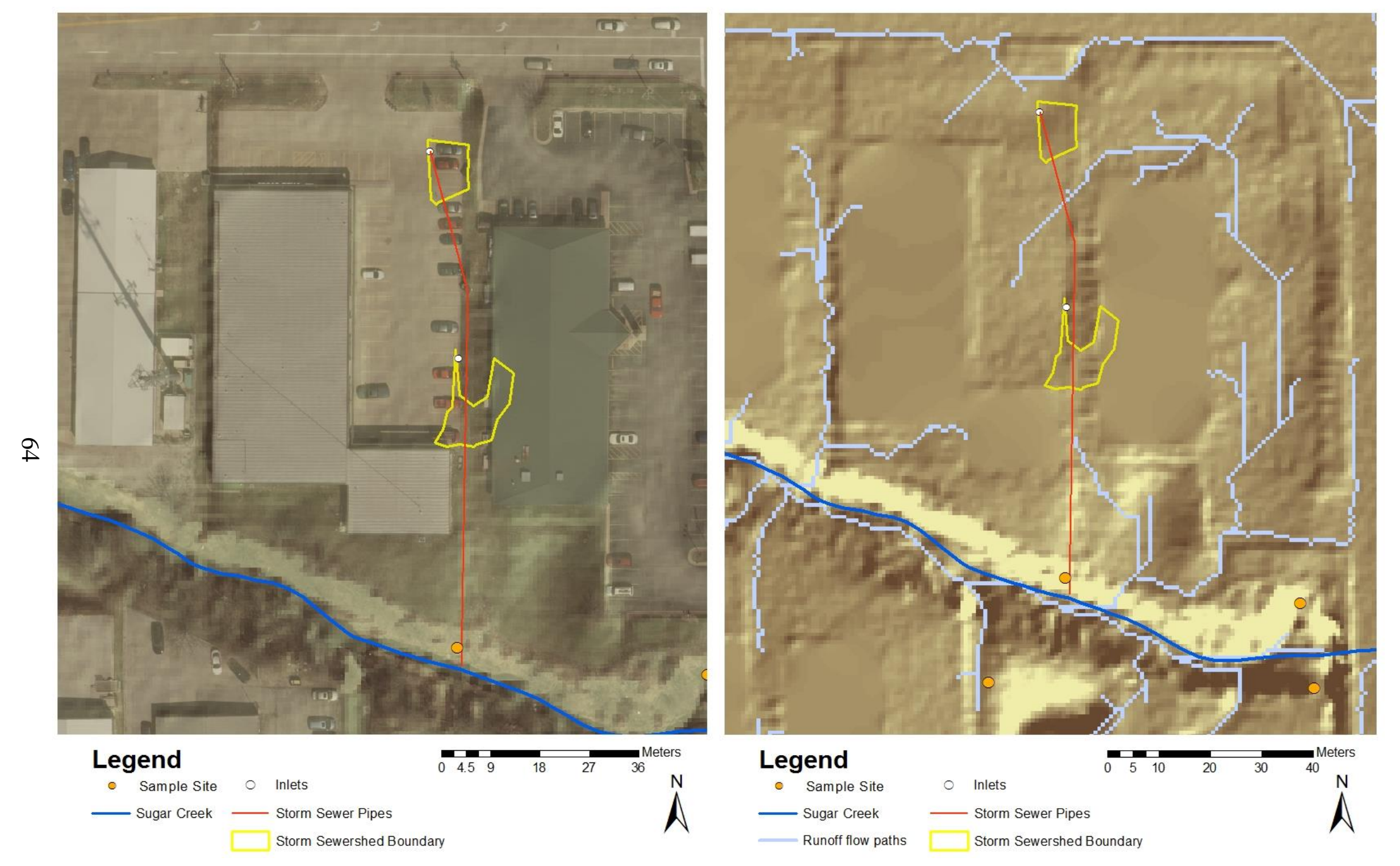




\section{Commercial Drainage on General Electric Street}

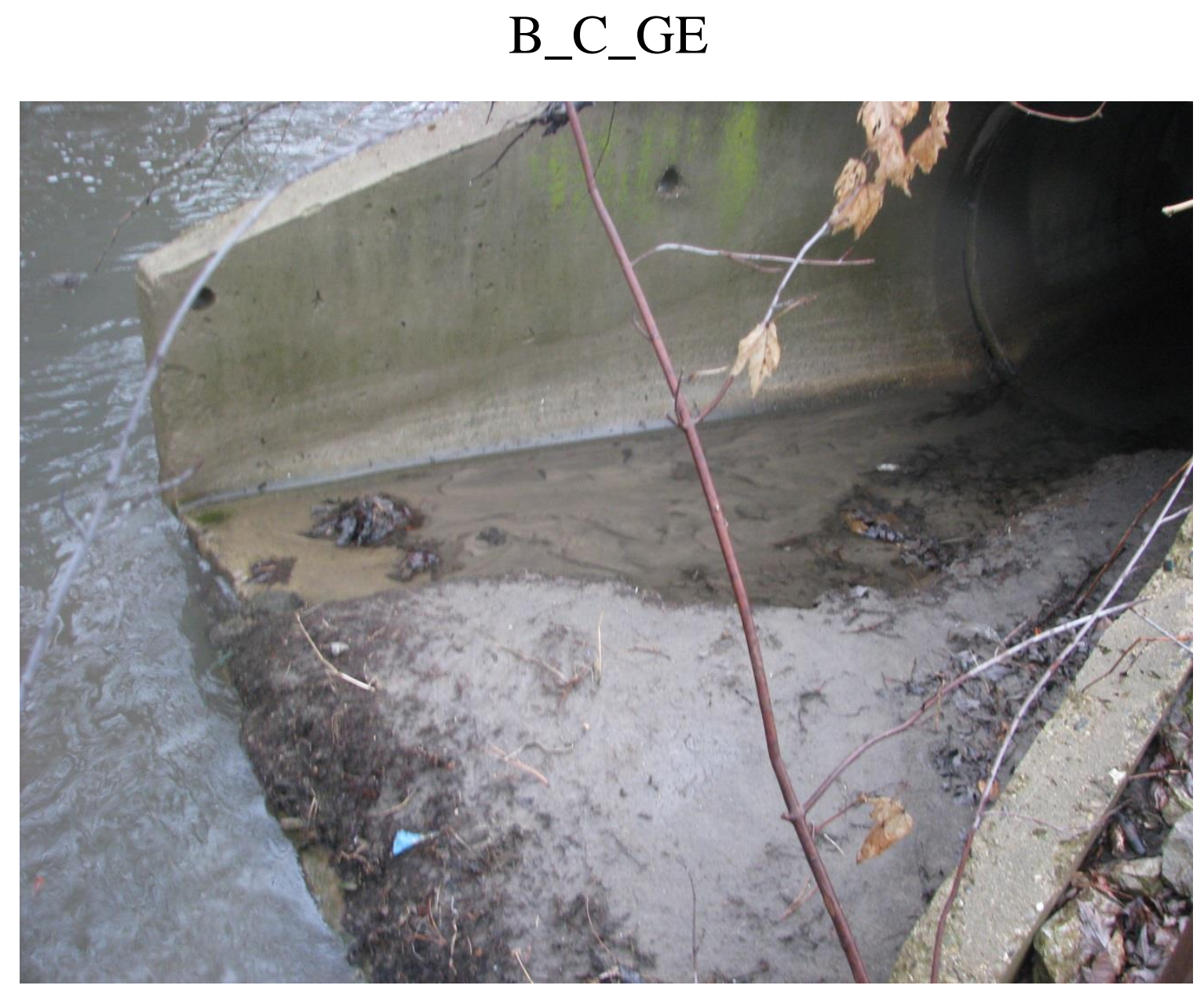

This is a public sewer system. It drains a commercial lot south of General Electric Road. The outlet has a 48 inch diameter. I access this location from Hedgewood Park on the north end of Sugar Creek. This is a private park that I accessed with permission from the homeowner's association. I crossed Sugar Creek from the park and B_C_GE is located upstream. I walked upstream passed two sets of riprap. It is the most downstream outlet in a set of two. The outlet's tongue has a large amount of sediment accumulated. 

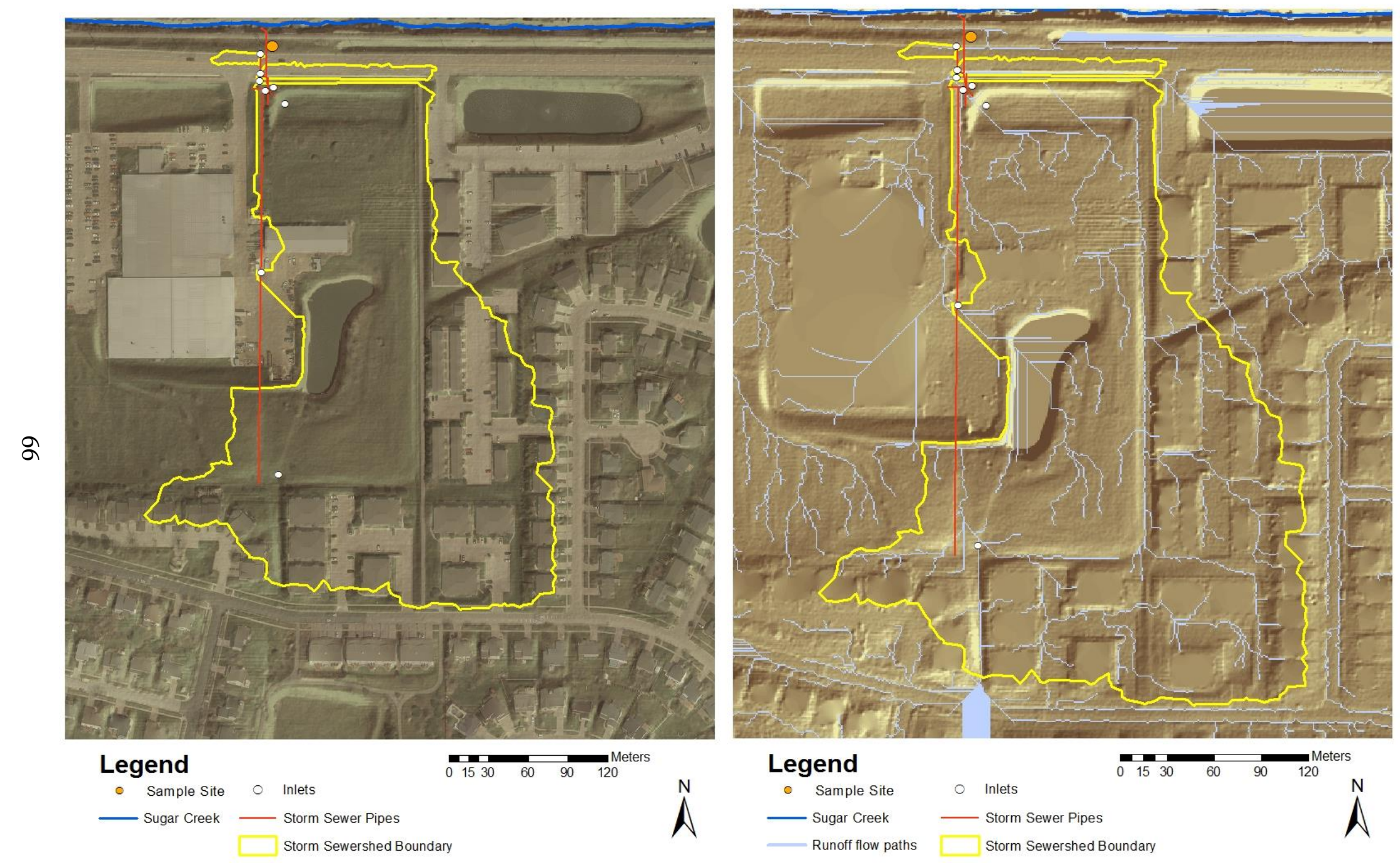


\section{Commercial Drainage on Vernon Street}

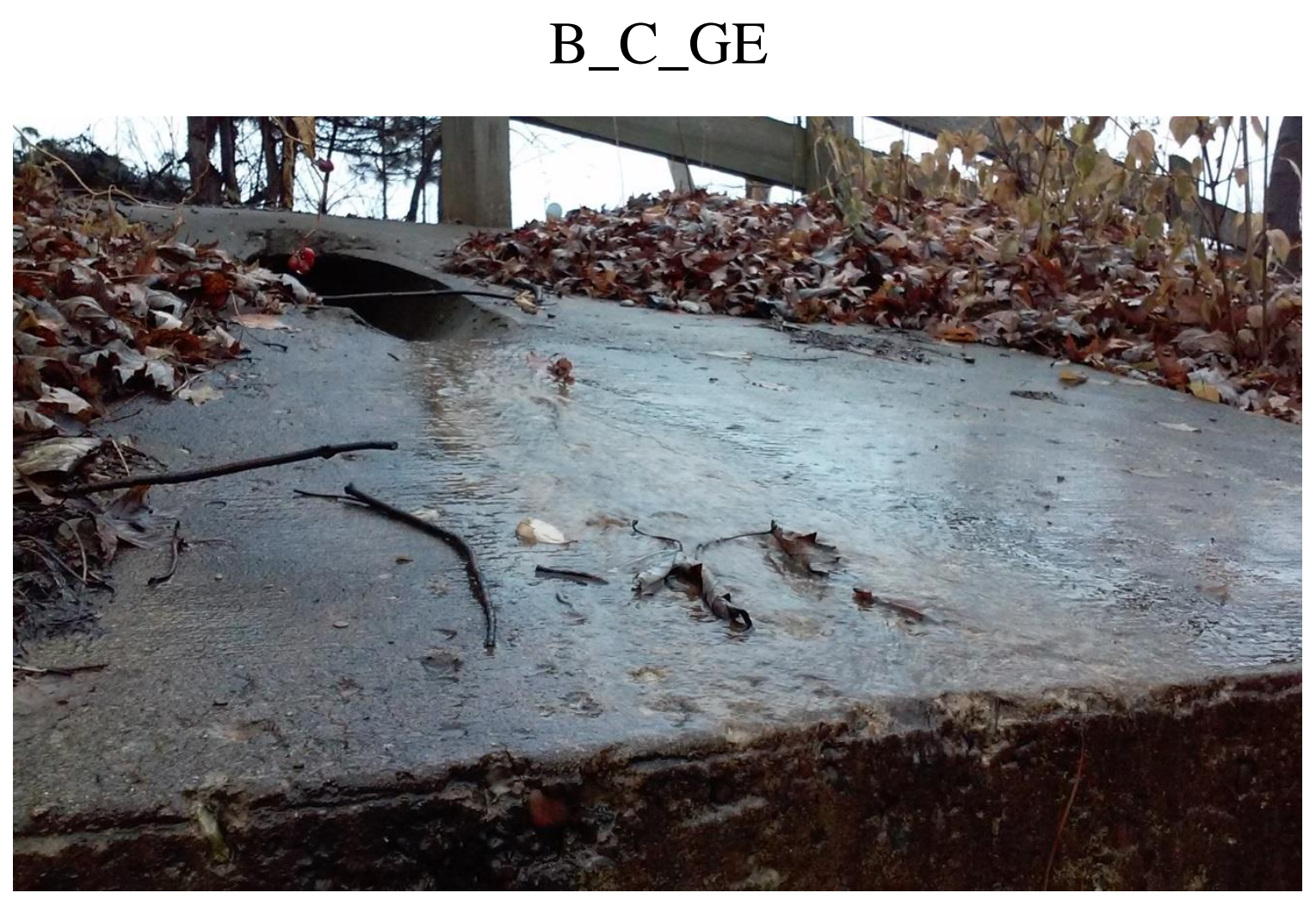

Public sewer system, draining commercial parking lots south of Vernon Road. It has an 18 inch diameter outlet pipe. To access this site I parked at Jason's Deli on Vernon Road. There is access to the constitution trail from there. B_C_Vernon is downstream of the access point. The outlet is located under a fence there is a garbage can immediately before it. The outlet drains to a small gully and there is about a 2 foot drop below the tongue of the outlet. 

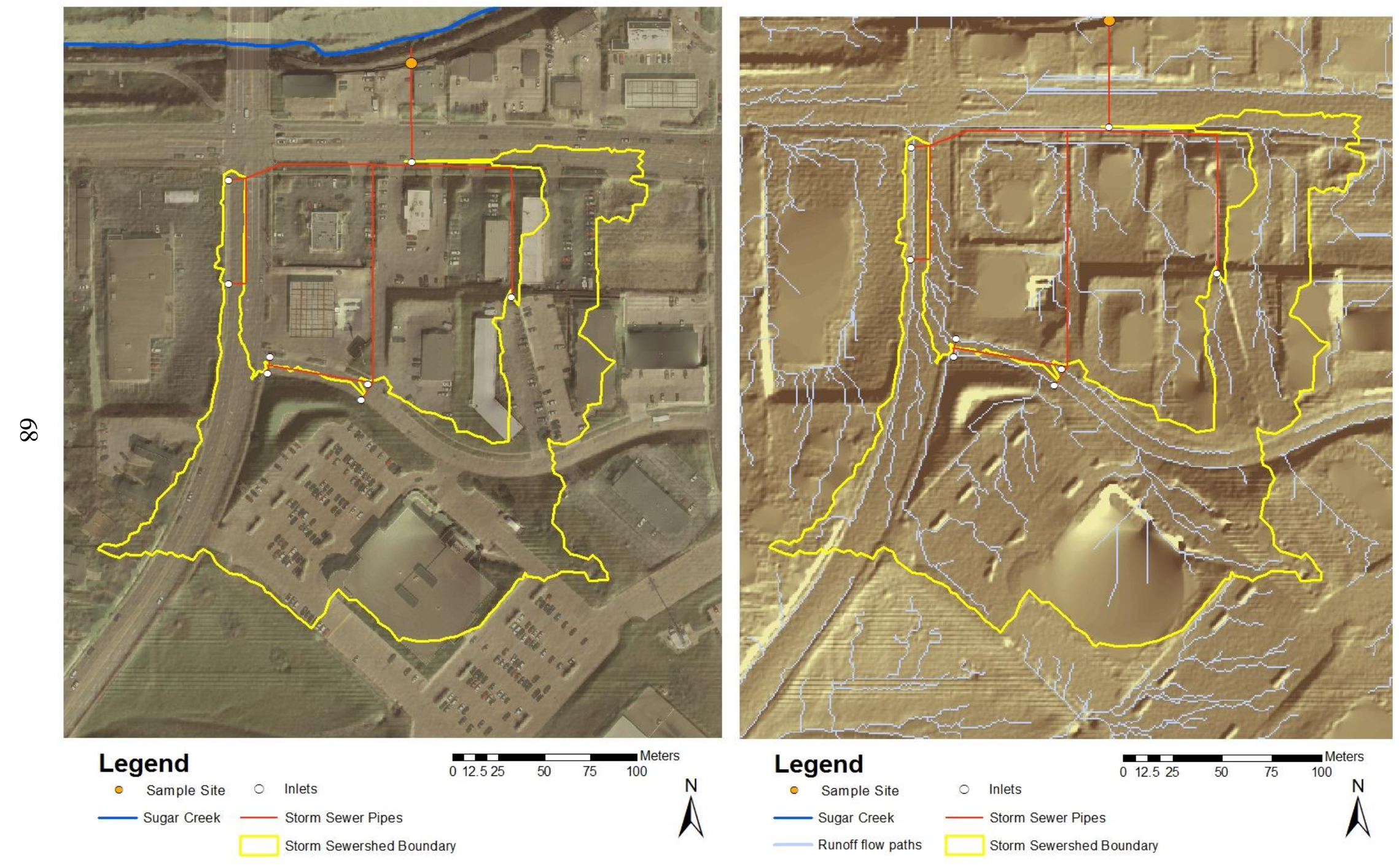


\section{Residential and Park Drainage at Airport Street}

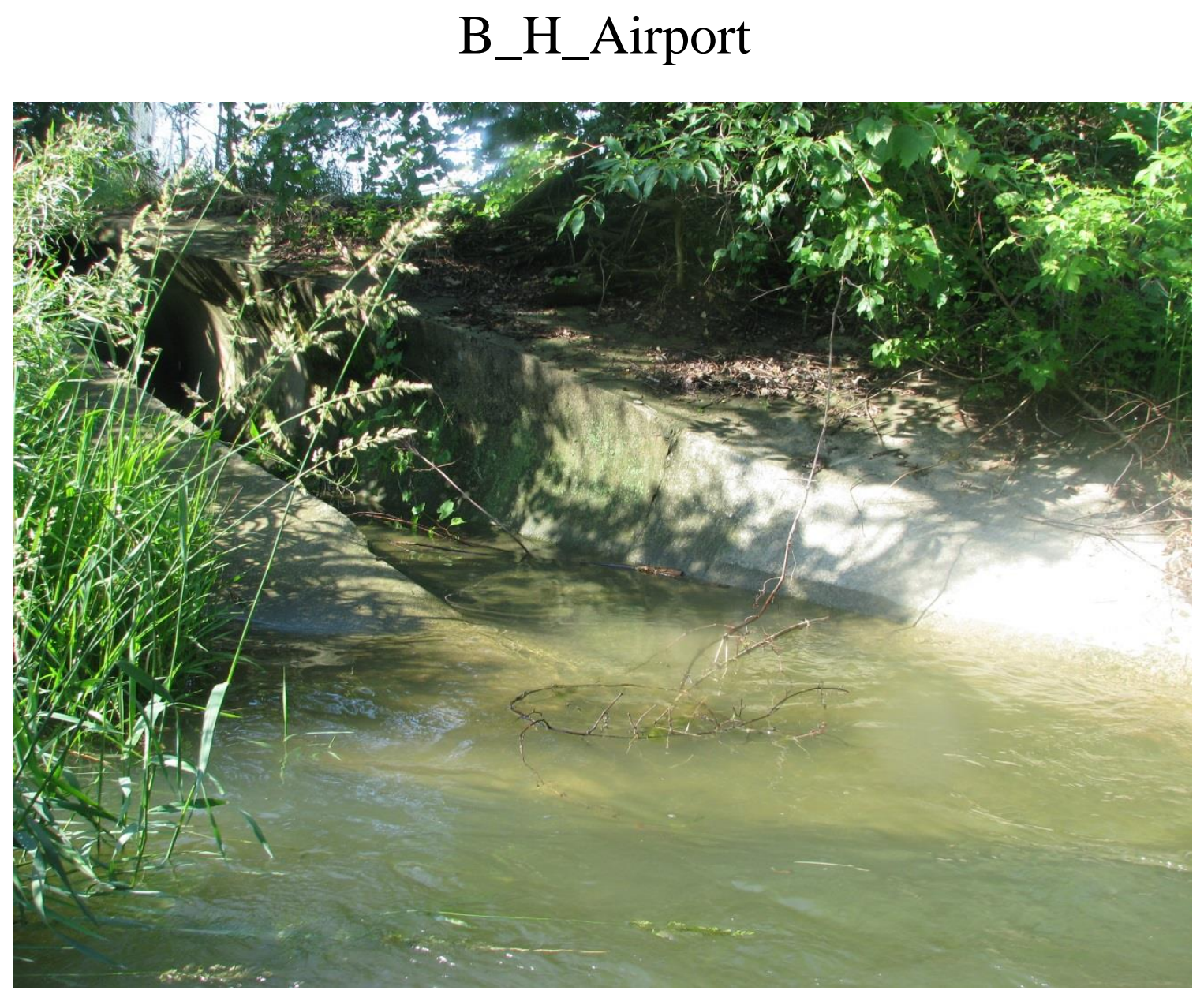

This is a public sewer system draining a residential area south of General Electric Road. It has a 54 diameter outlet pipe. I accessed the site from the corner of General Electric Road and Airport Rd. This is the furthest upstream site from this access location. When walking upstream from B_C_Airport this site is on the left side. It has a very long tongue which is usually raised only a few inches from the stream. This site has tendency to flood during large storm events as shown in the picture. 

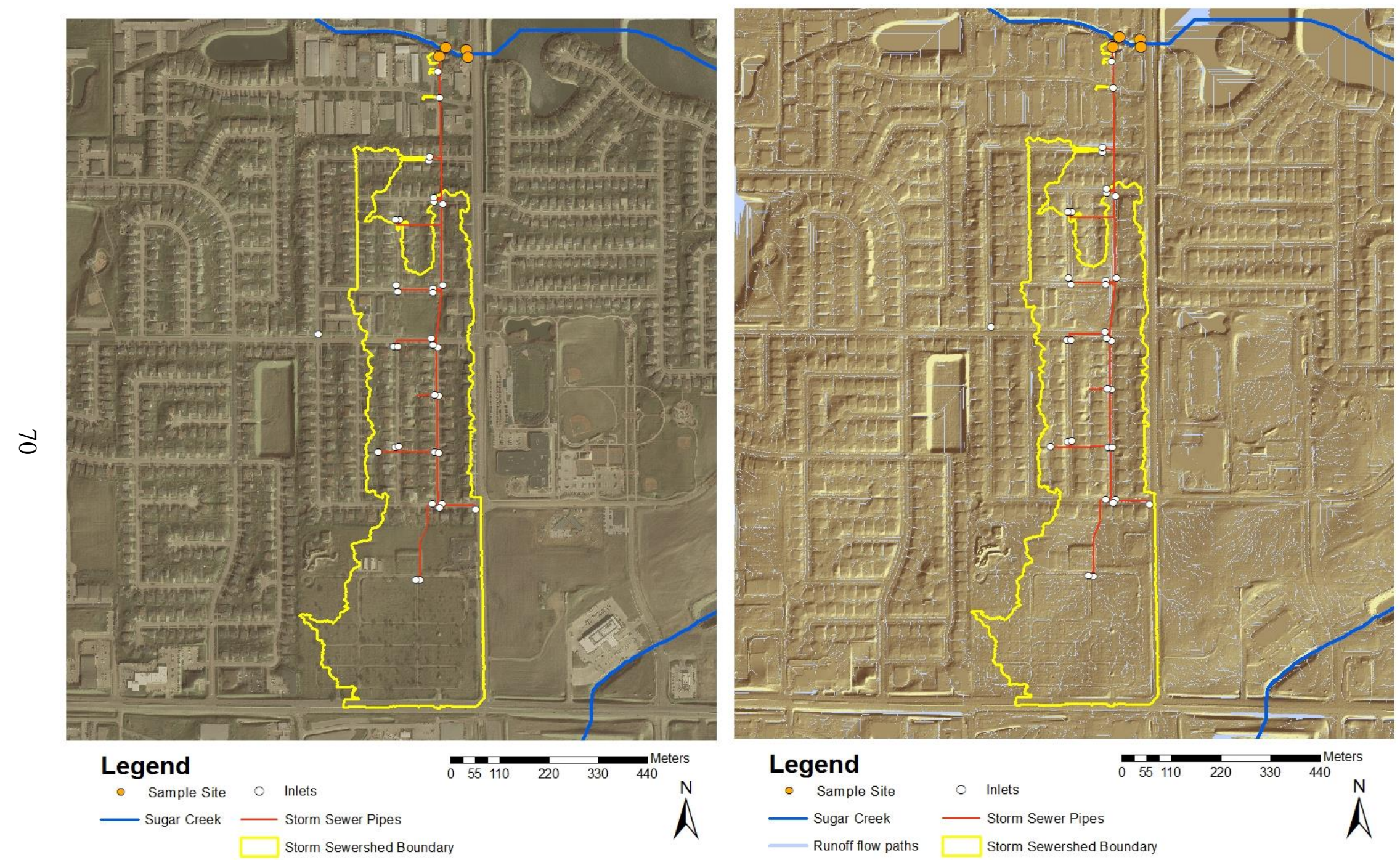


\section{Residential Drainage at White Oak Park}

\section{B_H_Cott}

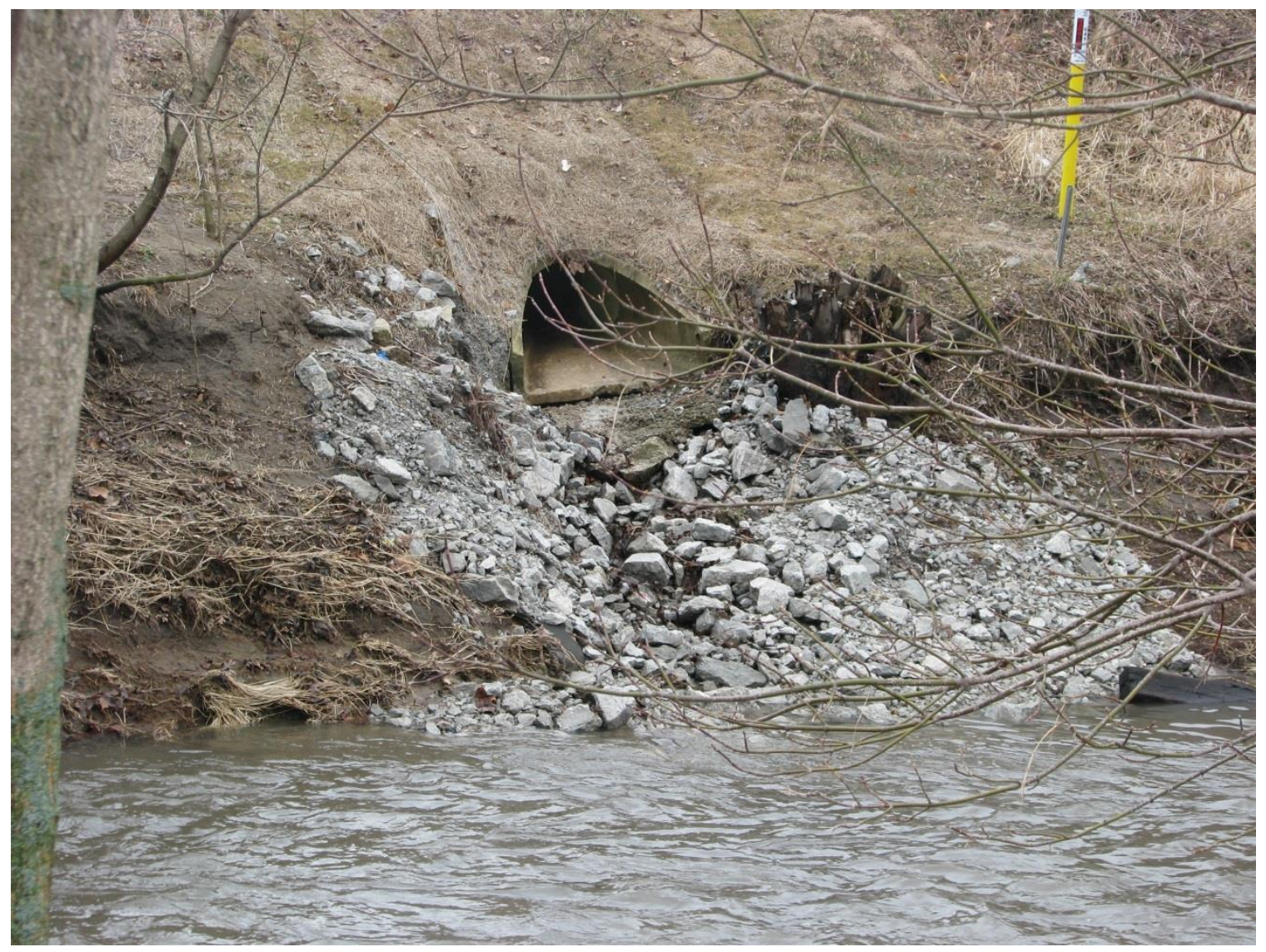

This is a public sewer draining a residential area south of Sugar Creek and east of White Oak Park. I accessed the site from the White Oak Park parking lot on Cottage Street. The outlet is across a foot bridge and slightly to the north. The outlet pipe is 24 inches in diameter. There is a gap between the pipe and the tongue, during low flow conditions water will not travel over tongue. 


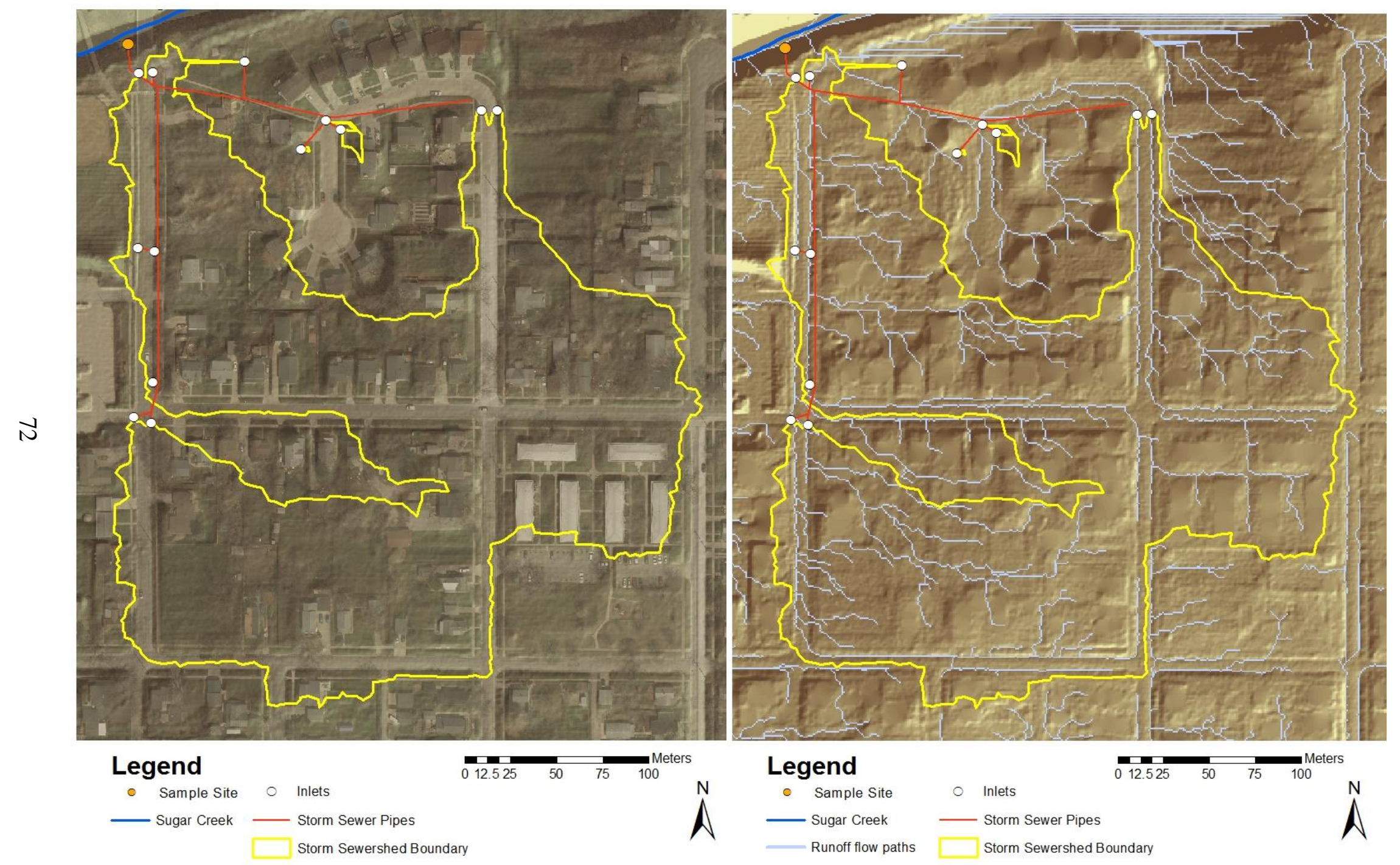




\section{Apartment Complex Drainage at Ewing Park}

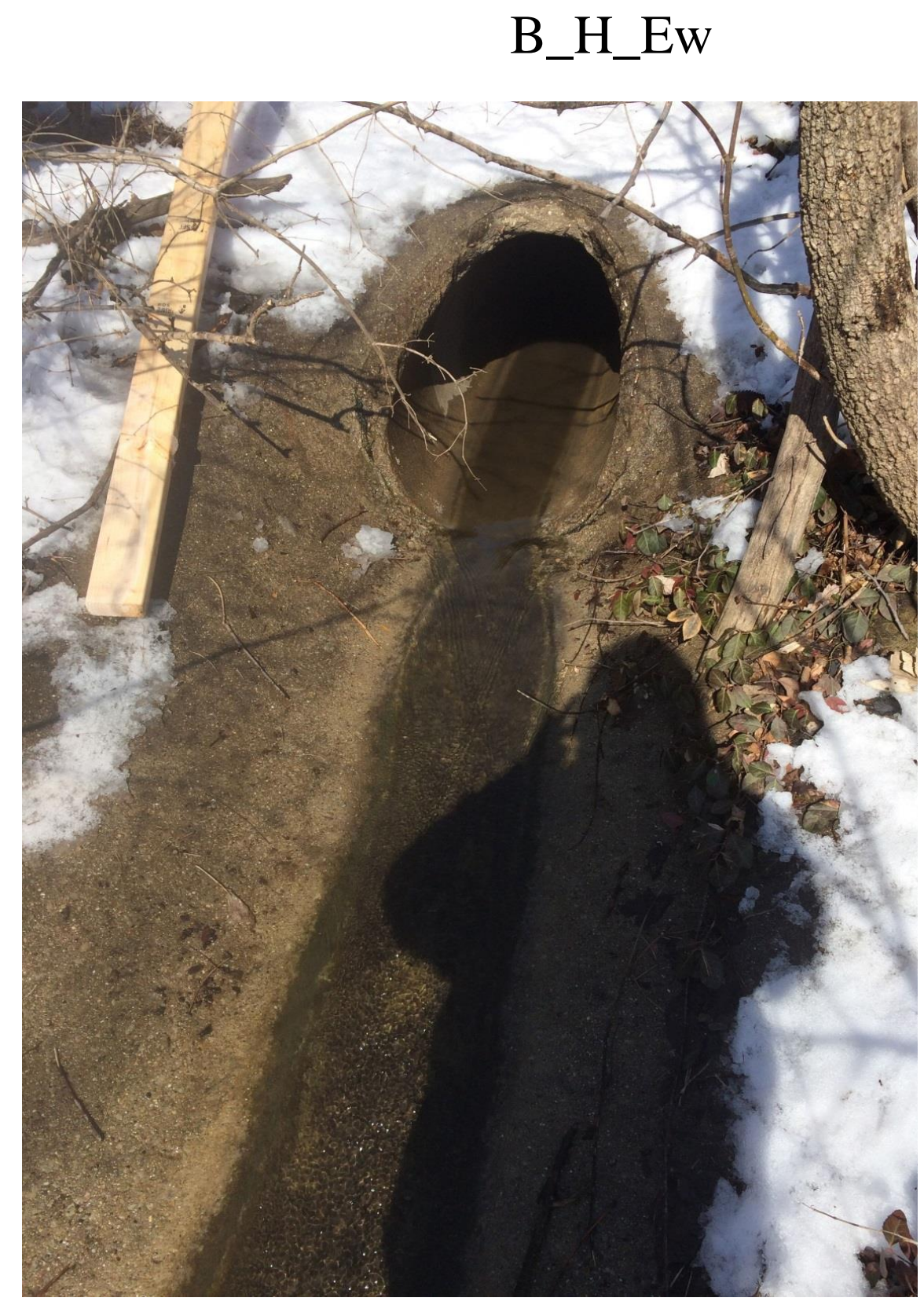

This is a public sewer draining a residential area north of Sugar Creek and Ewing Park. The pipe diameter throughout the system is 12 inches. I accessed the site from Ewing Park II entrance from Ethel Parkway. From the end of the road the site is upstream, and on the northern bank. It is the only storm sewer outlet in the area with a tongue. Across the stream from the site is another storm sewer pipe that extends several feet over the stream. 


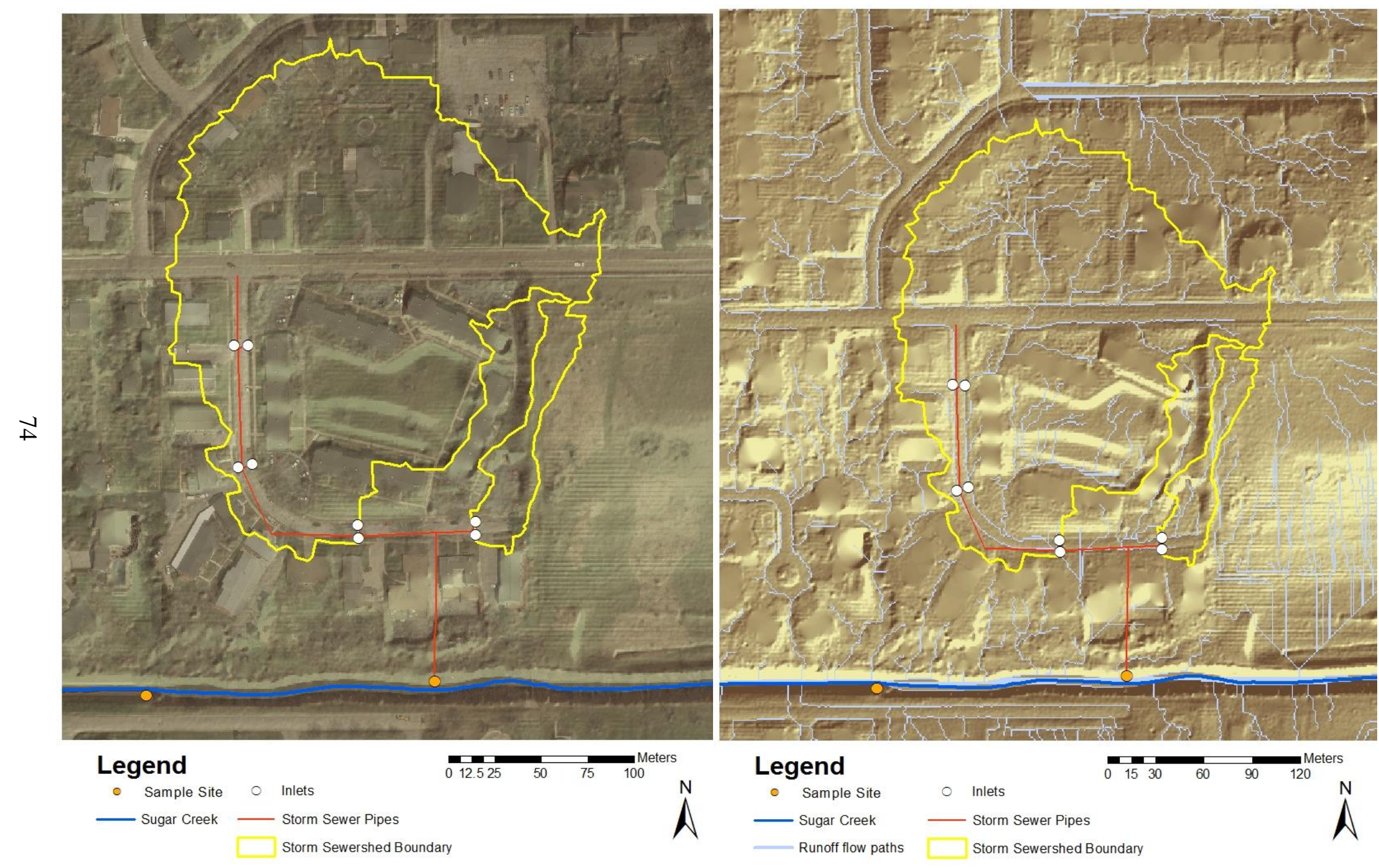




\section{Hedgewood Park}

\section{B_H_GE}

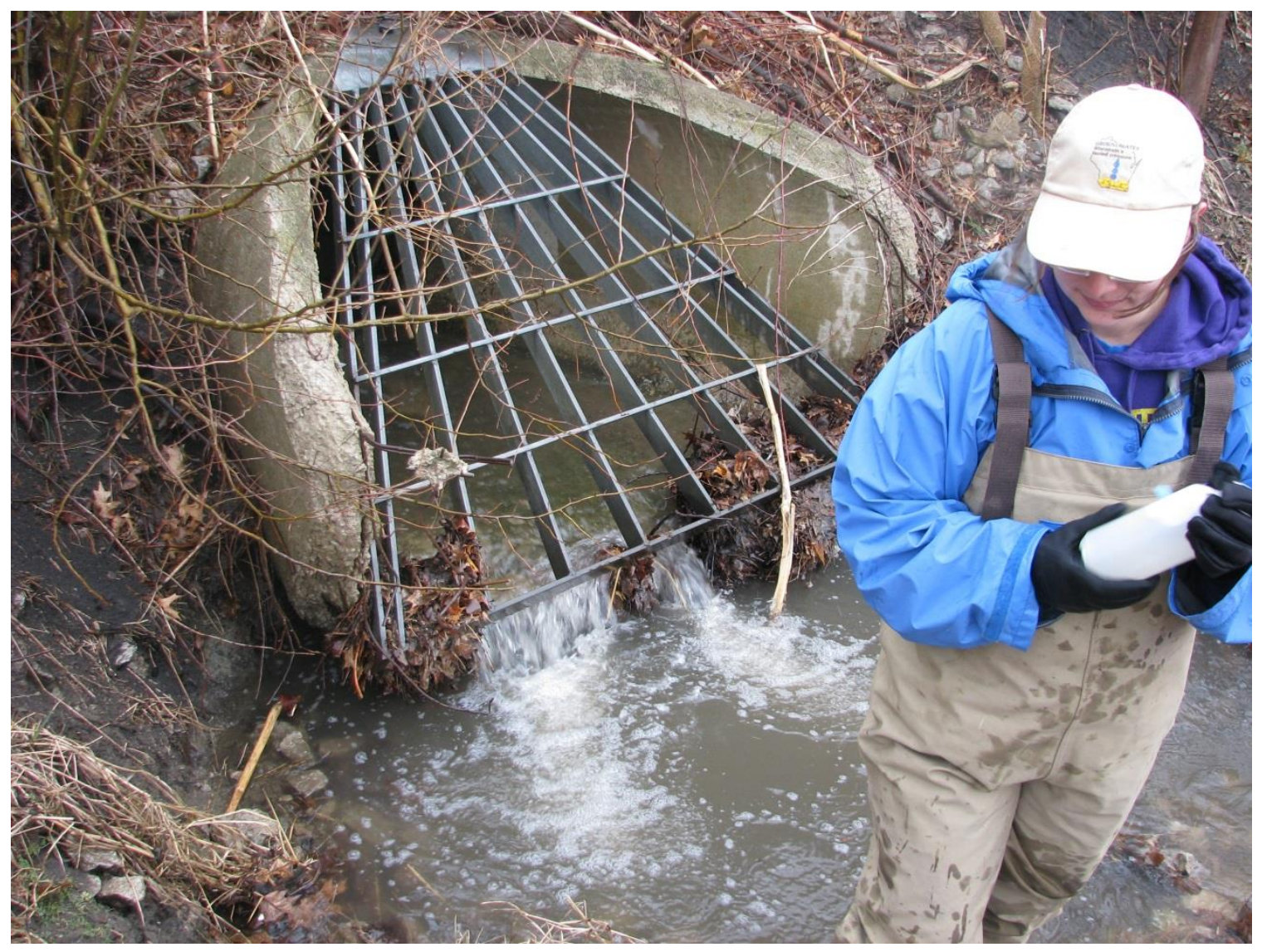

This is a public storm sewer system draining a residential area north of Sugar Creek. The pipe diameter at the outlet is 42 inches with a grate covering it. The grate is often clogged leaf litter. I accessed this site as well as B_C_GE and B_L_GE from Hedgewood Park. It is a private park run by the Hedgewood Park Homeowner's Association. I gained permission from the HOA. This site is located on the east side of the park near the tennis courts. 


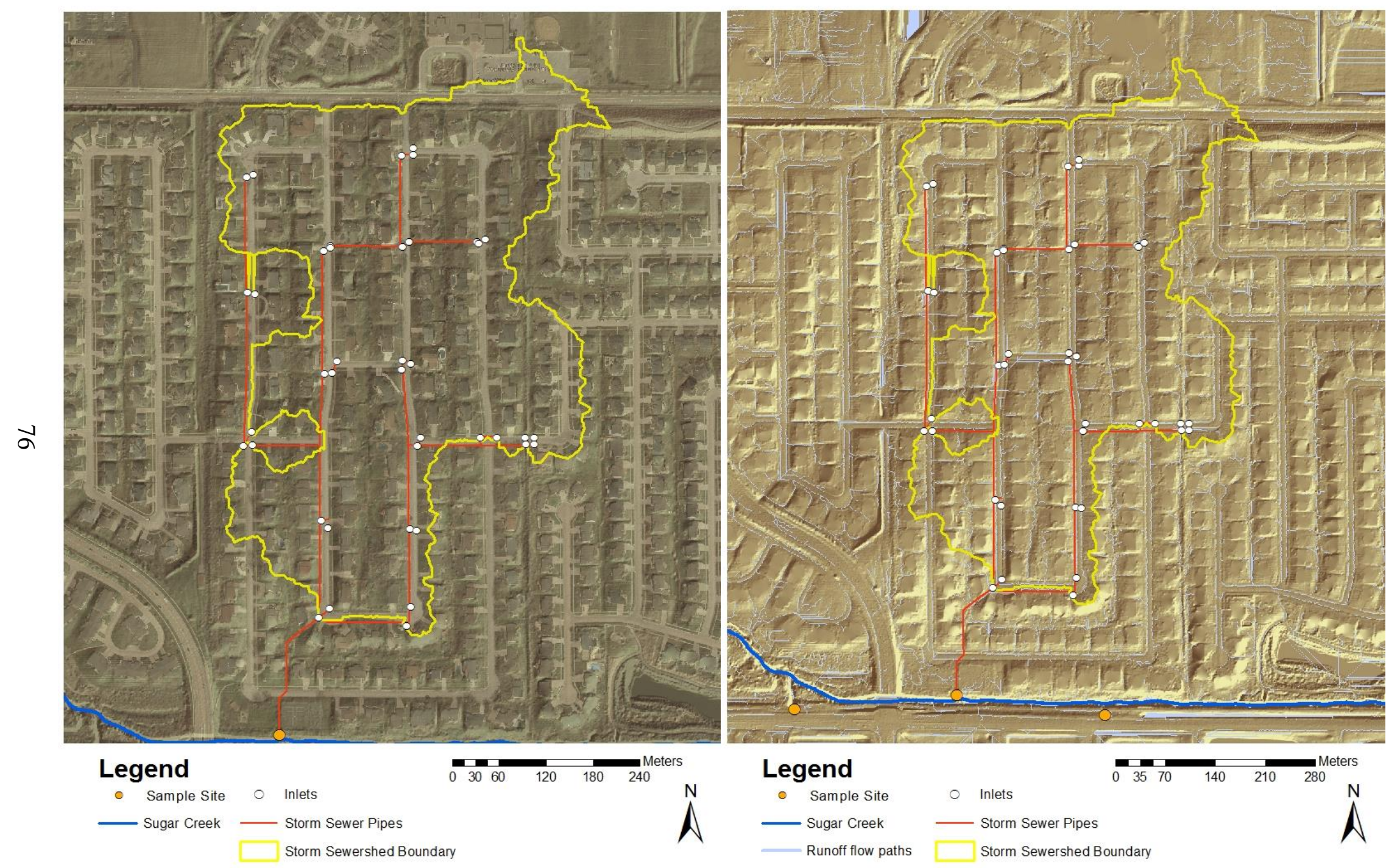




\section{Residential Drainage at G.E. and Airport}

\section{B_H_GEAir}

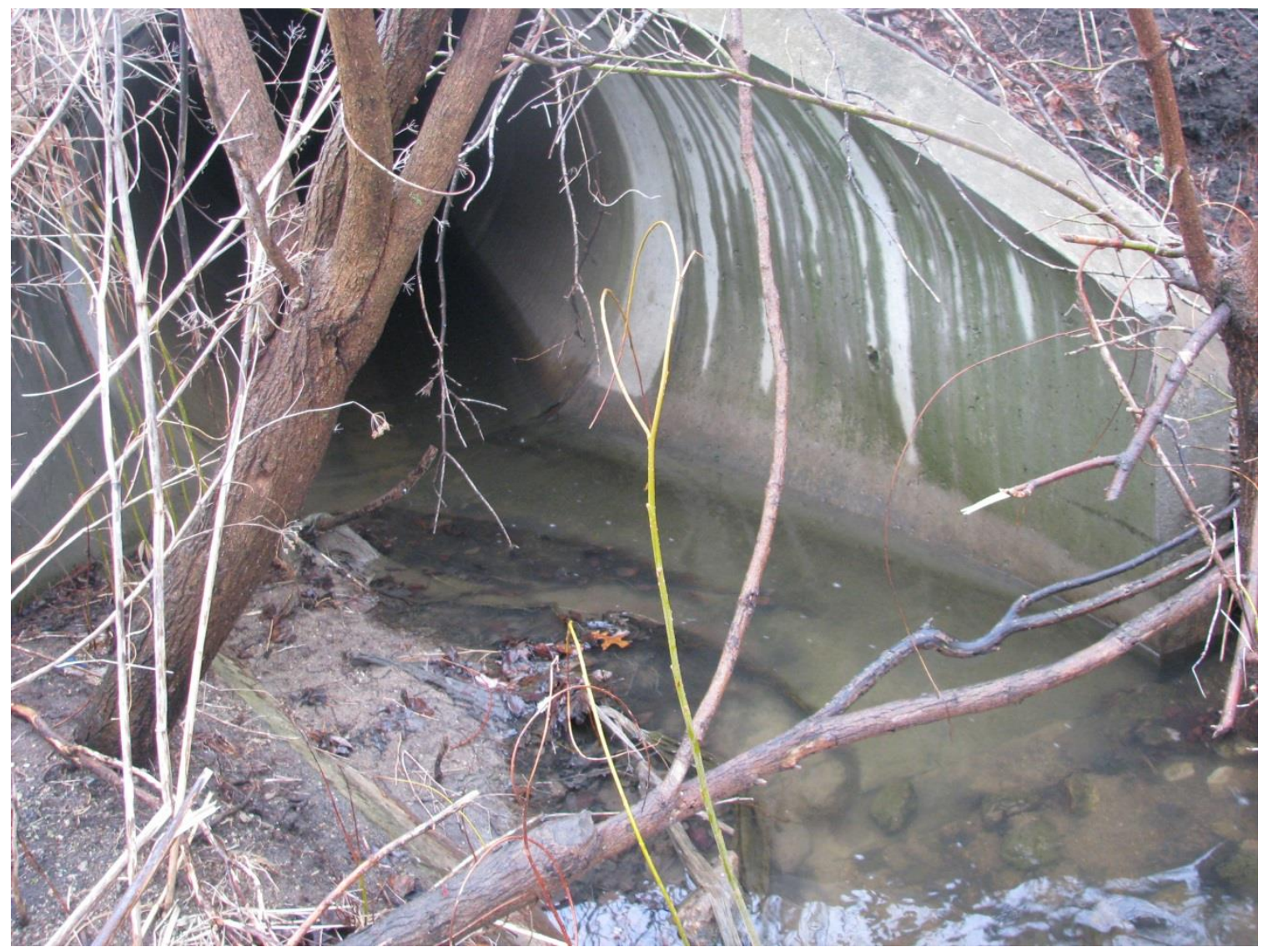

This a public storm sewer system draining a residential systems north of Sugar Creek.

The outlet pipe is 60 inches. I accessed this pipe from the corner of General Electric Road and Airport Road. It is located on the north side of the stream near a bridge over Airport Road. This site drains a large detention pond and usually has at least six inches of water flowing out. 


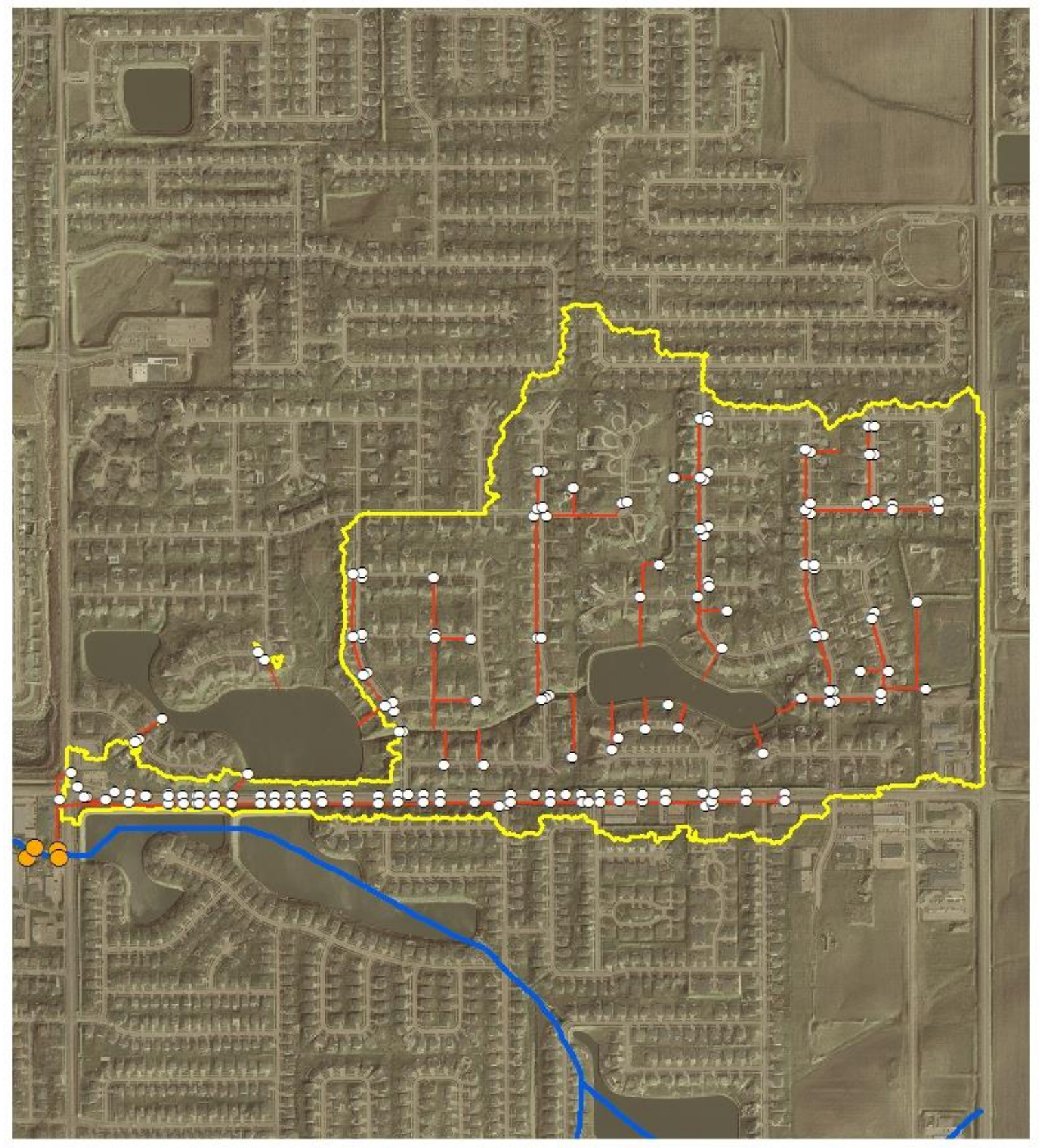

\section{Legend}
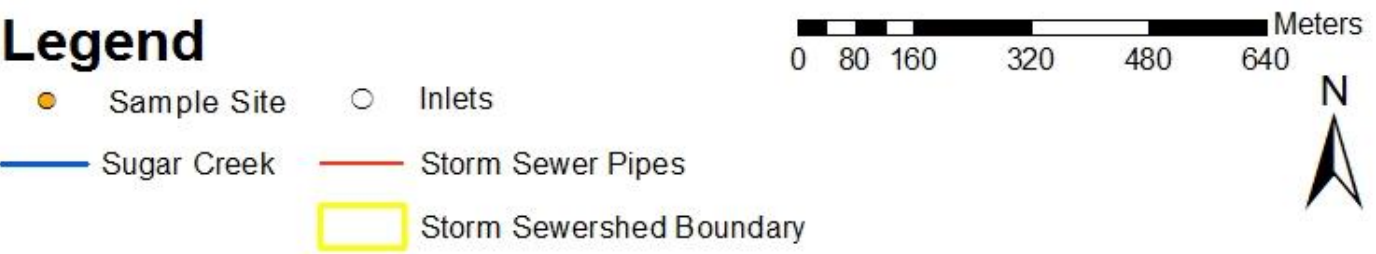


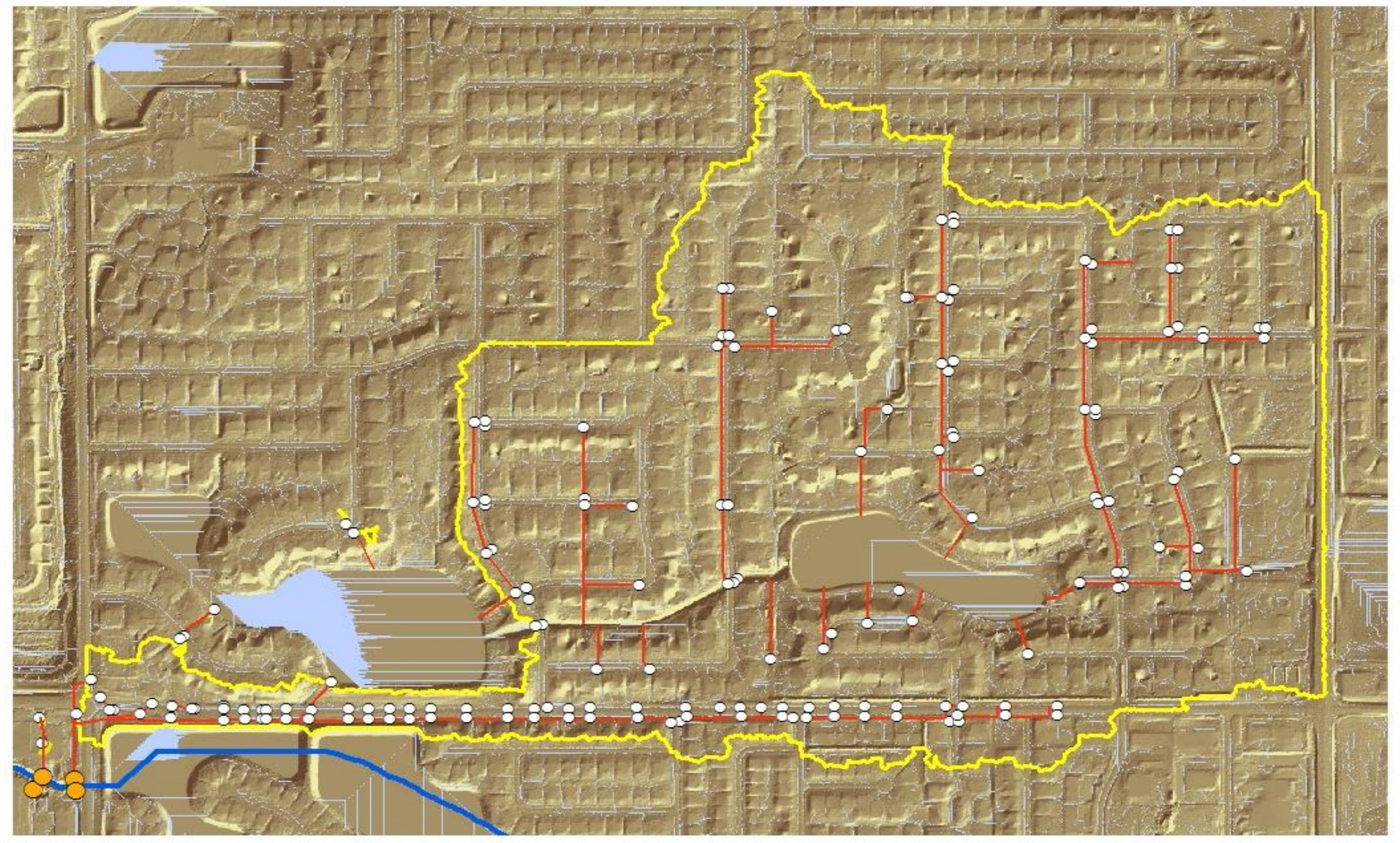

\section{Legend}

- Sample Site

- Sugar Creek

__ Runoff flow paths
- Inlets

_ Storm Sewer Pipes

Storm Sewershed Boundary
$0 \quad 60 \quad 120$

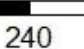

Meters

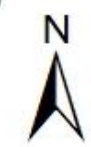




\section{Residential Drainage at Jersey Street}

\section{B_H_Jersey}

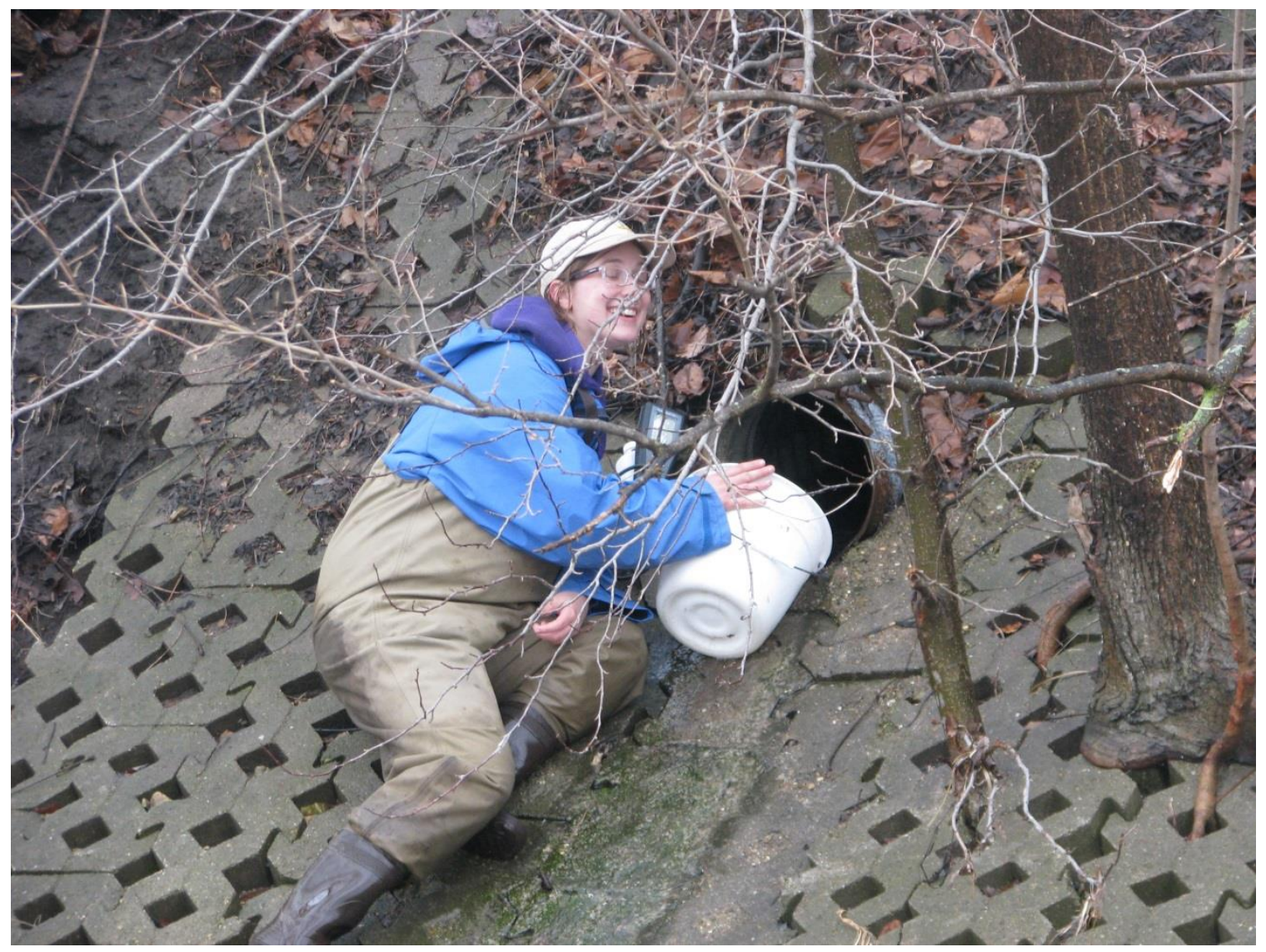

This is a public sewer system. The outlet pipe has a 12 inch diameter draining a road in a residential area south of Sugar Creek off of Jersey St. I accessed this site from Jersey Street on the north side of Ewing Park. This pipe is about $100 \mathrm{ft}$ downstream from the bridge. There is no tongue for this storm sewer. The pipe is rusted and ends before the concrete bank, the water will often drain below some of the concrete and in low flow conditions is difficult to sample. 

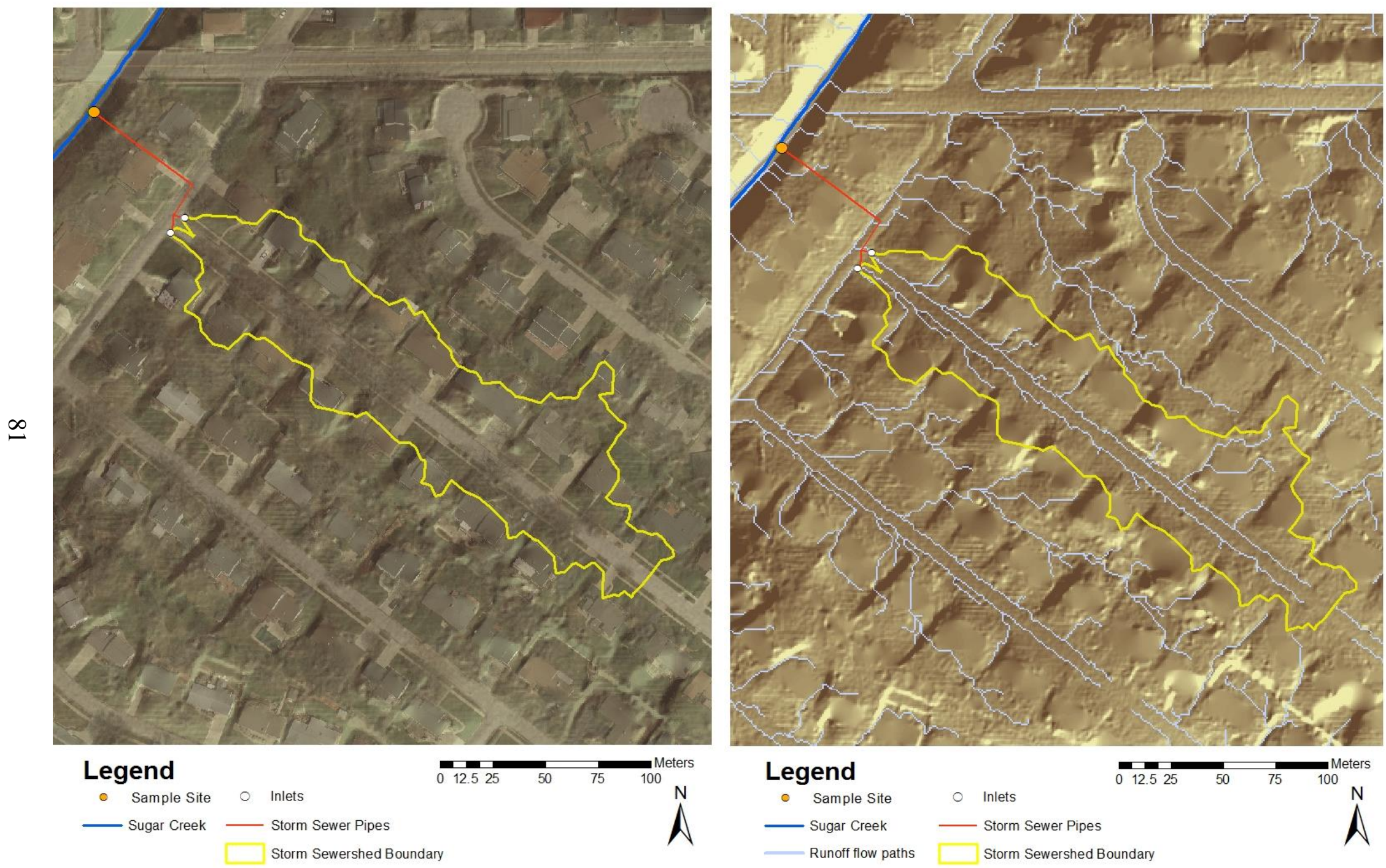


\section{Residential Drainage at Rowe St}

\section{B_H_Rowe}

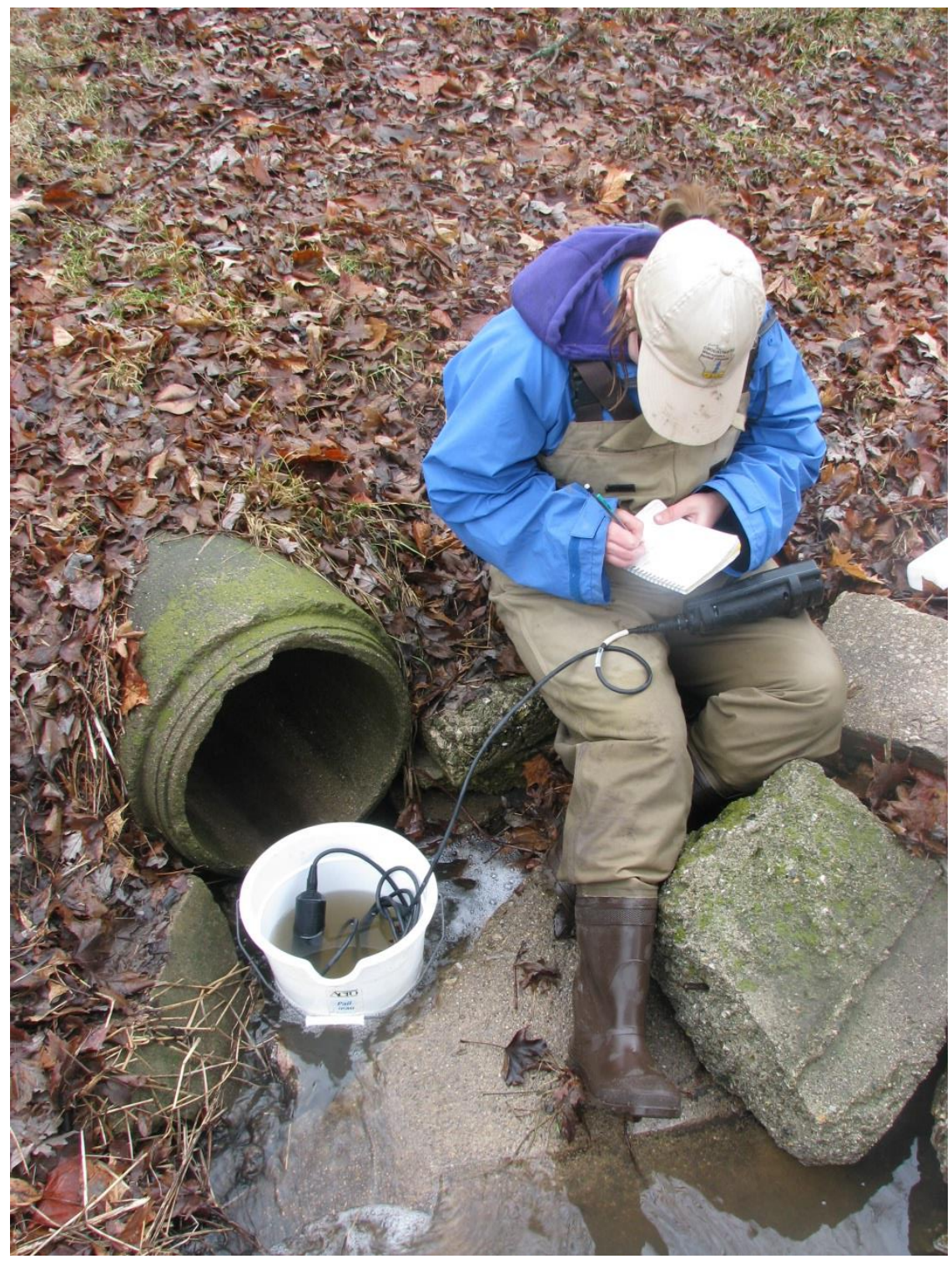

This is a public storm sewer system. The outlet pipe is 15 inch pipe. It drains a residential area south of a tributary of Sugar Creek off of Rowe Street. I accessed this site from Rowe Street, just before Delmar Lane. The pipe is on the south side of the tributary, it has no tongue and sticks out into a small gully. 

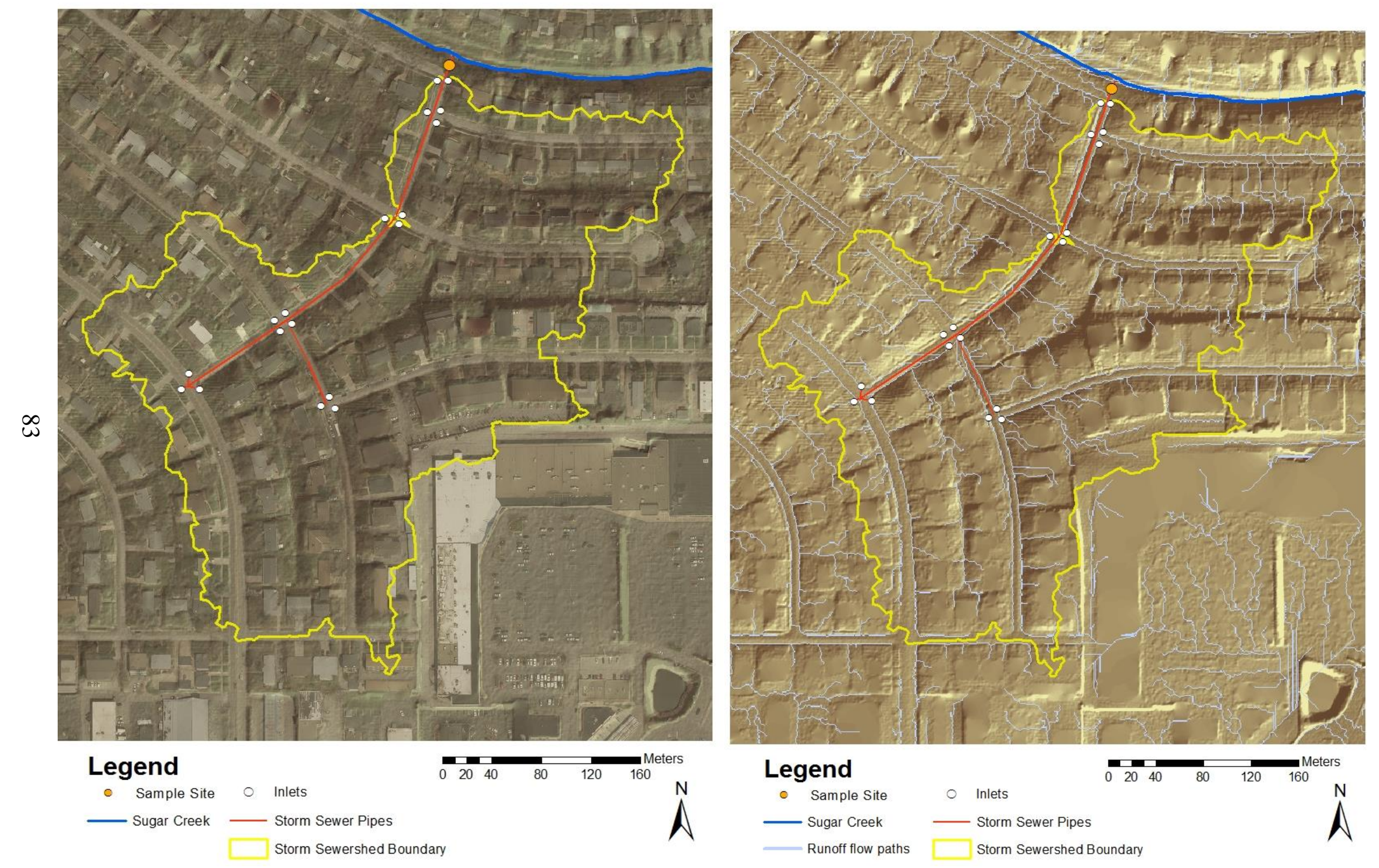

\section{Legend}

$\stackrel{N}{N}$

$-\quad$ Sample Site
- Sugar Creek

Runoff flow paths

$\circ$ Inlets

_ Storm Sewer Pipes

\begin{tabular}{llllll}
\hline 0 & 20 & 40 & 80 & 120 & 160
\end{tabular}

Storm Sewershed Boundary 


\section{Residential Drainage at Tipton Park}

\section{B_H_Tipton}

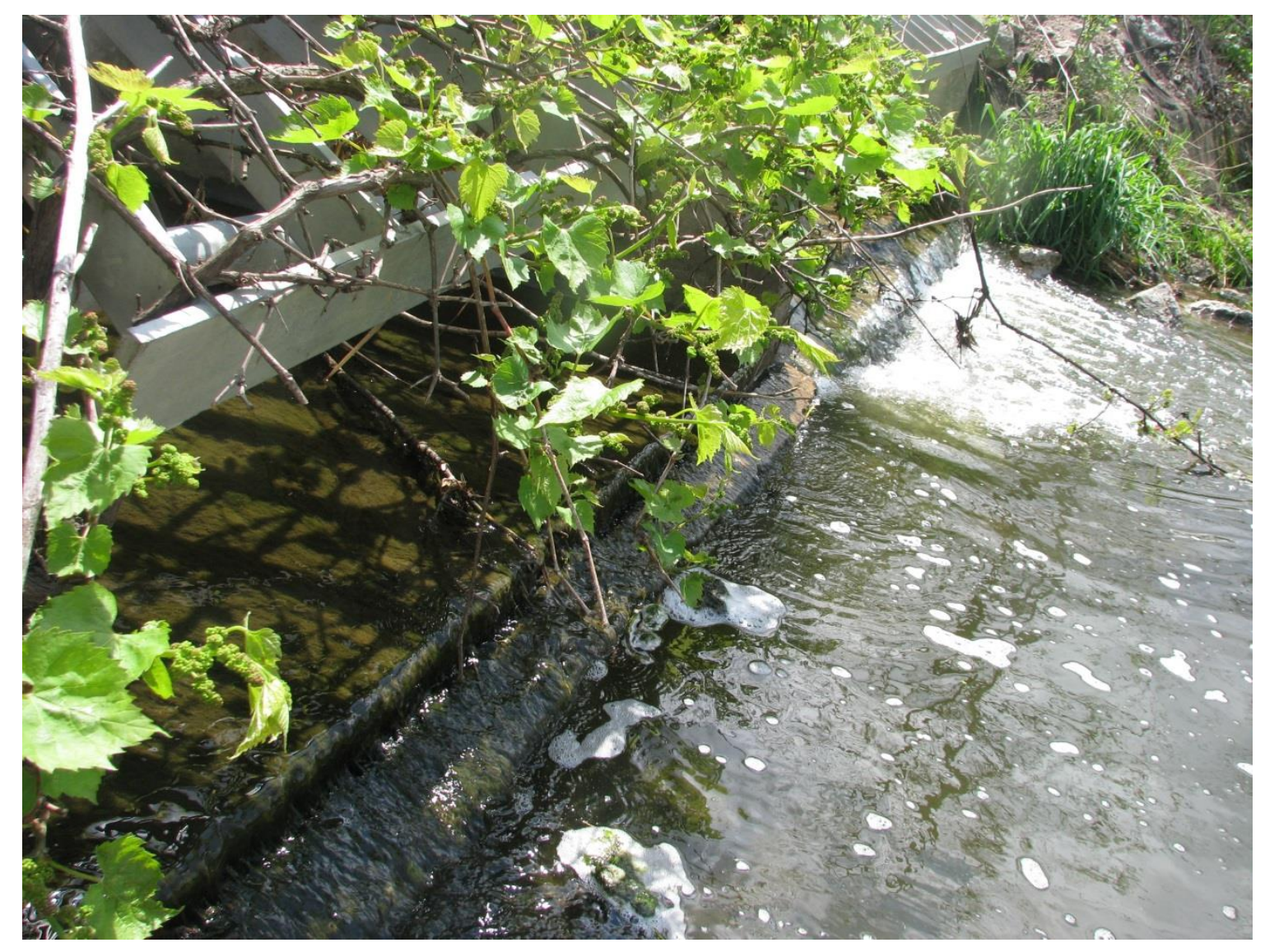

This is a public storm sewer system. There are two outlet pipes each 72 inches in diameter exiting a retention pond from Tipton Park. I accessed this site from Tipton Park, the outlet is past the port-a-potty, and there is a large gully just off the trail. I sampled from the southside outlet pipe. 

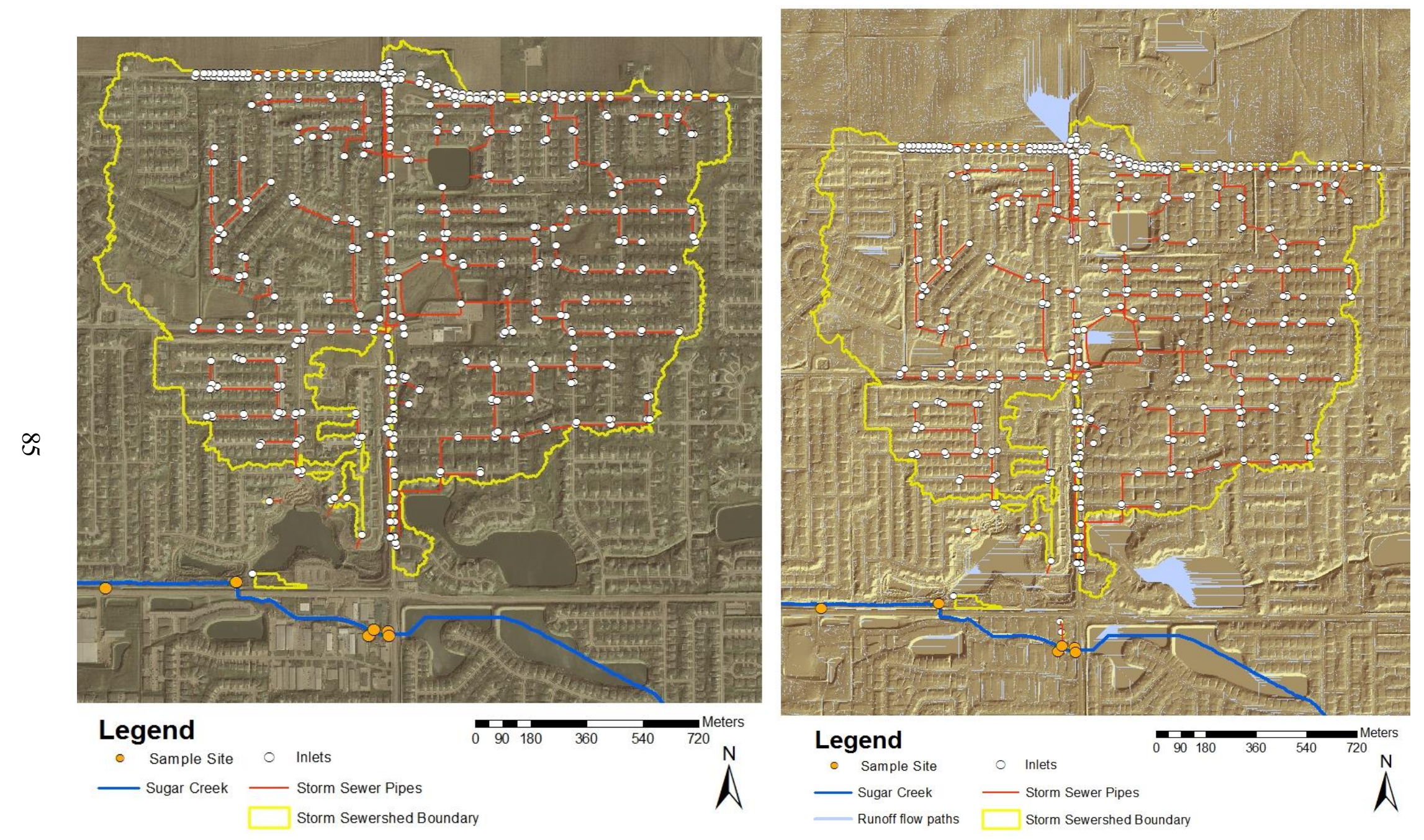


\section{Commercial Drainage at Veteran's Parkway}

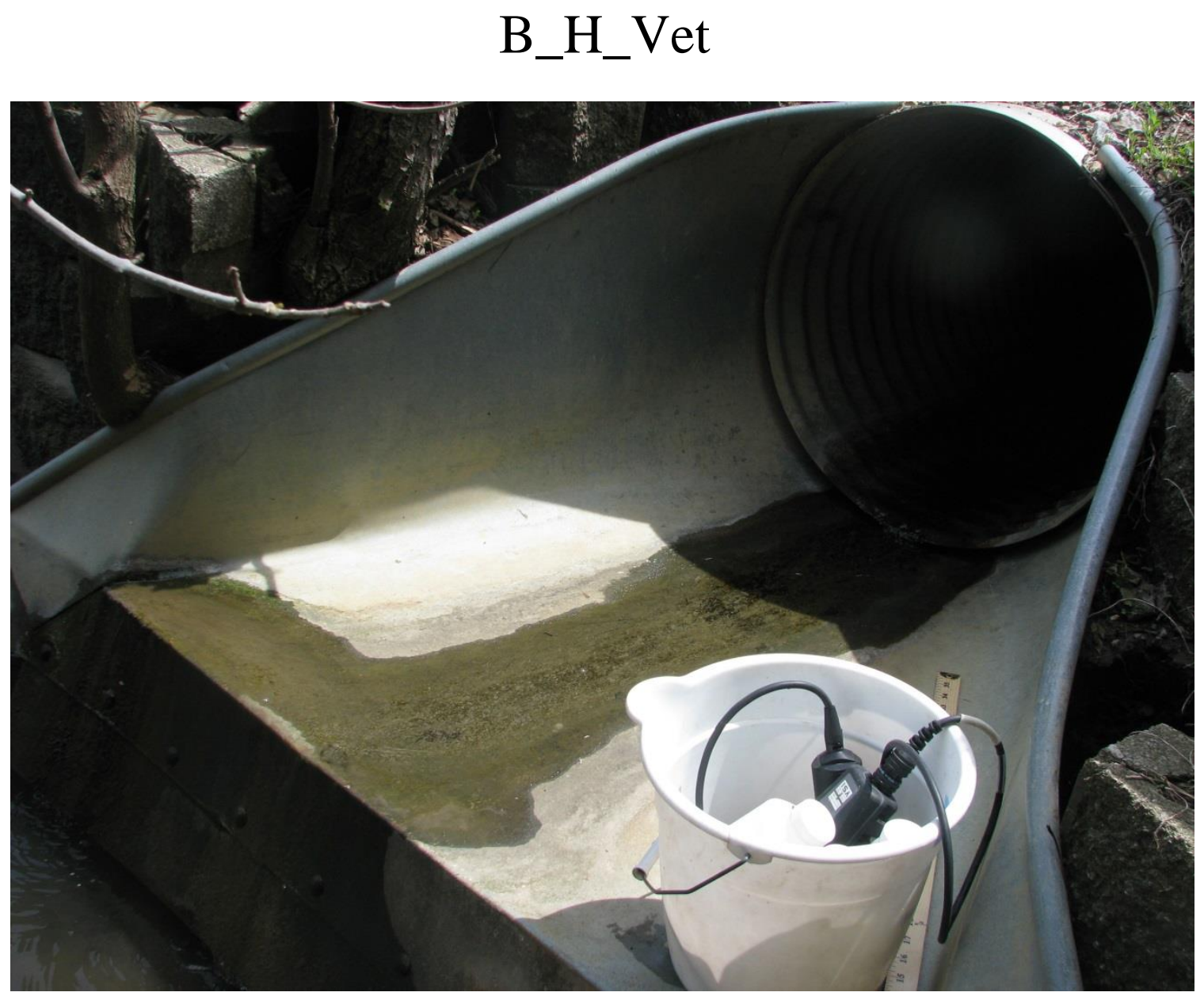

This is a public storm sewer system. The outlet pipe is 24 inches in diameter. The system drains a commercial areas south of Sugar Creek. I accessed this location from Jason's Deli on Vernon St. From this parking lot there is access to the Constitution Trail. This location is upstream from the access point. Immediately after passing under the Veteran's Parkway Bridge this site is located on the south side of the stream. I climbed down to this site using the bricks for the bridge. The site has a metal tongue. 

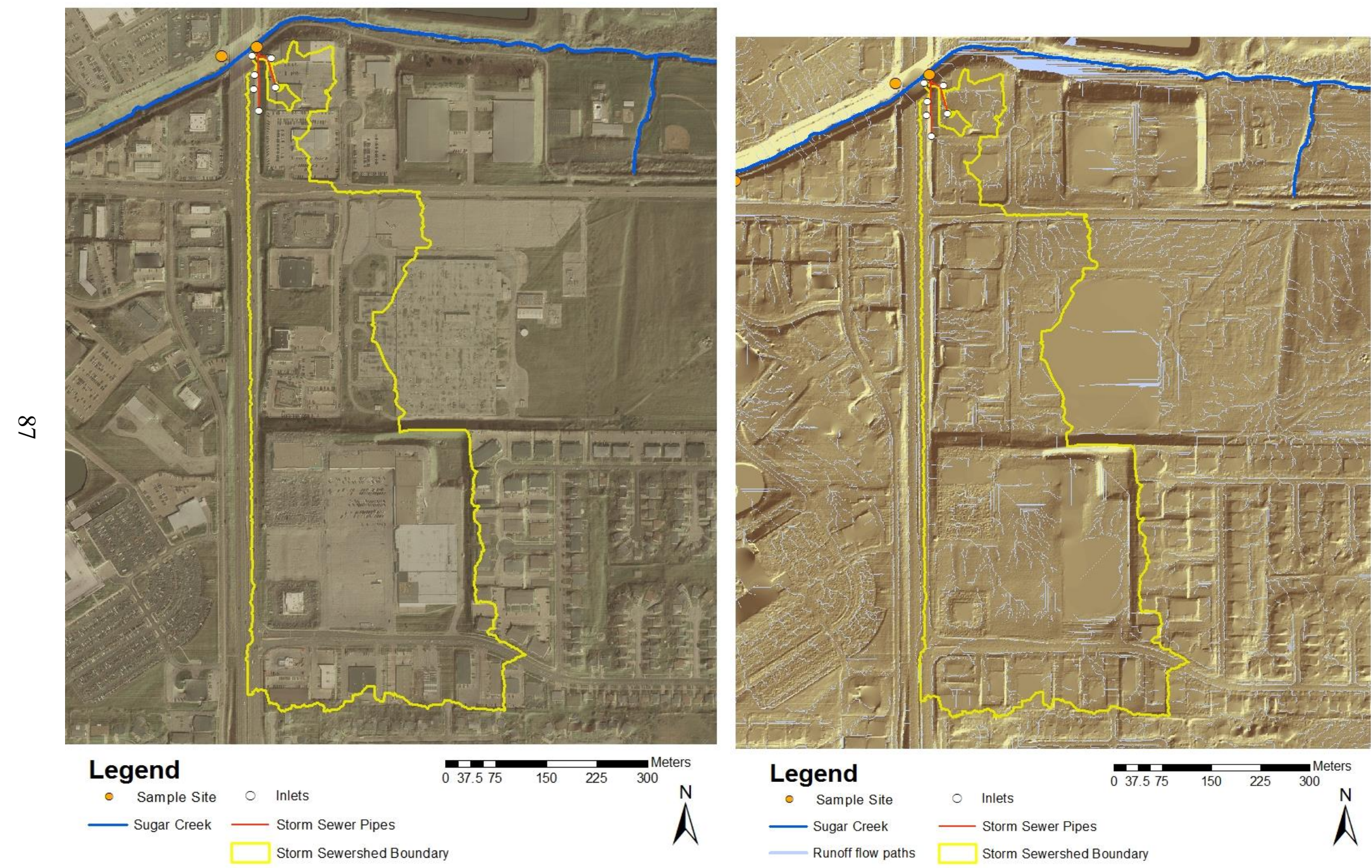


\section{Low Impervious Surface at Ewing Park}

\section{B_ISC_EW}

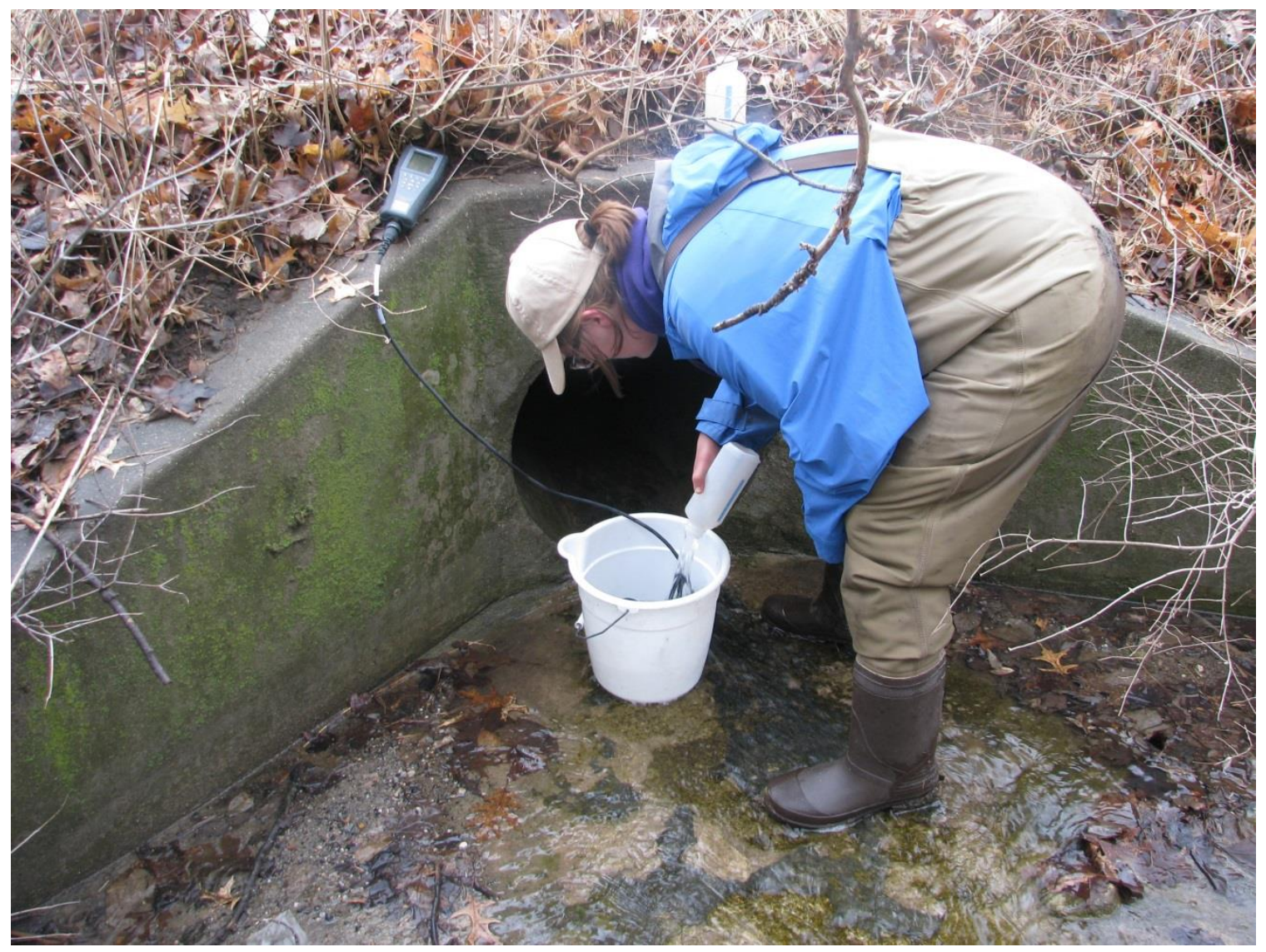

This is a public storm sewer system. The outlet pipe is 21 inches in diameter. The system drains the baseball fields of Ewing Park and a residential area to the south. I accessed this site from Ewing Park II off of Ethel Parkway. This site is located on the south side of the stream just after the site becomes cement lined. 

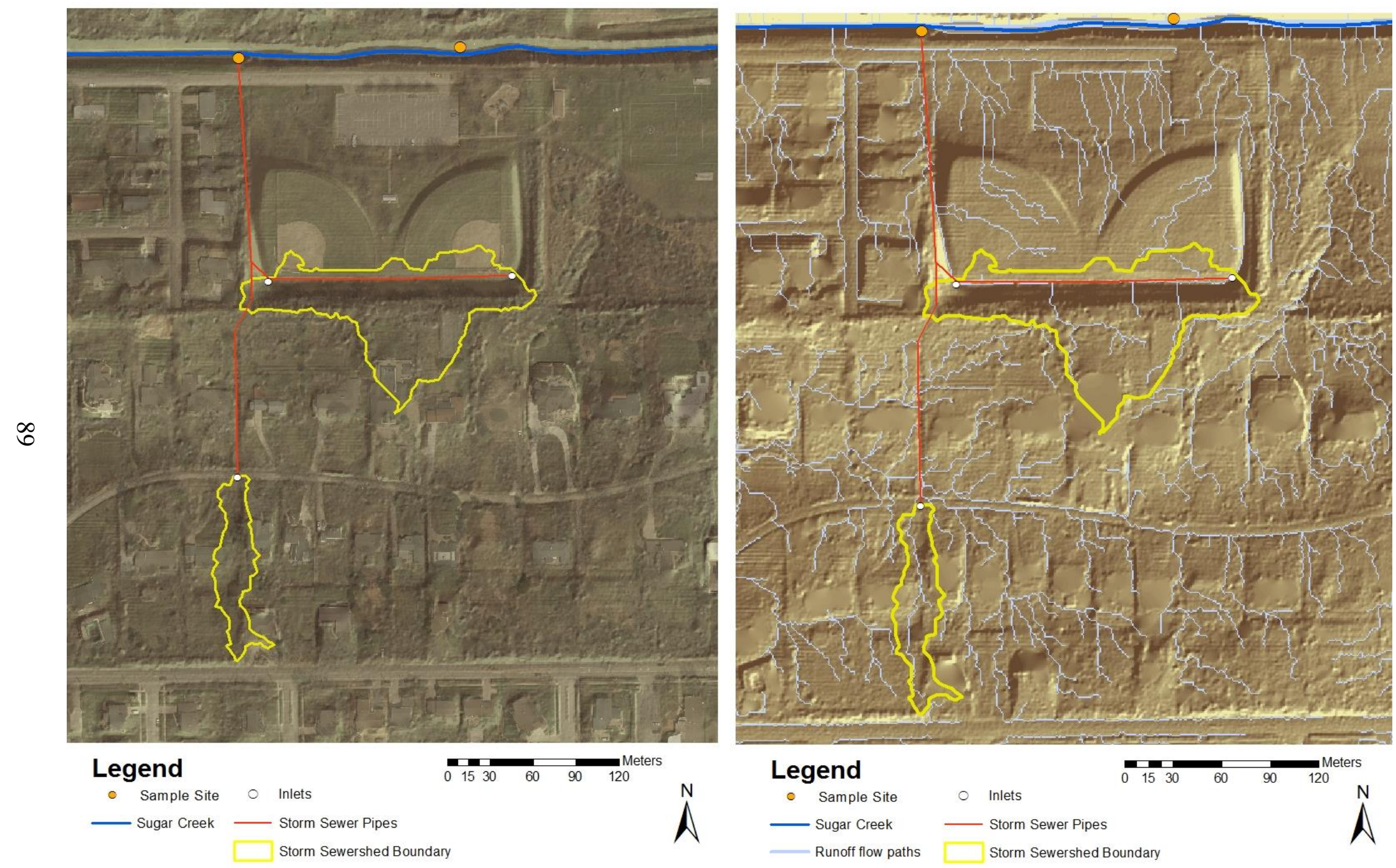


\section{Long Range Drainage at General Electric}

\section{B_L_GE}

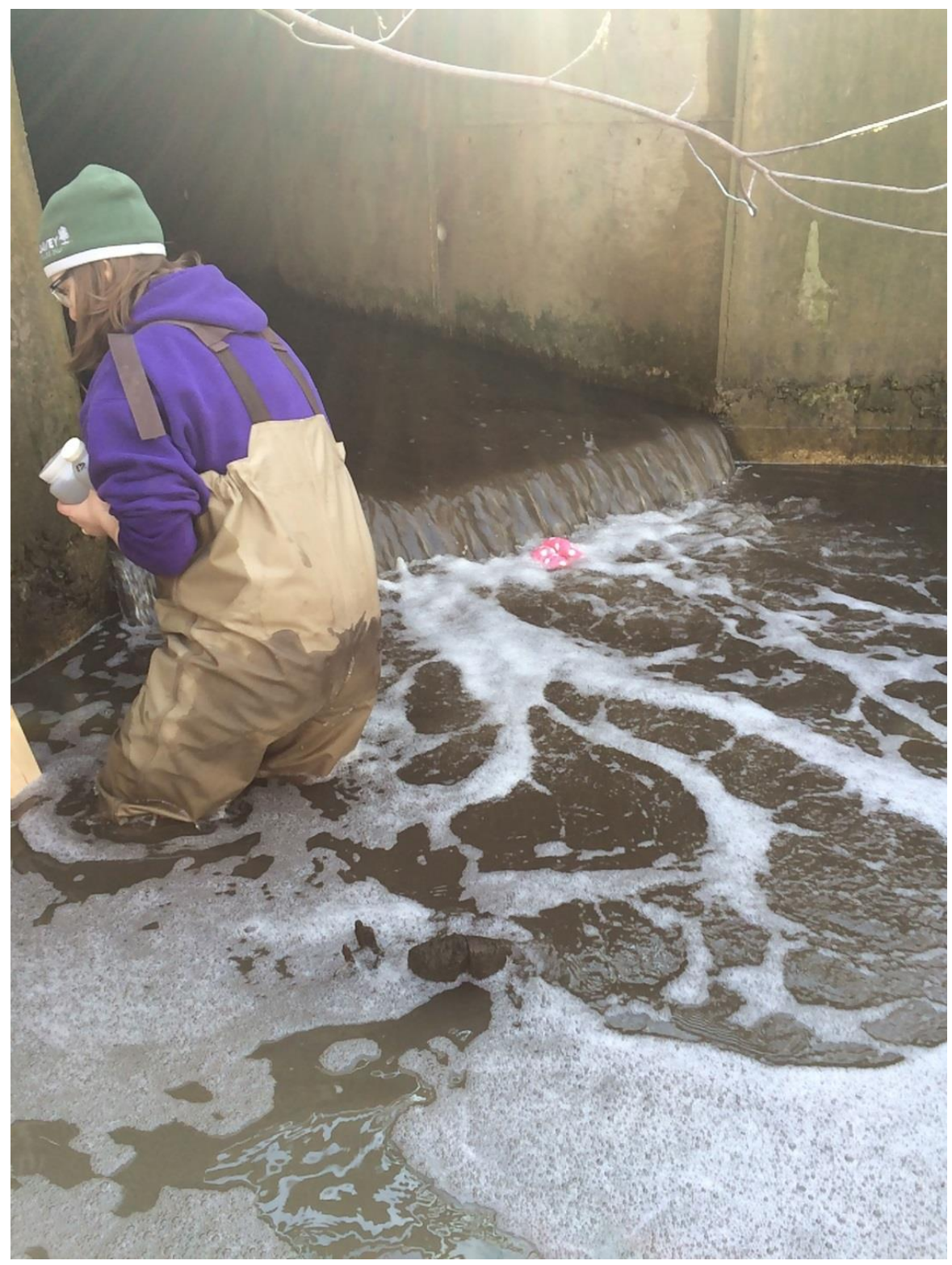

This is a public sewer system. The outlet pipe is 72 inches square. It drains a residential area south of Sugar Creek near the intersection of Hershey Road and General Electric Road. I accessed this site from Hedgewood Park. This site is downstream of the access point. I travel under Hershey Road via the Constitution Trail. At the first fence post I climb into a large gully that the outlet creates. This is a square shaped outlet with no tongue. 

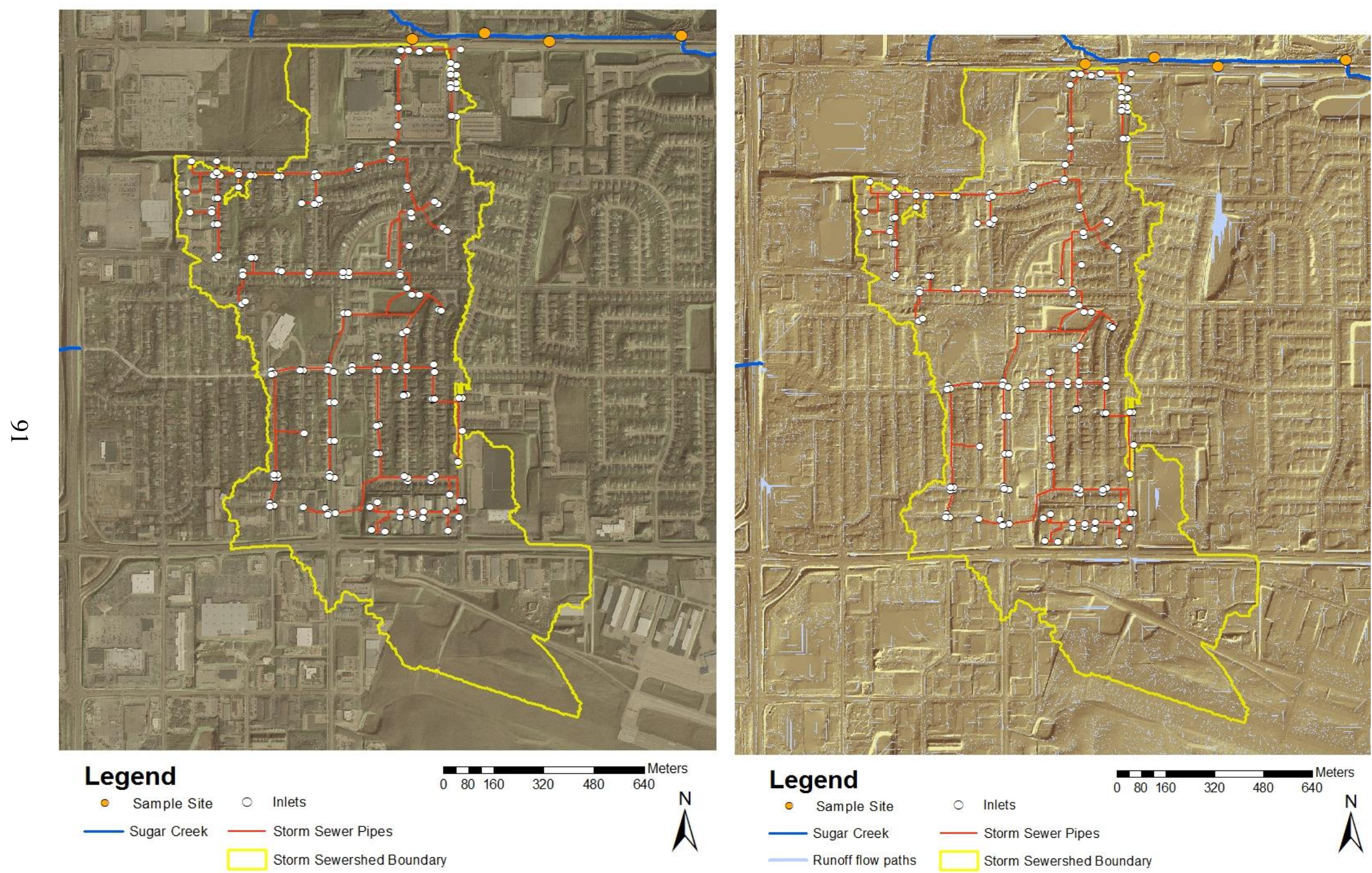


\section{Drainage from Airport Road}

\section{B_R_Airport}

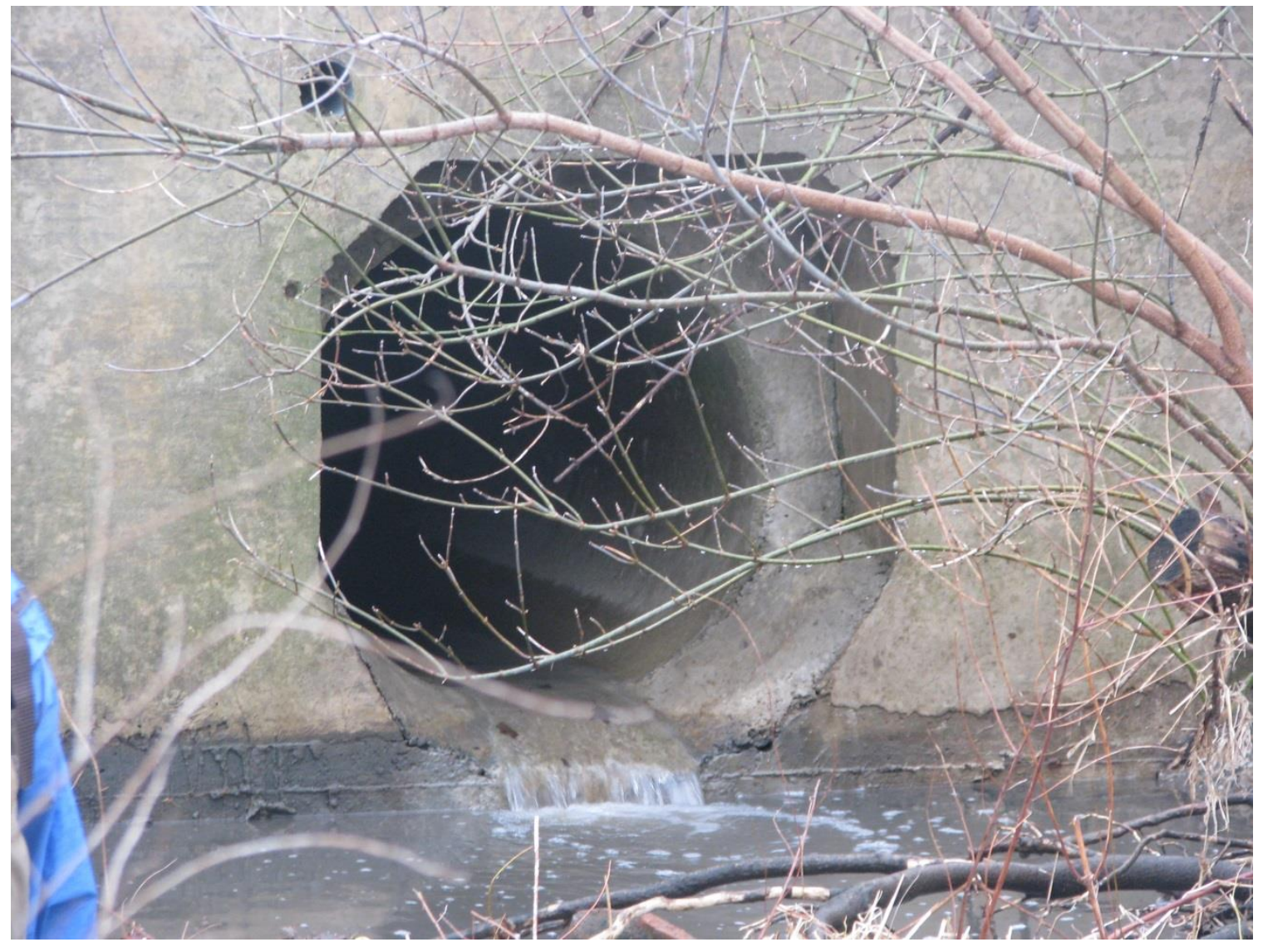

This is a public sewer system. The outlet pipe is 36 inches in diameter. It drains Airport Road south of General Electric Road. I accessed this site from the corner of Airport Road and General Electric Road. This site is across the stream from B_H_GEAir, on the south end of the bridge. 

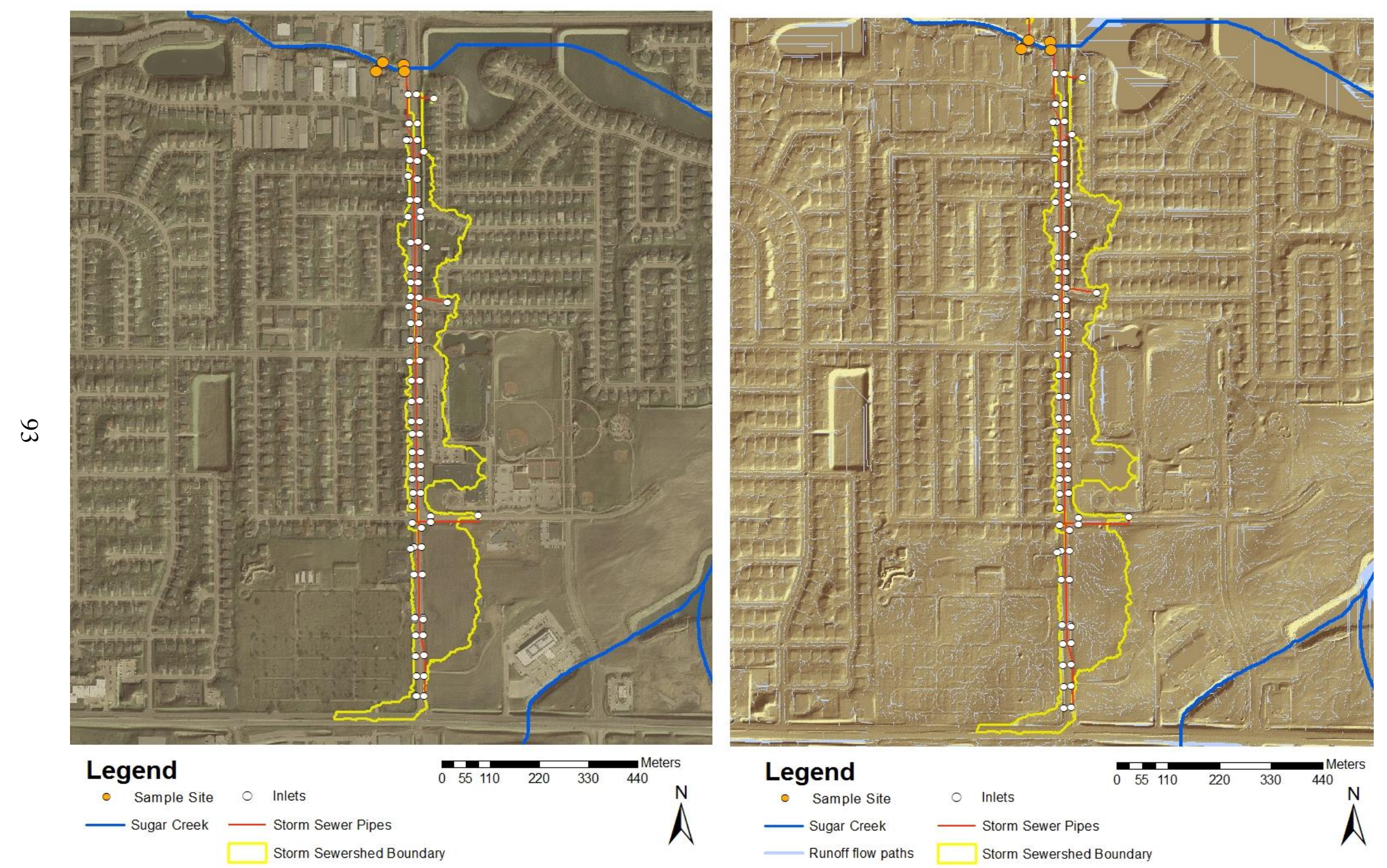


\section{Drainage from Cottage Street}

\section{B_R_Cott}

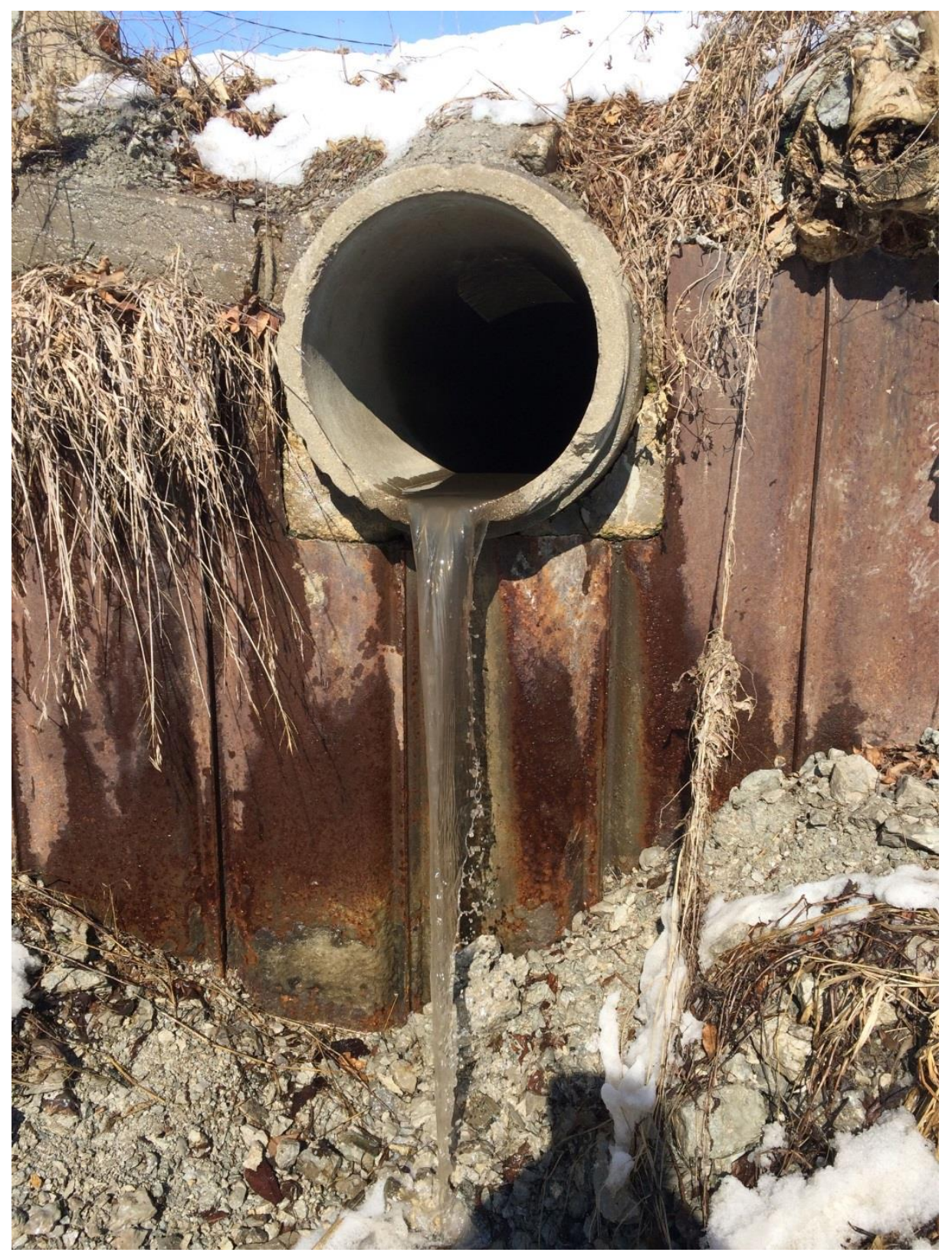

This is a public storm sewer system located on the north side of Sugar Creek. The outlet pipe is 21 inches in diameter. This site drains Cottage Road north of White Oak Park. I accessed this site from White Oak Park. From the parking lot I walk underneath the Cottage Road bridge over Sugar Creek. The outlet is located on the north side. The outlet pipe sticks out a few feet and hangs 5 feet from the ground. 

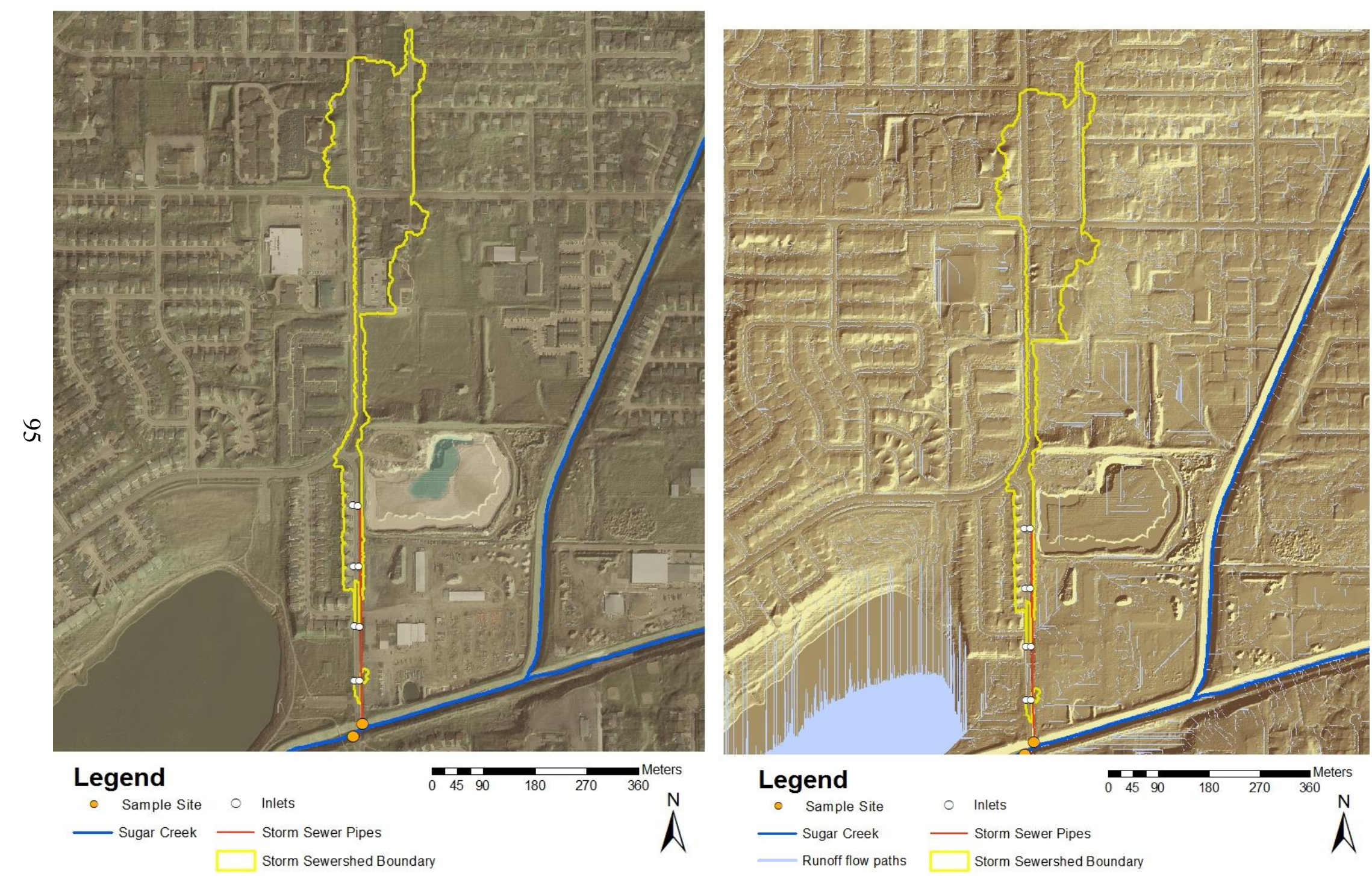


\section{Drainage from Emerson Street}

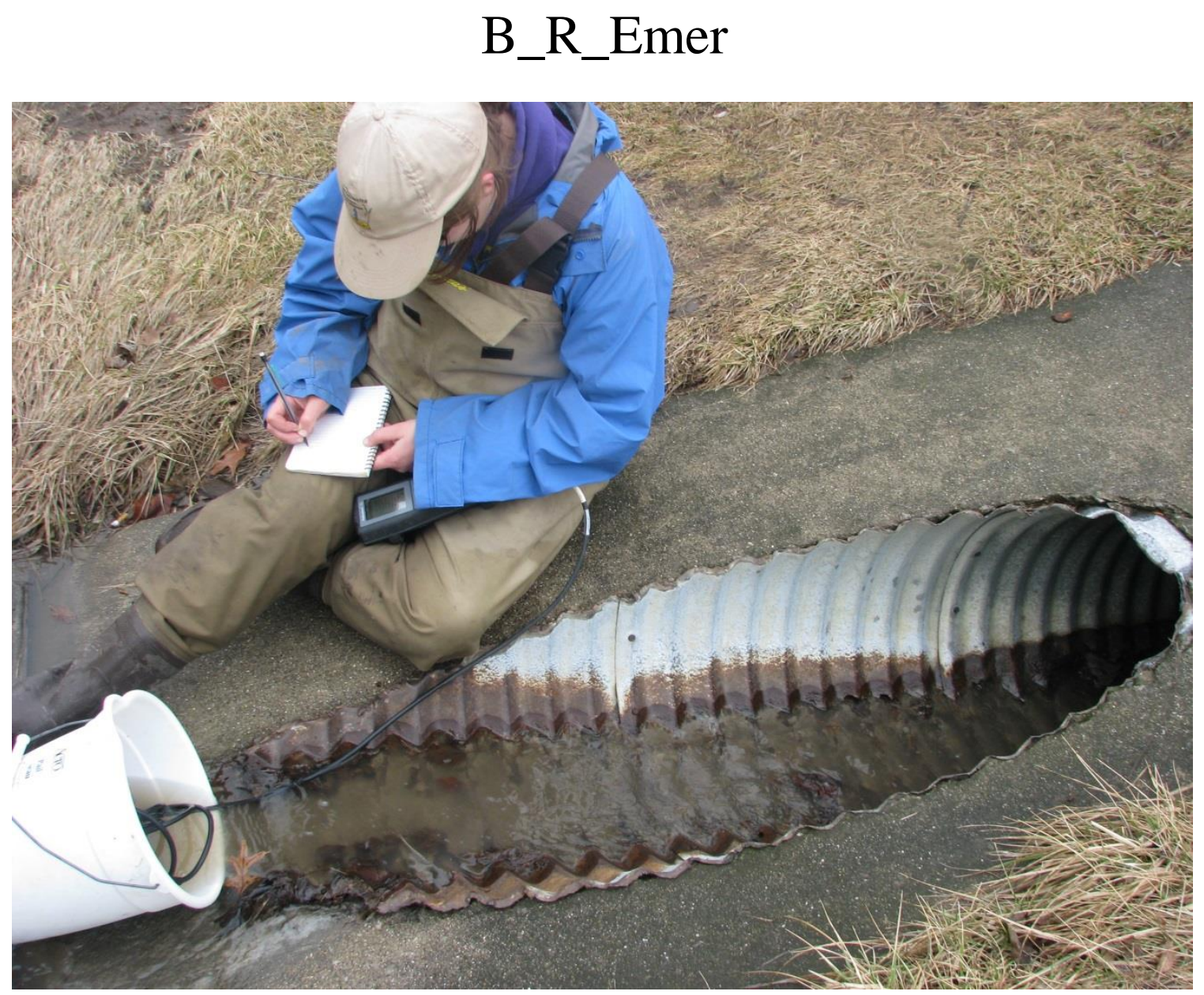

This is a public sewer systems located on the south side of Sugar Creek. The outlet pipe is 18 inches. This site drains Emerson St. east of Linden St. I accessed this site from the Bloomington Bible Church parking lot. The outlet is near a big tree on the north side of the parking lot. 


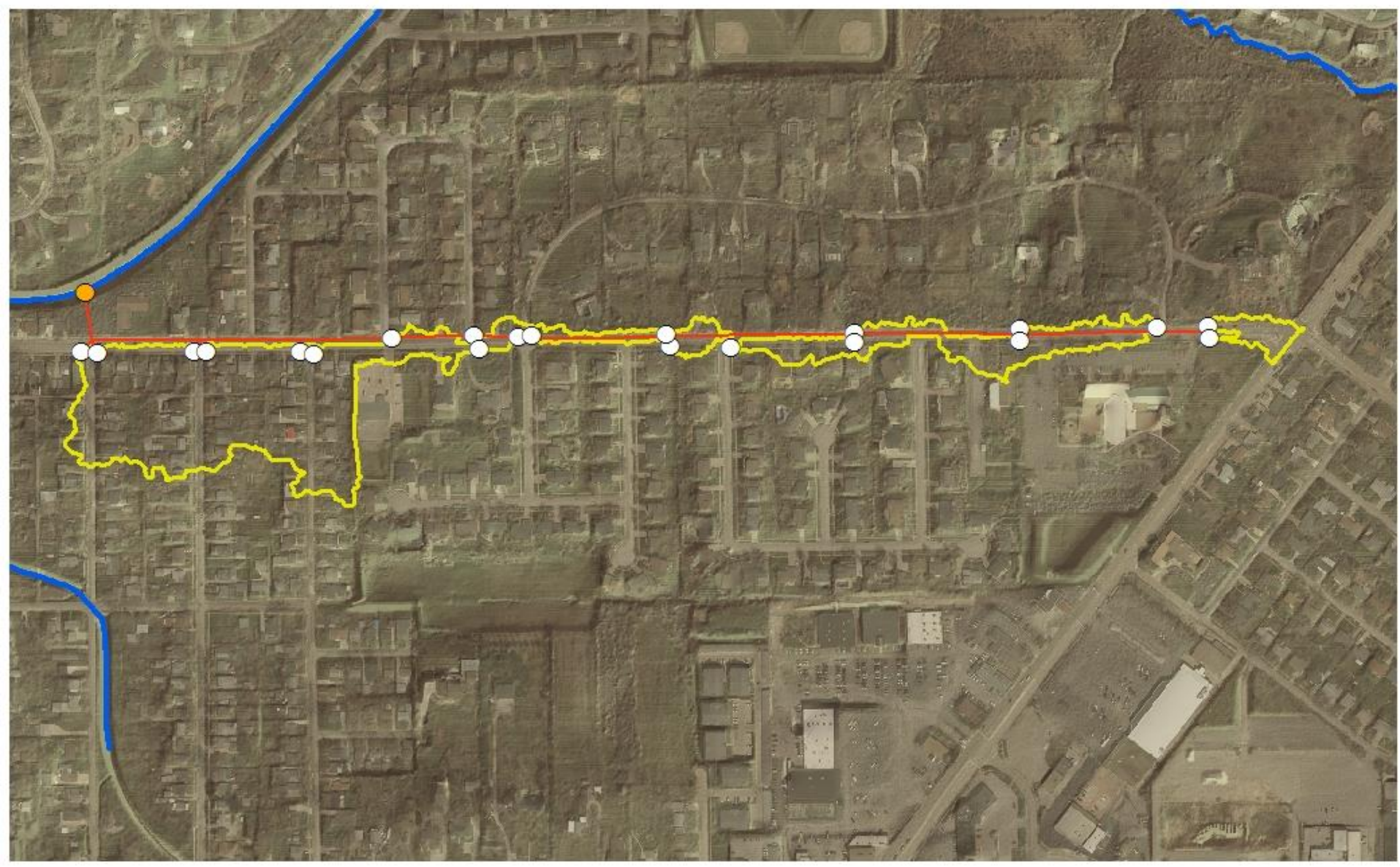

\section{Legend}

- Sample Site

- Inlets

$\begin{array}{llllll}0 & 40 & 80 & 160 & 240 & 320\end{array}$

— Sugar Creek

$N$

Storm Sewershed Boundary 


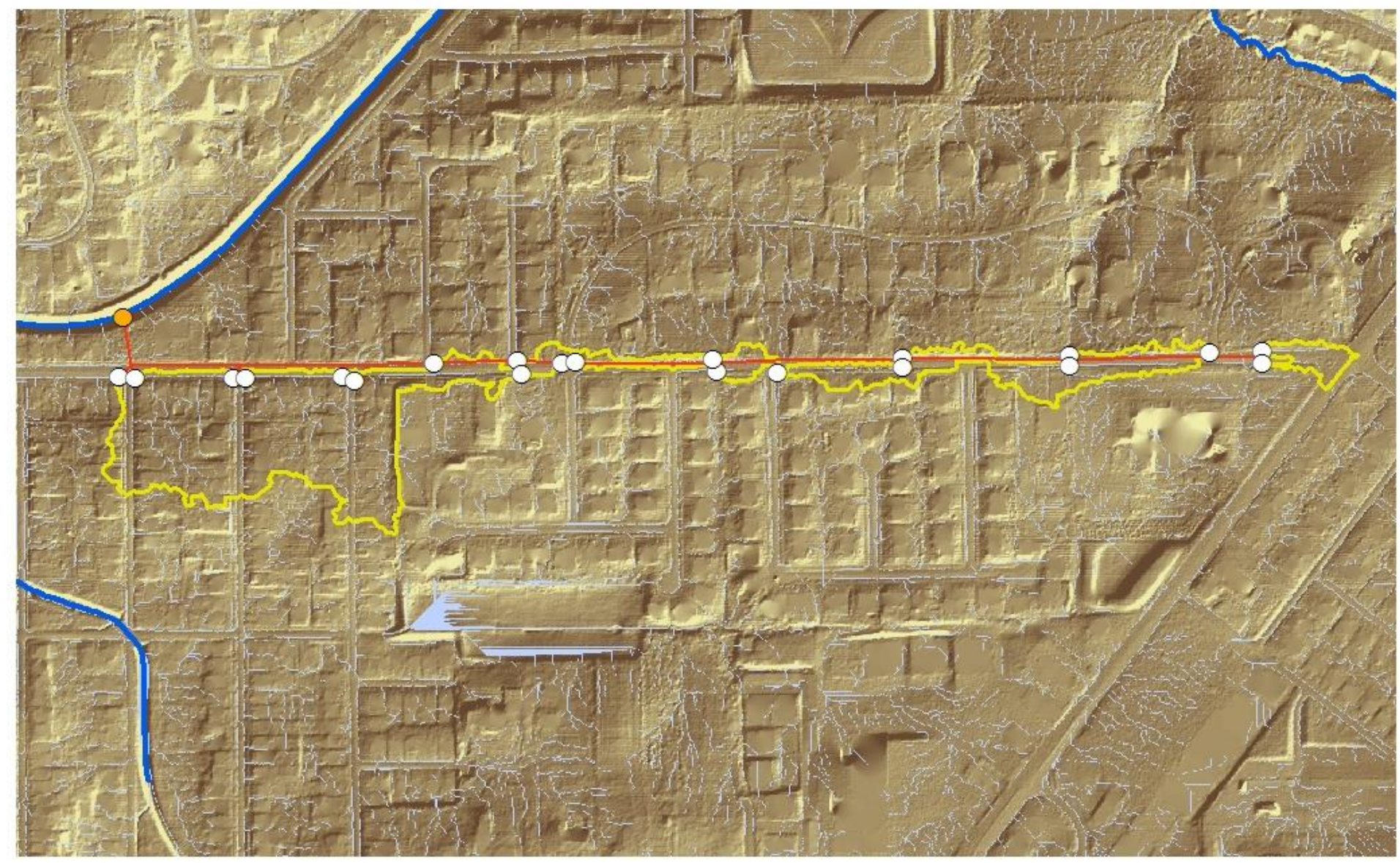

\section{Legend}

- Sample Site

_ Sugar Creek

Runoff flow paths
- Inlets

Storm Sewer Pipes

Storm Sewershed Boundary

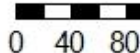

$160 \quad 240$
320

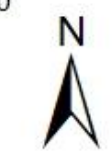




\section{Drainage from Veteran's Parkway}

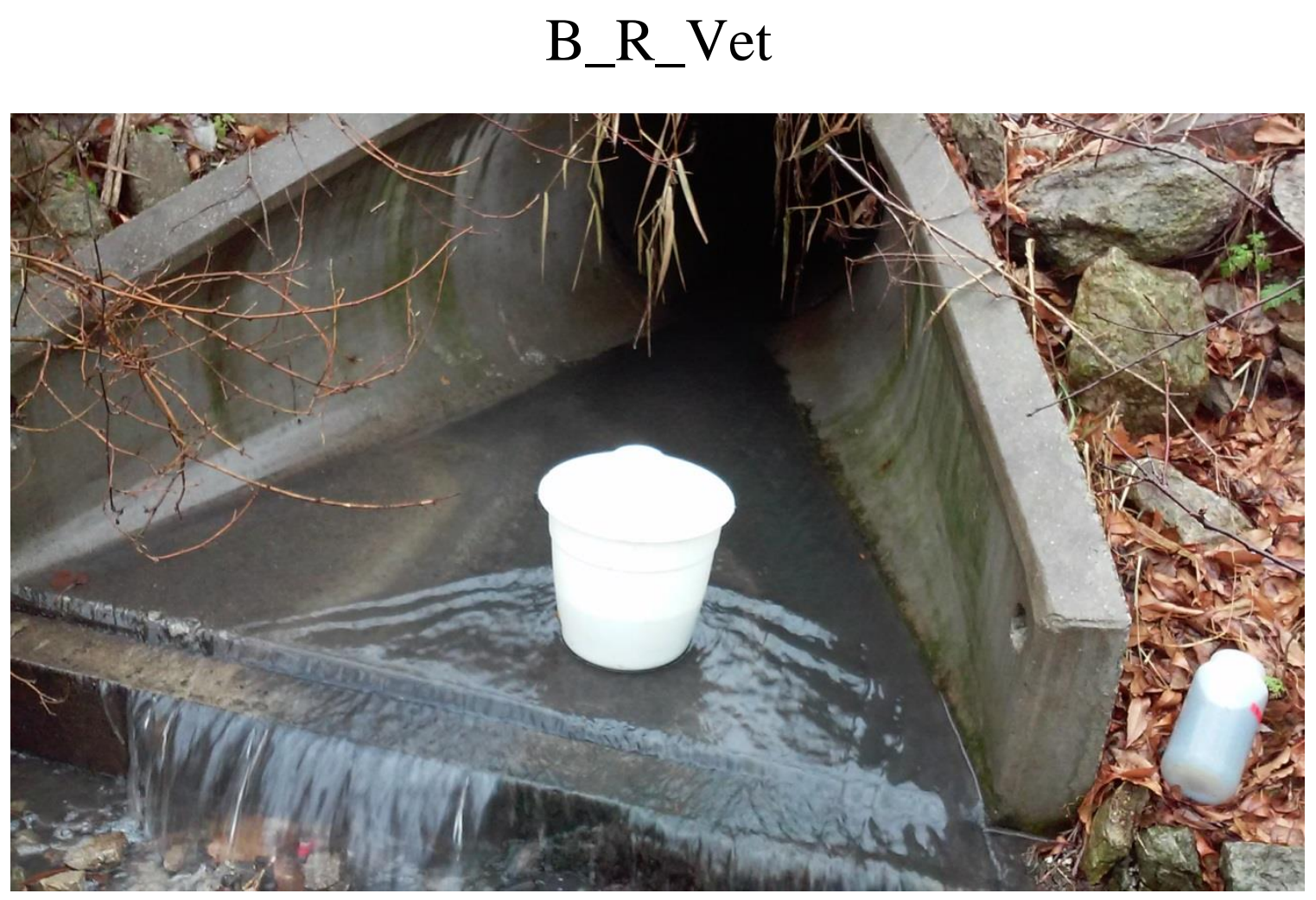

This is a public sewer system located on the north side of Sugar Creek. The outlet pipe is 30 inches in diameter. This site drains Veteran's Parkway north of IAA drive. To access this site I parked at Jason's Deli and walked down to the constitution trail. Enter the stream at B_H_Vet and walk down stream under the Veteran's Parkway bridge. Immediately after the bridge climb the riprap to the north and the outlet will be at the top there the Hampton Inn and Suites Sign 


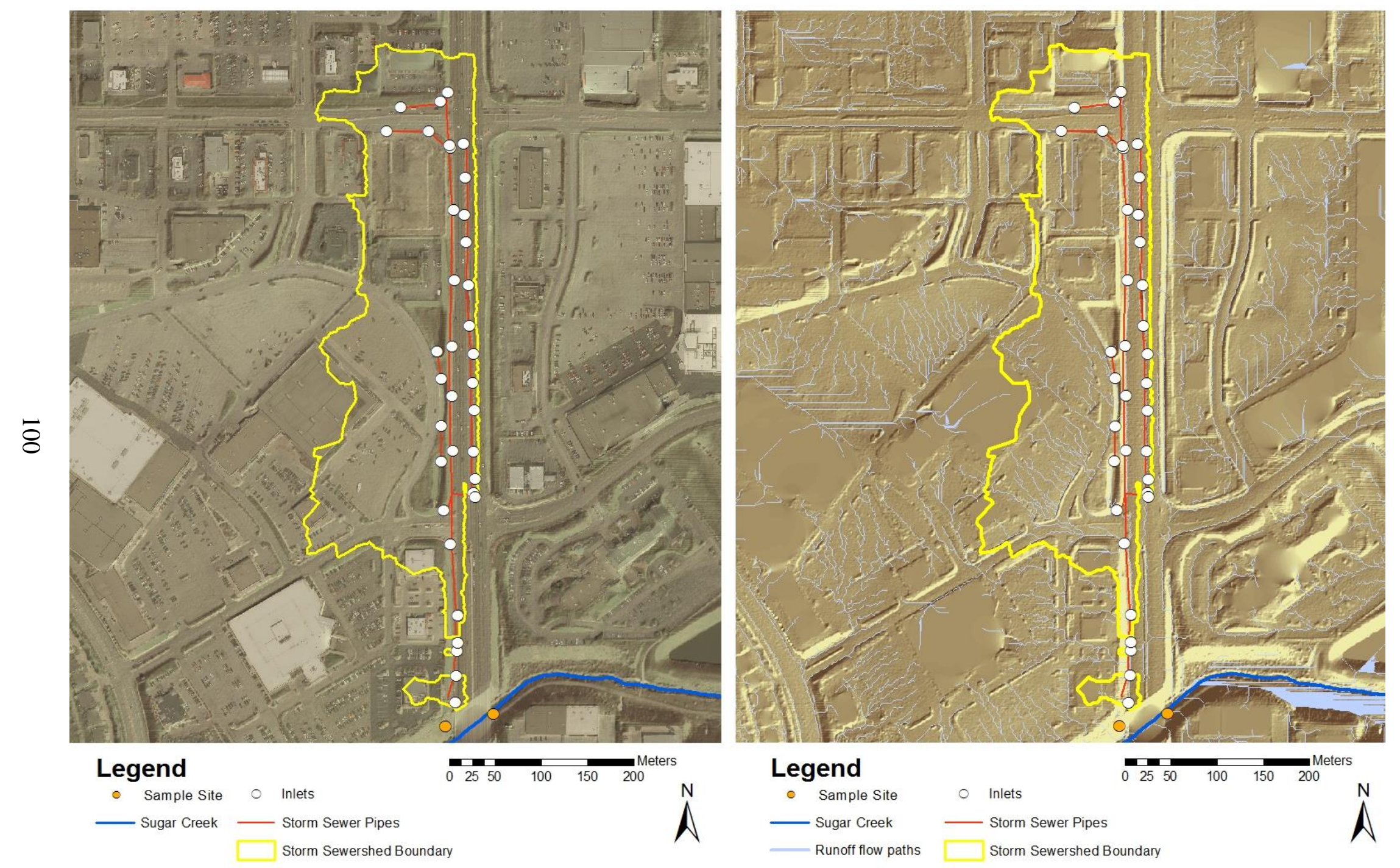


APPENDIX B

STORM SEWERSHED CHARACTERISTICS 


\begin{tabular}{|c|c|c|c|c|c|c|c|}
\hline$\underline{\text { Site }}$ & $\underline{\underline{\text { Inlets }}} \underline{\text { counts })}$ & $\begin{array}{c}\underline{\text { Inlet }} \\
\underline{\text { Density }} \\
\text { (per km²) }\end{array}$ & $\frac{\underline{\text { Pipe }}}{\underline{\text { Diameter }}} \frac{(\mathrm{cm})}{\underline{(n)}}$ & $\frac{\frac{\text { Max. }}{\text { Snap }}}{\frac{\underline{\text { Distance }}}{(\mathrm{m})}}$ & $\frac{\text { Pipe length }}{\underline{\text { (meters) }}}$ & $\begin{array}{l}\underline{\text { Pipe }} \\
\underline{\text { Density }} \\
\underline{(\mathrm{m} / \mathrm{sq} \mathrm{m})}\end{array}$ & $\frac{\text { Area }}{\left(\mathrm{m}^{2}\right)}$ \\
\hline B_C_Airport & 2 & 10826 & 30 & 1.5 & 94 & $5.13 \mathrm{E}-01$ & 184 \\
\hline B_C_GE & 8 & 109 & 121 & 3.8 & 7297 & $1.00 \mathrm{E}-01$ & 72872 \\
\hline B_C_Vernon & 8 & 248 & 45 & 4.6 & 552 & $1.72 \mathrm{E}-02$ & 32166 \\
\hline B_H_Airport & 34 & 113 & 137 & 3.0 & 2099 & 7.03E-03 & 298462 \\
\hline B_H_Cott & 13 & 213 & 60 & 1.5 & 467 & 7.67E-03 & 60977 \\
\hline B_H_EW & 8 & 196 & 30 & 2.3 & 363 & 8.90E-03 & 40810 \\
\hline B_H_GE & 41 & 187 & 106 & 3.8 & 2224 & $1.02 \mathrm{E}-02$ & 218408 \\
\hline B_H_GEAir & 175 & 166 & 182 & 1.5 & 7794 & $7.42 \mathrm{E}-03$ & 1050242 \\
\hline B_H_Jersey & 2 & 140 & 30 & 1.5 & 90 & $6.38 \mathrm{E}-03$ & 14205 \\
\hline B_H_Rowe & 18 & 167 & 38 & 2.3 & 456 & $4.26 \mathrm{E}-03$ & 107269 \\
\hline B_H_Tipton & 463 & 214 & 364 & 3.0 & 21236 & $9.82 \mathrm{E}-03$ & 2162726 \\
\hline B_H_Vet & 6 & 25 & 60 & 1.6 & 184 & 7.72E-04 & 238756 \\
\hline B_ISC_EW & 3 & 241 & 53 & 3.0 & 483 & $3.90 \mathrm{E}-02$ & 12401 \\
\hline B_L_GE & 173 & 117 & 182 & 2.3 & 9135 & $6.19 \mathrm{E}-03$ & 1476493 \\
\hline B_R_Airport & 74 & 590 & 91 & 3.8 & 2425 & $1.93 \mathrm{E}-02$ & 125397 \\
\hline B_R_Cott & 8 & 125 & 53 & 2.3 & 427 & $6.68 \mathrm{E}-03$ & 63939 \\
\hline B_R_Emer & 21 & 394 & 45 & 3 & 1271 & 2.39E-02 & 53176 \\
\hline B_R_Vet & 36 & 442 & 76 & 2.3 & 1359 & $1.67 \mathrm{E}-02$ & 81337 \\
\hline
\end{tabular}




\begin{tabular}{|c|c|c|c|c|c|c|c|c|c|}
\hline$\underline{\text { Site }}$ & Pond & $\begin{array}{l}\text { Sump } \\
\text { Pump }\end{array}$ & $\underline{\text { ISC }}$ & $\begin{array}{l}\underline{\mathrm{ISC}} \\
(\mathrm{sq} \mathrm{m})\end{array}$ & \%ISC & \% Com & \% Res & $\underline{\frac{\%}{O p e n}}$ & $\underline{\frac{\%}{\text { Road }}}$ \\
\hline B_C_Airport & No & $\mathrm{No}$ & Yes & 122 & $66.0 \%$ & $100.0 \%$ & $0.0 \%$ & $0.0 \%$ & $\overline{0.0 \%}$ \\
\hline B_C_GE & Yes & No & Yes & 20097 & $27.6 \%$ & $51.7 \%$ & $8.3 \%$ & $0.0 \%$ & $40.0 \%$ \\
\hline B_C_Vernon & Yes & Yes & Yes & 19948 & $62.0 \%$ & $73.6 \%$ & $0.0 \%$ & $0.0 \%$ & $26.4 \%$ \\
\hline B_H_Airport & No & Yes & No & 77467 & $26.0 \%$ & $0.8 \%$ & $38.9 \%$ & $43.2 \%$ & $17.0 \%$ \\
\hline B_H_Cott & No & Yes & No & 15851 & $26.0 \%$ & $0.0 \%$ & $61.1 \%$ & $11.5 \%$ & $27.4 \%$ \\
\hline B_H_EW & No & No & No & 12704 & $31.1 \%$ & $0.0 \%$ & $40.9 \%$ & $4.0 \%$ & $11.1 \%$ \\
\hline B_H_GE & No & Yes & No & 58567 & $26.8 \%$ & $0.0 \%$ & $72.3 \%$ & $2.5 \%$ & $25.2 \%$ \\
\hline B_H_GEAir & Yes & Yes & Yes & 263678 & $25.1 \%$ & $3.7 \%$ & $73.3 \%$ & $0.2 \%$ & $22.8 \%$ \\
\hline B_H_Jersey & No & No & No & 4905 & $34.5 \%$ & $0.0 \%$ & $70.6 \%$ & $0.0 \%$ & $29.4 \%$ \\
\hline B_H_Rowe & No & Yes & No & 38719 & $36.1 \%$ & $1.5 \%$ & $73.5 \%$ & $0.0 \%$ & $25.0 \%$ \\
\hline B_H_Tipton & Yes & Yes & Yes & 563683 & $26.1 \%$ & $0.0 \%$ & $72.7 \%$ & $8.2 \%$ & $19.1 \%$ \\
\hline B_H_Vet & Yes & No & No & 168906 & $70.7 \%$ & $82.2 \%$ & $1.6 \%$ & $0.0 \%$ & $16.2 \%$ \\
\hline B_ISC_EW & No & Yes & Yes & 1193 & $9.6 \%$ & $0.0 \%$ & $51.1 \%$ & $48.3 \%$ & $0.6 \%$ \\
\hline B_L_GE & Yes & Yes & No & 545820 & $37.0 \%$ & $22.8 \%$ & $42.6 \%$ & $11.8 \%$ & $22.8 \%$ \\
\hline B_R_Airport & No & No & No & 15977 & $12.7 \%$ & $33.8 \%$ & $18.7 \%$ & $25.7 \%$ & $21.9 \%$ \\
\hline B_R_Cott & No & No & Yes & 19350 & $30.3 \%$ & $0.0 \%$ & $5.1 \%$ & $0.0 \%$ & $19.6 \%$ \\
\hline B_R_Emer & No & No & No & 19358 & $36.4 \%$ & $0.0 \%$ & $57.0 \%$ & $0.6 \%$ & $42.5 \%$ \\
\hline B_R_Vet & No & No & No & 55952 & $68.8 \%$ & & & & $33.0 \%$ \\
\hline
\end{tabular}


APPENDIX C

RAW CHEMISTY DATA 


\begin{tabular}{|c|c|c|c|c|c|c|c|c|c|c|c|c|c|c|c|}
\hline$\underline{\text { Sample ID }}$ & $\underline{\text { Date }}$ & $\underline{\text { Time }}$ & $\frac{\text { Depth }}{\underline{\text { (in) }}}$ & $\underline{\mathrm{pH}}$ & $\frac{\text { Temp }}{\underline{\left({ }^{\circ} \mathrm{C}\right)}}$ & $\underline{\underline{(\mu P C}}$ & $\underline{\underline{\mathrm{DO}}} \underline{\underline{\mathrm{mg} / \mathrm{L}})}$ & $\frac{\mathrm{DO}}{\underline{(\%)}}$ & $\underline{\underline{\mathrm{TSS}}} \underline{\underline{\mathrm{mg} / \mathrm{L})}}$ & $\underline{\underline{\mathrm{VSS}}} \underline{\underline{\mathrm{mg} / \mathrm{L}})}$ & $\frac{\mathrm{PO}_{4}=}{\frac{(\mu \mathrm{g} / \mathrm{L}-}{\underline{\mathrm{P}}}}$ & $\frac{\frac{\mathrm{NH}_{3}}{\mathrm{mg} / \mathrm{L}-}}{\underline{\mathrm{N})}}$ & $\frac{\frac{\mathrm{NO}_{3}}{\mathrm{mg} / \mathrm{L}}-}{\underline{\mathrm{N})}}$ & $\frac{\frac{\mathrm{TP}}{(\mathrm{mg} / \mathrm{L}-}}{\underline{\mathrm{P})}}$ & $\underline{\underline{(\mathrm{mg} / \mathrm{L})}}$ \\
\hline B_C_Airport & $5 / 9 / 14$ & $10: 48$ & $<0.125$ & 8.51 & 17.5 & 1119 & 9.14 & 95.51 & 14.81 & 3.05 & 97.9 & 0.0551 & 1.91 & & 223.6 \\
\hline B_C_GE & $5 / 9 / 14$ & $10: 10$ & 0.25 & 7.51 & 17.8 & 536.5 & 4.70 & 36.52 & 24.95 & 13.56 & 123 & 0.04 & 2.03 & 276 & 80.262 \\
\hline B_C_Vernon & $5 / 9 / 14$ & $12: 57$ & $<0.125$ & 7.76 & 18.1 & 584 & 8.09 & 85.61 & 7.39 & 4.55 & 7.15 & 0.225 & 0.458 & & 79.504 \\
\hline B_H_Airport & $5 / 9 / 14$ & $10: 56$ & 0.625 & 7.85 & 14.1 & 635 & 8.42 & 81.91 & 8.23 & 2.33 & 10.5 & 0.122 & 1.58 & & 107.08 \\
\hline B_H_Cott & $5 / 9 / 14$ & 14:00 & & & & & & & & & & & & & \\
\hline B_H_EW & $5 / 9 / 14$ & $13: 24$ & $<0.125$ & 7.77 & 14.4 & 713 & 9.69 & 94.81 & 12.88 & 4.18 & 67.2 & 0.0767 & 1.08 & & 182.48 \\
\hline B_H_GE & $5 / 9 / 14$ & 10:00 & 0.875 & 7.89 & 15.7 & 766 & 8.13 & 81.87 & 120.96 & 26.54 & 11 & 0.0571 & 1.39 & & 171.52 \\
\hline B_H_GEAir & $5 / 9 / 14$ & 11:06 & 2.5 & 7.72 & 15.3 & 738 & 8.47 & 84.53 & 6.48 & 4.10 & 4.38 & 0.0247 & 0.289 & & 140.77 \\
\hline B_H_Jersey & $5 / 9 / 14$ & $12: 52$ & $<0.125$ & 7.82 & 14.7 & 2054 & 9.36 & 92.22 & 16.59 & 7.23 & 19.2 & 0.0631 & 0.868 & & 530.61 \\
\hline B_H_Rowe & $5 / 9 / 14$ & 13:09 & 0.125 & 7.93 & 14.8 & 946 & 10.14 & 100.1 & 7.53 & 3.87 & 11.8 & 0.0192 & 1.28 & & 182.65 \\
\hline B_H_Tipton & $5 / 9 / 14$ & $11: 29$ & 0.75 & 8.06 & 20.4 & 891 & 8.00 & 88.69 & 11.54 & 7.15 & 10.1 & 0.0116 & 0.143 & & 183.27 \\
\hline B_H_Vet & $5 / 9 / 14$ & $12: 32$ & 0.125 & 7.84 & 14.2 & 1587 & 10.38 & 101.1 & 9.07 & 3.07 & 9.2 & 0.0374 & 1.11 & & 411.05 \\
\hline B_ISC_EW & $5 / 9 / 14$ & $13: 36$ & 0.125 & 7.90 & 12.7 & 872 & 10.21 & 96.23 & 3.40 & 1.38 & 6.09 & 0.0177 & 1.68 & & 74.254 \\
\hline B_L_GE & $5 / 9 / 14$ & $10: 20$ & 0.5 & 7.57 & 15.3 & 1075 & 8.85 & 88.32 & 14.80 & 4.61 & 13.7 & 0.0667 & 1.14 & & 310.75 \\
\hline B_R_Airport & $5 / 9 / 14$ & $11: 15$ & & 7.77 & 13.6 & 927 & 8.00 & 76.92 & 7.45 & 2.34 & 23.6 & 0.297 & 1.51 & & 214.75 \\
\hline B_R_Cott & $5 / 9 / 14$ & $15: 18$ & $<0.125$ & 7.69 & 15.2 & 1211 & 10.44 & 103.9 & 21.48 & 7.89 & 14.6 & 0.109 & 1.57 & & 254.51 \\
\hline B_R_Emer & $5 / 9 / 14$ & $13: 49$ & 0.625 & 8.00 & 15.9 & 1484 & 7.99 & 80.79 & 18.60 & 7.83 & 15.7 & 0.104 & 1.36 & & 503.8 \\
\hline $\begin{array}{l}\text { B_R_Vet } \\
\text { DUP }\end{array}$ & $5 / 9 / 14$ & $12: 14$ & $<0.125$ & 7.81 & 13.1 & 3362 & 10.37 & 98.67 & 4.45 & 2.23 & 6.96 & 0.0117 & 1.58 & & 998.5 \\
\hline $\begin{array}{l}\text { B_C_Airport } \\
\text { DUP }\end{array}$ & $5 / 9 / 14$ & $10: 48$ & & & & & & & 14.96 & 3.32 & 20.1 & 2.42 & 0.331 & & 228.13 \\
\hline B_H_EW & $5 / 9 / 14$ & $13: 24$ & & & & & & & 12.82 & 4.07 & 79.7 & 0.0815 & 1.19 & & 171.26 \\
\hline
\end{tabular}




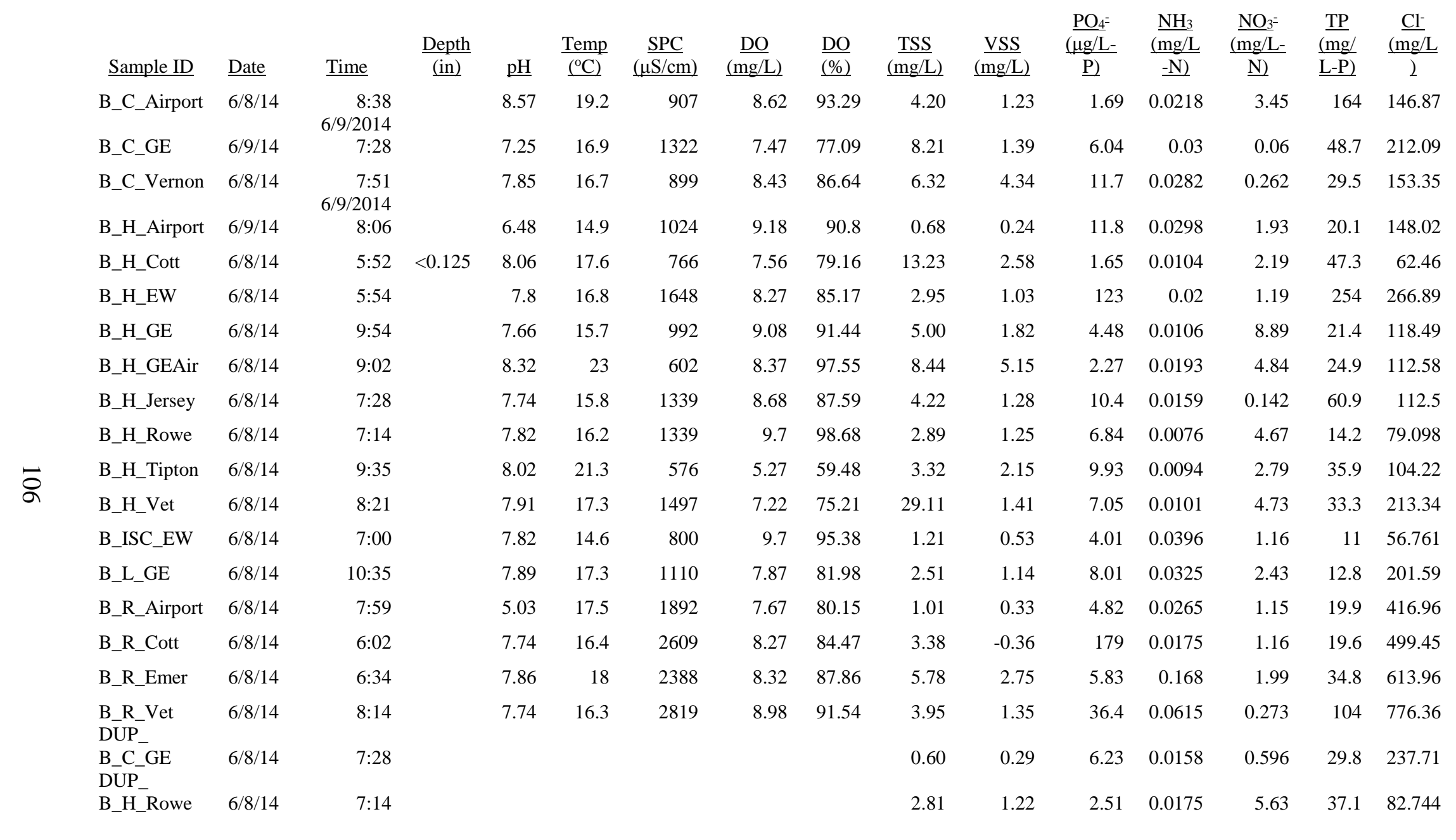




\begin{tabular}{|c|c|c|c|c|c|c|c|c|c|c|c|c|c|c|c|}
\hline$\underline{\text { Sample ID }}$ & $\underline{\text { Date }}$ & $\underline{\text { Time }}$ & $\frac{\text { Depth }}{\underline{\text { (in) }}}$ & $\underline{\mathrm{pH}}$ & $\frac{\text { Temp }}{\left({ }^{\circ} \mathrm{C}\right)}$ & $\begin{array}{c}\underline{\mathrm{SPC}} \\
(\mu \mathrm{S} / \mathrm{cm})\end{array}$ & $\underline{\underline{\mathrm{DO}}}$ & $\underline{\underline{\mathrm{DO}}}$ & $\underline{\underline{\mathrm{TSS}}}$ & $\underline{\underline{\mathrm{VSS}}}$ & $\frac{\mathrm{PO}_{4}=}{\frac{(\mu \mathrm{g} / \mathrm{L}}{-}}$ & $\frac{\frac{\mathrm{NH}_{3}}{(\mathrm{mg} / \mathrm{L}-}}{\underline{\mathrm{N})}}$ & $\frac{\frac{\mathrm{NO}_{3}}{(\mathrm{mg} / \mathrm{L}-}}{\underline{\mathrm{N}}}$ & $\frac{\frac{\mathrm{TP}}{(\mathrm{mg} / \mathrm{L}-}}{\underline{\mathrm{P})}}$ & $\underline{\underline{(\mathrm{mg} / \mathrm{Cl})}}$ \\
\hline B_C_Airport & $6 / 10 / 14$ & $8: 44$ & $<0.125$ & 8.33 & 19.5 & 639 & 8 & 87.15 & 2.84 & 1.03 & 8.27 & 0.0402 & 1.23 & 25.9 & 96.51 \\
\hline B_C_GE & $6 / 10 / 14$ & $9: 45$ & $<.25$ & 7.7 & 18.8 & 254.3 & 7.49 & 80.45 & 0.99 & 0.59 & 11.9 & 0.0895 & 1.4 & 35.7 & 43.91 \\
\hline B_C_Vernon & $6 / 10 / 14$ & $10: 59$ & $<0.125$ & 7.84 & 18.1 & 211.1 & 8.66 & 91.64 & & 1.32 & 7.31 & 0.029 & 0.961 & 33.6 & 25.42 \\
\hline B_H_Airport & $6 / 10 / 14$ & $8: 50$ & 1.0 & 7.7 & 17.1 & 504.7 & 8.04 & 83.4 & 10.29 & 2.56 & 11.8 & 0.0739 & 0.73 & 45.1 & 78.74 \\
\hline B_H_Cott & $6 / 10 / 14$ & $12: 53$ & $<0.125$ & 7.78 & 17.8 & 465.8 & 7.53 & 79.18 & 28.91 & 9.97 & 13.3 & 0.0216 & 3.58 & 54.3 & 51.64 \\
\hline B_H_EW & $6 / 10 / 14$ & $12: 03$ & 0.25 & 7.63 & 17.7 & 604 & 8.32 & 87.3 & 5.21 & 2.60 & 17 & 0.0509 & 0.762 & 28.3 & 130.60 \\
\hline B_H_GE & $6 / 10 / 14$ & $9: 34$ & 1.25 & 7.56 & 17.2 & 3661.1 & 8.09 & 84.1 & & 1.80 & 82.2 & 0.0227 & 0.681 & 56.8 & 44.09 \\
\hline B_H_GEAir & $6 / 10 / 14$ & $8: 35$ & 3.0 & 8.14 & 22.1 & 585 & 8.31 & 95.19 & 8.78 & 4.85 & 103 & 0.356 & 2.06 & 150 & 109.31 \\
\hline B_H_Jersey & $6 / 10 / 14$ & $11: 37$ & $<.25$ & 7.49 & 17.5 & 755 & 7.8 & 81.5 & 5.54 & 2.36 & 14.8 & 0.0363 & 0.457 & 40 & 171.42 \\
\hline B_H_Rowe & $6 / 10 / 14$ & $11: 49$ & 1 & 7.64 & 18.2 & 497.1 & 7.94 & 84.2 & 6.50 & 2.75 & 12.8 & 0.0276 & 1.43 & 57.2 & 77.49 \\
\hline B_H_Tipton & $6 / 10 / 14$ & $10: 23$ & 1.3 & 7.75 & 21.1 & 491.8 & 5.84 & 65.62 & 3.34 & 2.16 & 11.1 & 0.177 & 0.473 & 26.7 & 78.68 \\
\hline B_H_Vet & $6 / 10 / 14$ & $11: 11$ & 0.75 & 7.61 & 18.3 & 497.5 & 7.48 & 79.49 & 4.07 & 1.30 & 10.09 & 0.0146 & 0.222 & 19.2 & 95.02 \\
\hline B_ISC_EW & $6 / 10 / 14$ & $12: 15$ & 0.75 & 7.55 & 14.6 & 881 & 10.06 & 98.92 & 1.84 & 1.05 & 97.9 & 0.0233 & 0.709 & 21.1 & 72.94 \\
\hline B_L_GE & $6 / 10 / 14$ & 9:59 & 1.0 & 7.93 & 18 & 846 & 8.58 & 90.6 & 5.23 & 2.11 & 1.79 & 0.0175 & 0.131 & 29.9 & 171.26 \\
\hline B_R_Airport & $6 / 10 / 14$ & $8: 30$ & 0.25 & 7.97 & 18.8 & 617 & 7.39 & 79.38 & 19.66 & 5.41 & 8.86 & 0.0458 & 1.82 & 25.4 & 112.05 \\
\hline B_R_Cott & $6 / 10 / 14$ & $12: 42$ & 0.5 & 7.8 & 17.7 & 1418 & 8.77 & 92.03 & 40.14 & 9.71 & 17.9 & 0.0204 & 0.936 & 35.7 & 233.51 \\
\hline B_R_Emer & $6 / 10 / 14$ & $12: 28$ & & 7.7 & 18.2 & 1227 & 8.36 & 88.65 & 24.26 & 9.54 & 4 & 0.123 & 0.733 & 80.8 & 279.50 \\
\hline $\begin{array}{l}\text { B_R_Vet } \\
\text { DUP_ }\end{array}$ & $6 / 10 / 14$ & $11: 18$ & $<0.25$ & 7.53 & 18.1 & 813 & 8.91 & 94.29 & 22.83 & 9.89 & & 0.114 & 0.712 & 20.2 & 144.42 \\
\hline B_R_Emer & $6 / 10 / 14$ & $12: 28$ & & & & & & & 22.95 & 8.88 & 12.1 & 0.0232 & 0.942 & 23.1 & 292.31 \\
\hline $\begin{array}{l}\text { DUP_ } \\
\text { B_R_Vet }\end{array}$ & $6 / 10 / 14$ & $11: 18$ & & & & & & & 17.52 & 8.38 & 14.8 & 0.0612 & 1.36 & 134 & 186.10 \\
\hline
\end{tabular}




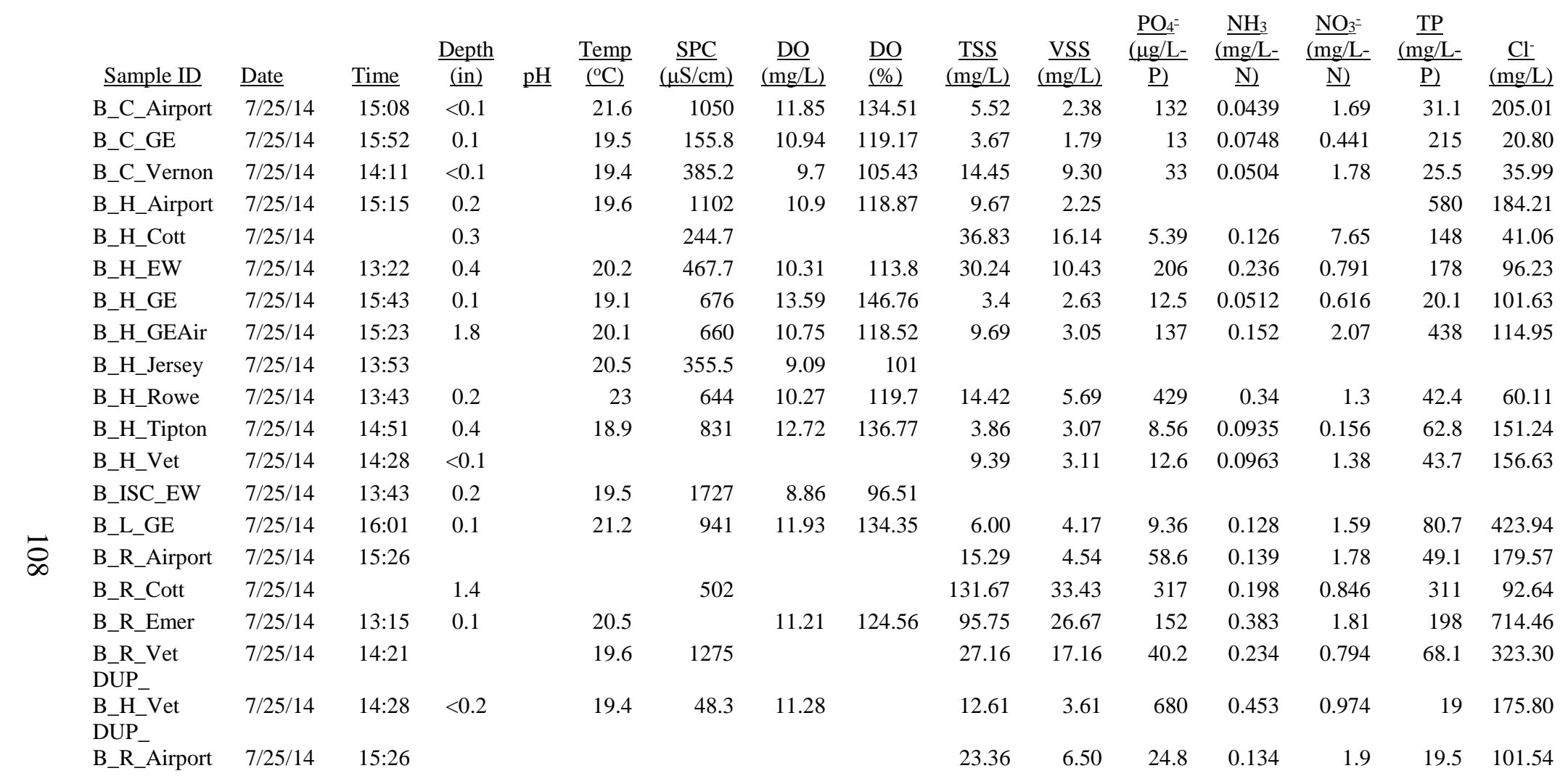




\begin{tabular}{|c|c|c|c|c|c|c|c|c|c|c|c|c|c|c|c|}
\hline$\underline{\text { Sample ID }}$ & Date & Time & $\frac{\text { Depth }}{\text { (in) }}$ & $\mathrm{pH}$ & $\frac{\text { Temp }}{\frac{\left({ }^{\circ} \mathrm{C}\right)}{}}$ & $\frac{\mathrm{SPC}}{(\mu \mathrm{S} / \mathrm{cm})}$ & $\frac{\mathrm{DO}}{(\mathrm{mg} / \mathrm{L})}$ & $\frac{\mathrm{DO}}{(\%)}$ & $\frac{\mathrm{TSS}}{(\mathrm{mg} / \mathrm{L})}$ & $\frac{\mathrm{VSS}}{(\mathrm{mg} / \mathrm{L})}$ & $\begin{array}{l}\frac{\mathrm{PO}_{4}=}{(\mu \mathrm{g} / \mathrm{L}} \\
\underline{-\mathrm{P})}\end{array}$ & $\frac{\frac{\mathrm{NH}_{3}}{(\mathrm{mg} / \mathrm{L}}}{\underline{-\mathrm{N})}}$ & $\frac{\frac{\mathrm{NO}_{3}}{(\mathrm{mg} / \mathrm{L}}}{-\underline{\mathrm{N})}}$ & $\frac{\frac{\mathrm{TP}}{(\mathrm{mg} /}}{\underline{\mathrm{L}-\mathrm{P})}}$ & $\frac{\mathrm{Cl}^{-}}{(\mathrm{mg} / \mathrm{L})}$ \\
\hline B_C_Airport & $9 / 14 / 14$ & 10:05 & 0.2 & 7.87 & 16.1 & 125.5 & 9.58 & 97.26 & 3.00 & 1.26 & 6.93 & 0.289 & 1.2 & 38.2 & 23.70 \\
\hline $\begin{array}{l}\text { B_C_CE } \\
\text { B_C_Verno }\end{array}$ & $9 / 14 / 14$ & $11: 10$ & 0.3 & 7.99 & 15.2 & 1036 & 9.06 & 90.24 & 1.22 & 1.01 & 31.9 & 0.107 & 0.269 & 37.8 & 21.05 \\
\hline $\begin{array}{l}\text { n } \\
\text { B_H_Airpor }\end{array}$ & $9 / 14 / 14$ & $11: 24$ & 0.1 & 7.77 & 17.2 & 156 & 7.7 & 80.04 & 1.94 & 1.47 & 36 & 0.0229 & 0.649 & 32.4 & 17.81 \\
\hline $\mathrm{t}$ & 9/14/14 & 10:00 & 1 & 7.67 & 16.2 & 243.6 & 8.59 & 87.39 & 31.75 & 7.64 & 104 & 0.135 & 0.635 & 87.8 & 41.43 \\
\hline B_H_Cott & $9 / 14 / 14$ & $12: 55$ & 0.1 & 8.25 & 17.3 & 163 & 8.15 & 84.9 & 12.15 & 3.53 & 167 & 0.0584 & 0.873 & 181 & 20.95 \\
\hline B_H_EW & $9 / 14 / 14$ & $12: 20$ & 0.4 & 8.72 & 16.6 & 135.5 & 9.41 & 96.51 & 11.16 & 4.23 & 68.8 & 0.0851 & 0.336 & 70.8 & 27.12 \\
\hline B_H_GE & $9 / 14 / 14$ & $9: 25$ & 0.9 & 8.72 & 15.3 & 59.7 & 8.8 & 87.82 & 19.45 & 5.62 & 67.8 & 0.161 & 0.337 & 68.1 & 78.16 \\
\hline B_H_GEAir & $9 / 14 / 14$ & $10: 12$ & 6 & 7.7 & 17 & 290.6 & 8.94 & 92.55 & 5.95 & 2.14 & 88.7 & 0.0633 & 0.326 & 95.9 & 52.04 \\
\hline B_H_Jersey & $9 / 14 / 14$ & $11: 50$ & 1 & 9.7 & 16.2 & 1466.9 & 7.71 & 78.43 & 158.18 & 12.95 & & & & 25.6 & 67.62 \\
\hline B_H_Rowe & $9 / 14 / 14$ & $12: 03$ & 3 & 9.26 & 16.3 & 109 & 8.8 & 89.7 & 4.79 & 1.66 & 91.5 & 0.0781 & 0.348 & 91.3 & 22.26 \\
\hline B_H_Tipton & $9 / 14 / 14$ & $10: 30$ & 3 & 7.62 & 16.7 & 461.5 & 6.77 & 69.58 & 12.48 & 4.63 & 24.6 & 0.272 & 0.922 & 48.3 & 51.59 \\
\hline B_H_Vet & $9 / 14 / 14$ & $11: 36$ & 0.1 & 7.62 & 17.7 & 601 & 7.98 & 83.74 & 11.84 & 2.47 & 76.1 & 0.0882 & 0.545 & 59.4 & 130.01 \\
\hline B_ISC_EW & $9 / 14 / 14$ & $12: 27$ & 0.2 & 8.33 & 16 & 268.5 & 8.94 & 90.58 & 65.14 & 16.29 & 214 & 0.192 & 0.786 & 270 & 26.74 \\
\hline B_L_GE & $9 / 14 / 14$ & 10:45 & 3 & 8.07 & 15.6 & 175.4 & 8.07 & 81.11 & 15.97 & 4.42 & 109 & 0.0769 & 0.325 & 133 & 32.93 \\
\hline B_R_Airport & $9 / 14 / 14$ & 10:10 & 2.5 & 7.95 & 16.3 & 115.9 & 8.93 & 91.03 & 24.24 & 5.44 & 86.2 & 0.0552 & 0.295 & 98.5 & 23.79 \\
\hline B_R_Cott & $9 / 14 / 14$ & $12: 49$ & 0.8 & 8.24 & 16.6 & 568 & 8.3 & 85.13 & 38.93 & 10.53 & 37.3 & 0.0846 & 0.321 & 61.5 & 98.00 \\
\hline B_R_Emer & $9 / 14 / 14$ & $12: 37$ & 0.9 & 8.35 & 17.5 & 155.2 & 8.73 & 91.22 & 34.48 & 11.61 & 77.4 & 0.0588 & 0.287 & 105 & 28.73 \\
\hline $\begin{array}{l}\text { B_R_Vet } \\
\text { DUP_ }\end{array}$ & $9 / 14 / 14$ & $11: 30$ & 0.1 & 7.43 & 17.7 & 891 & 8.83 & 92.65 & 4.26 & 1.58 & 12.4 & 0.101 & 0.963 & 13.6 & 183.27 \\
\hline $\begin{array}{l}\text { B_H_Jersey } \\
\text { DUP_ }\end{array}$ & $9 / 14 / 14$ & $11: 50$ & 1 & 9.7 & 16.2 & 1466.9 & 7.71 & 78.43 & 128.93 & 13.03 & 1.72 & 0.29 & 1.19 & 51.7 & 67.64 \\
\hline B_H_Tipton & $9 / 14 / 14$ & $10: 30$ & 3 & 7.62 & 16.7 & 461.5 & 6.77 & 69.58 & 6.66 & 1.96 & 26.6 & 0.269 & & 61 & 23.88 \\
\hline
\end{tabular}




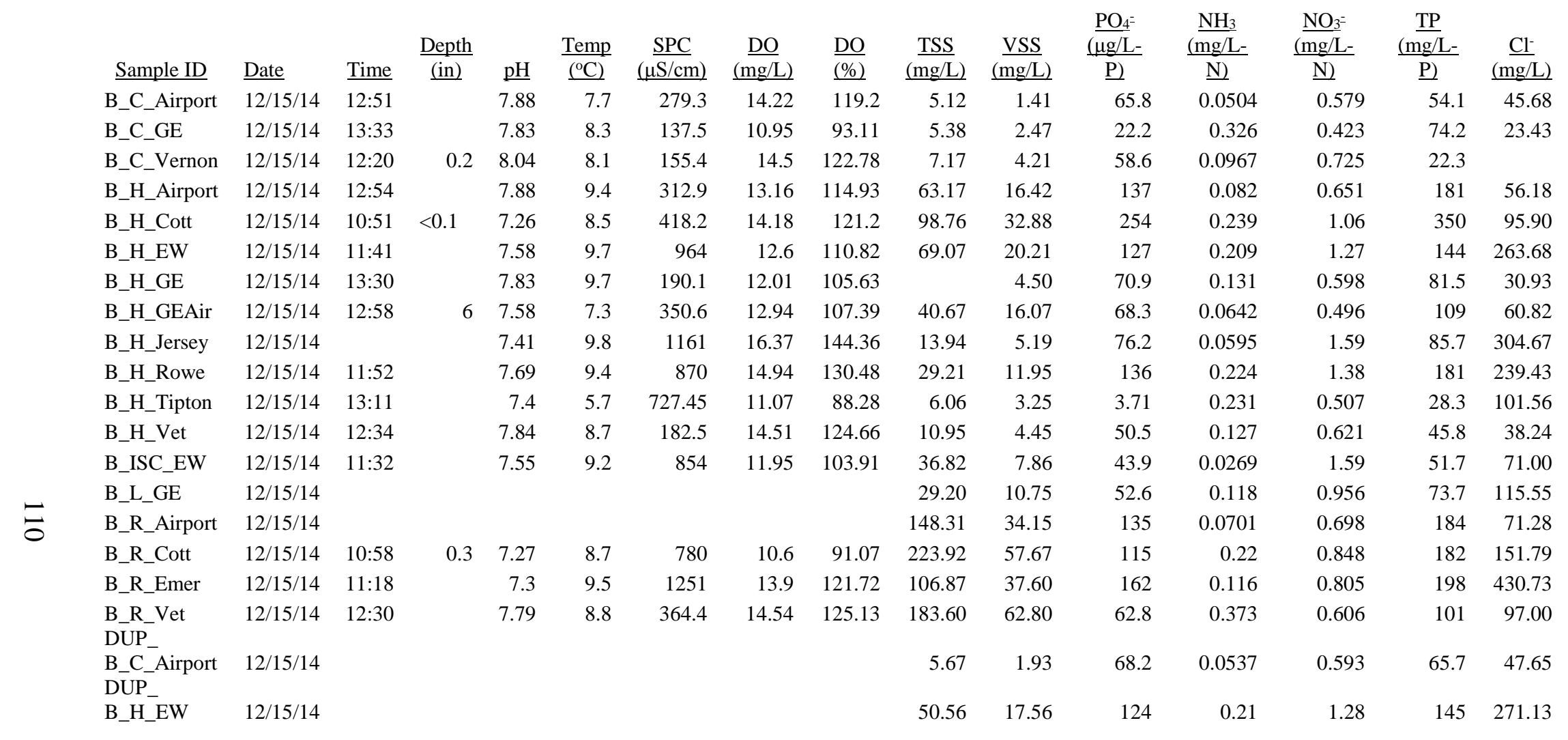




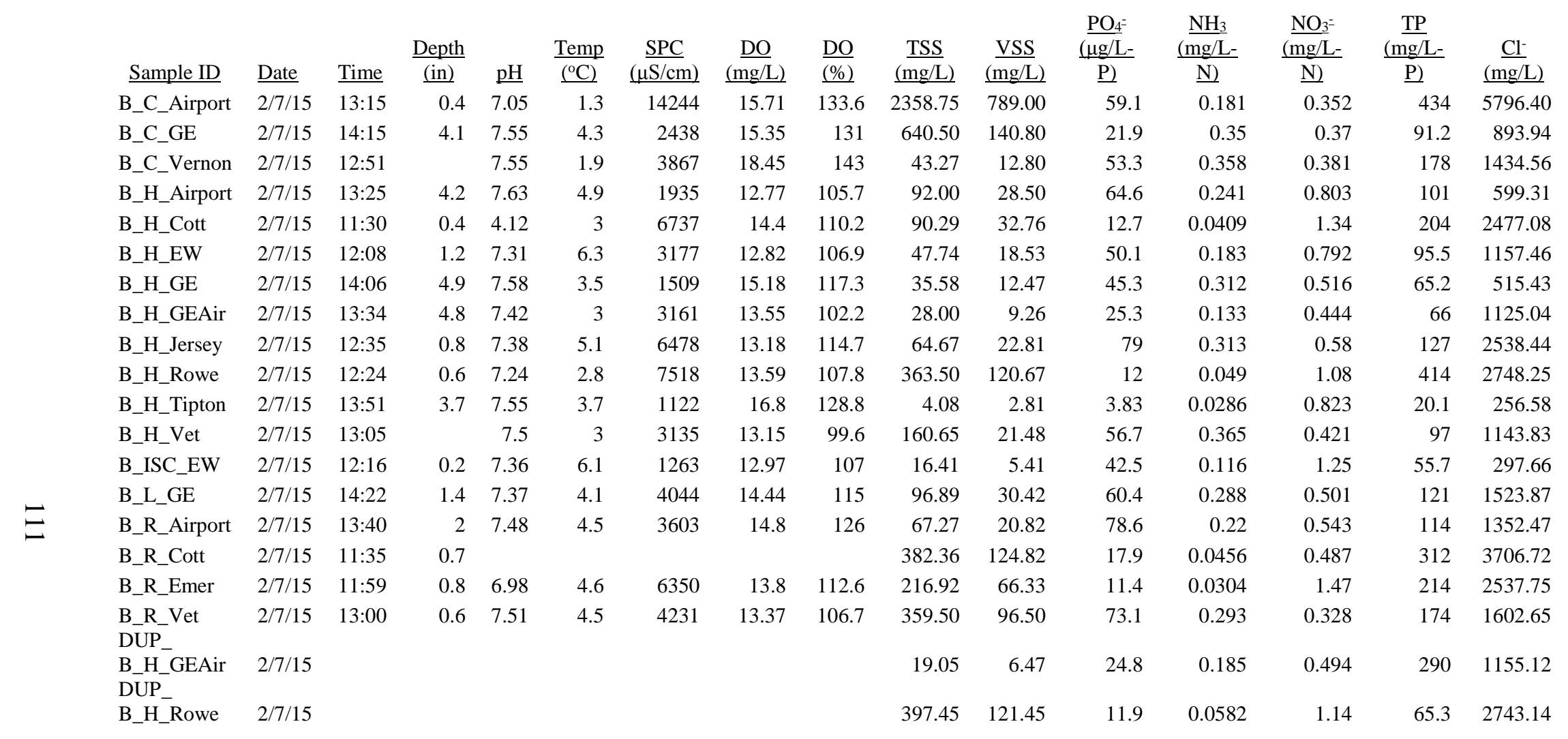

